\title{
Extração sequencial na interpretação das concentrações de elementos traços nos sedimentos do reservatório Guarapiranga São Paulo - SP
}

\author{
CÍNTIA MOREIRA MARCILIANO DA COSTA
}

Dissertação apresentada como parte dos requisitos para obtenção do Grau de Mestre em Ciências na Área de Tecnologia Nuclear - Materiais

Orientadora:

Profa. Dra. Maria Aparecida Faustino Pires

Coorientadora:

Profa. Dra. Marycel Elena Barboza Cotrim

São Paulo 
INSTITUTO DE PESQUISAS ENERGÉTICAS E NUCLEARES Autarquia associada à Universidade de São Paulo

Extração sequencial na interpretação das concentrações de elementos traços nos sedimentos do reservatório Guarapiranga, São Paulo - SP

\author{
CÍNTIA MOREIRA MARCILIANO DA COSTA \\ Dissertação apresentada como parte dos \\ requisitos para obtenção do Grau de Mestre em \\ Ciências na Área de Tecnologia Nuclear - \\ Materiais \\ Orientadora: \\ Profa. Dra. Maria Aparecida Faustino Pires \\ Coorientadora: \\ Profa. Dra. Marycel Elena Barboza Cotrim
}

Versão Corrigida

Versão Original disponível no IPEN

São Paulo 
Ao meu pai Roldão in memoriam, À minha mãe Beatriz, meu alicerce e meu porto seguro, Ao Renato, por sempre estar ao meu lado. 


\section{AGRADECIMENTOS}

Durante este percurso foram muitos os obstáculos, que em muitos momentos duvidei que conseguiria concluir esta dissertação. Mas, graças a Deus e ao apoio de pessoas fantásticas foi possível a conclusão deste trabalho.

Agradeço,

À Dra. Maria Aparecia Faustino Pires, pela orientação, paciência, incentivo, confiança e pela oportunidade de fazer parte deste projeto de pesquisa.

À Dra. Marycel Elena Barboza Cotrim, por toda contribuição para conclusão deste trabalho.

À MSc. Luciana Vieira Santana, que me acompanha desde 2012 no IPEN, uma amiga que eu ganhei, que sempre me incentivou e me ajudou muito, principalmente nesta reta final.

À MSc. Sabine Neusatz Guilhen, muito obrigada, seus conselhos foram fundamentais para a conclusão desta etapa, além é claro, muito obrigada pela ajuda com o ICPOES.

Ao Dr. João Cristiano Ulrich, um profissional exímio, muito obrigada por todo ensinamento e ajuda.

À Dra. Nilce Ortiz, pelas aulas, conselhos valorosos, e principalmente pelo carinho e amizade.

Às amigas que o IPEN me deu, Daphne e Tania, muito obrigada por todo apoio, sugestões e ombro amigo.

Ao Elias e à Martinha que sempre que precisei da Central, eles estavam lá para me ajudar.

Aos funcionários e alunos do CQMA, muito obrigada por toda ajuda técnica e convivência. 
Ao Instituto de Pesquisas Energéticas e Nucleares (IPEN/CNEN-SP) e ao Centro de Química e Meio Ambiente (CQMA) pela infraestrutura necessária para a conclusão deste trabalho.

À minha mãe e ao Renato, que nos momentos difíceis desse trabalho, me fizeram acreditar que tudo daria certo.

À minha queridíssima amiga Eng. Cláudia Bittencourt, incrível como nossos caminhos se cruzam! Muito obrigada pela amizade, pelo carinho e pelas sugestões não só para conclusão deste trabalho, mas também para que eu me torne uma pessoa melhor.

Foram tantas as pessoas que me ajudaram durante esta jornada, que eu só tenho a agradecer por todo apoio e carinho.

Muito obrigada! 


\title{
EXTRAÇÃO SEQUENCIAL NA INTERPRETAÇÃO DAS CONCENTRAÇÕES DE ELEMENTOS TRAÇOS NO SEDIMENTO DO RESERVATÓRIO GUARAPIRANGA, SÃO PAULO - SP
}

\author{
Cíntia Moreira Marciliano da Costa
}

\begin{abstract}
RESUMO
Os contaminantes lançados no ambiente decorrente das atividades humanas podem se movimentar de um compartimento ambiental para o outro e assim chegar nos corpos hídricos, onde se associam rapidamente ao material particulado e incorporam-se aos sedimentos. Desta forma, a relação água com o sedimento faz deste compartimento um dos principais alvos de preocupação e análise, dada sua importância na ciclagem de matéria e na biodisponibilidade de diversos compostos químicos para o ambiente aquático. O objetivo deste trabalho foi avaliar o comportamento geoquímico dos elementos $\mathrm{Al}, \mathrm{Fe}, \mathrm{Cr}, \mathrm{Cu}, \mathrm{Zn}, \mathrm{Mn}$, e $\mathrm{P}$ em sedimento superficial do reservatório Guarapiranga por meio da técnica de extração sequencial constituída de quatro etapas, seguido pela detecção em espectrometria de emissão ótica com plasma acoplado indutivamente (ICP-OES). Foram coletadas amostras de sedimento superficial em 14 (quatorze) estações estrategicamente escolhidas, de modo a conhecer a heterogeneidade do sistema e determinar a mobilidade de elementos-traço persistentes e sua distribuição espacial no compartimento sedimentar da represa. As amostras passaram por processo de secagem e foi separada a fração silte/argila. A extração sequencial foi realizada em quatro etapas, a fração 1 ácido solúvel ligada a carbonatos, a fração 2 redutível a óxidos de ferro e manganês, a fração 3 oxidável ligada a matéria orgânica e a fração 4 residual. Todo o processo foi feito em triplicata e as concentrações dos elementos foram determinadas no ICP-OES. Com base nos resultados obtidos da extração sequencial, foi possível avaliar a distribuição dos elementos nas quatro frações geoquímicas distintas bem como o fator de mobilidade individual e total desses elementos no reservatório. A soma das três primeiras frações compõe a fração
\end{abstract}


considerada biodisponível enquanto que a diferença do total extraído representou a fração residual. A partir dos resultados obtidos infere-se que o reservatório do Guarapiranga apresenta dois compartimentos distintos, um mais degradado que vai do ponto GU-05 ao GU-14 que sofre os impactos da ocupação do seu entorno e um mais preservado que vai do ponto GU-01 a GU-04, com pouca influência de ocupação urbana no seu entorno. O grau de mobilidade global segue uma tendência de montante à jusante do reservatório, próxima a barragem.

Palavras-Chave: Biodisponibilidade, elementos traço, sedimentos, Guarapiranga 


\title{
SEQUENTIAL EXTRACTION IN THE INTERPRETATION OF CONCETRATIONS OF TRACE ELEMENTS IN SEDIMENTS AT THE GUARAPIRANGA RESERVOIR, SÃO PAULO - SP
}

Cíntia Moreira Marciliano da Costa

\begin{abstract}
The contaminants produced by human activities released in the environment may move from one environmental compartment to another and reach the water bodies, where they rapidly associate to particulate matter and are incorporated to the sediments. Thus, the relationship between water and sediment makes this compartment on of the main targets for concern and analysis, given its importance in cycling matter and in bioavailability of various chemical compounds to the water environment. The objective of this work was to study the geochemical behaviour of the elements $\mathrm{Al}, \mathrm{Fe}, \mathrm{Cr}, \mathrm{Cu}, \mathrm{Zn}, \mathrm{Mn}$ and $\mathrm{P}$ in the surface sediments of the Guarapiranga reservoir $\left(23^{\circ} 47^{\prime} \mathrm{S}\right.$ and $\left.46^{\circ} 32^{\prime \prime} \mathrm{W}\right)$ by means of the sequential extraction technic consisting of four stages, followed by the detection in inductively coupled plasma optical emission spectroscopy (ICP-OES). Samples were collected from the superficial sediment in 14 (fourteen) stations strategically chosen, this way being able to know the heterogeneity of the system and to determinate the mobility of persistent trace elements and their spatial distribution in the sedimentary compartment of the reservoir. The samples were subjected to a drying process and then separating the silt fraction. The sequential extraction was made in four steps, fraction 1 acid soluble linked to carbonates, fraction 2 reducible to iron and manganese oxides, fraction 3 oxidable linked to organic matter and fraction 4 residual. All the process was done in triplicate and the concentration of the elements was determined by ICP-OES. Based on the results obtained by the sequential extraction, it was possible to evaluate the distribution of the elements in the four distinct geochemical fractions, as well as the individual mobility factor of those elements in the reservoir. The sum of the first three fractions composes the fraction considered bioavailable, while the difference from the total extracted represented the residual fraction. Parting from the results obtained it is
\end{abstract}


inferred that the Guarapiranga reservoir has two distinct compartments, one more degraded that goes from point GU-05 to GU-14 that suffers from the impacts of the occupations in the surroundings and one more preserved that goes from point GU-01 to GU-04, with little influence from urban occupation in the surroundings. The degree of global mobility follows the tendency of up and down stream in the reservoir, next to the barrage.

Keywords: Bioavailability, trace elements, sediments, Guarapiranga 


\section{LISTA DE FIGURAS}

Figura 1 Localização da Bacia do Guarapiranga na Bacia do Alto Tietê e 27 municípios de abrangência.

Figura 2 (a) Localização do Estado de São Paulo no Brasil, (b) 28 localização da represa Guarapiranga na Região Metropolitana de São Paulo (RMSP) e (c) represa Guarapiranga.

Figura 3 Represa Guarapiranga e seus tributários

Figura 4 Estação de bombeamento do braço Taquacetuba da Billings 31 para o reservatório Guarapiranga.

Figura 5 Mapa de uso e cobertura da terra da Bacia do Guarapiranga no ano de 1986. Os domínios (números) assinalam áreas de maior concentração urbana na bacia.

Figura 6 Uso e ocupação da terra na região onde se localiza a represa 36 Guarapiranga no Estado de São Paulo no ano de 2002 (A) e o ano de 2014 (B).

Figura 7 Mapa de cobertura e uso da terra na Bacia da represa 37 Guarapiranga.

Figura 8 Reservatório Guarapiranga Desembocadura do córrego 38 Guavirutuba com expressivo aglomerado urbano e área de eutrofização.

Figura 9 Reservatório Guarapiranga, região a montante com áreas 39 preservadas.

Figura 10 Reservatório Guarapiranga, região próxima à barragem com 39 intensa ocupação por residências e assentamentos clandestinos.

Figura 11 Espectrômetro de Emissão Óptica com Plasma de Argônio (ICP- 40 OES) (SPECTRO ARCOS)

Figura 12 Mapa dos pontos de coleta do reservatório do Guarapiranga. 43

Figura 13 Amostragem de sedimento e amostrador de sedimento tubular 45 de gravidade (tipo Kajak) em detalhe.

Figura 14 Distribuição espacial das concentrações "pseudototal" de Fe e 51 Al presentes no sedimento superficial, ao longo dos pontos de coleta no reservatório Guarapiranga. 
Figura 15 Distribuição espacial das concentrações "pseudototal" de Zn e 52 $\mathrm{Cr}$ presentes no sedimento superficial, ao longo dos pontos de coleta no reservatório Guarapiranga.

Figura 16 Distribuição espacial das concentrações "pseudototal" de Cu e 53 Mn presentes no sedimento superficial, ao longo dos pontos de coleta no reservatório Guarapiranga.

Figura 17 Distribuição espacial das concentrações "pseudototal" de 54 Fósforo presentes no sedimento superficial, ao longo dos pontos de coleta no reservatório Guarapiranga.

Figura 18 Distribuição percentual de Fe nas principais frações (F1, F2, F3 62 e F4) nos sedimentos superficiais amostrados no reservatório Guarapiranga.

Figura 19 Distribuição de Al nas principais frações (F1, F2, F3 e F4) nos 64 sedimentos superficiais amostrados no reservatório Guarapiranga.

Figura 20 Distribuição de Zn nas principais frações (F1, F2, F3 e F4) nos 66 sedimentos superficiais amostrados no reservatório Guarapiranga.

Figura 21 Distribuição de Cr nas principais frações (F1, F2, F3 e F4) nos sedimentos superficiais amostrados no reservatório Guarapiranga.

Figura 22 Distribuição de Cu nas principais frações (F1, F2, F3 e F4) nos sedimentos superficiais amostrados no reservatório Guarapiranga.

Figura 23 Distribuição de Mn nas principais frações (F1, F2, F3 e F4) nos sedimentos superficiais amostrados no reservatório Guarapiranga.

Figura 24 Distribuição de $P$ nas principais frações (F1, F2, F3 e F4) nos 72 sedimentos superficiais amostrados no reservatório Guarapiranga.

Figura 25 Concentração em Porcentagem das frações biodisponíveis e 75 residuais obtidas nos pontos de coleta para o elemento Fe.

Figura 26 Concentração em Porcentagem das frações biodisponíveis e 76 residuais obtidas nos pontos de coleta para o elemento Al.

Figura 27 Concentração em Porcentagem das frações biodisponíveis e 76 residuais obtidas nos pontos de coleta para o elemento $\mathrm{Zn}$. 
Figura 28 Concentração em Porcentagem das frações biodisponíveis e 77 residuais obtidas nos pontos de coleta para o elemento $\mathrm{Cr}$.

Figura 29 Concentração em Porcentagem das frações biodisponíveis e 78 residuais obtidas nos pontos de coleta para o elemento $\mathrm{Cu}$.

Figura 30 Concentração em Porcentagem das frações biodisponíveis e 79 residuais obtidas nos pontos de coleta para o elemento $\mathrm{Mn}$.

Figura 31 Concentração em Porcentagem das frações biodisponíveis e 80 residuais obtidas nos pontos de coleta para o elemento $P$.

Figura 32 Concentração de $\mathrm{Cu}$ no sedimento dos 14 pontos de 82 amostragem no Reservatório Guarapiranga e Valores - Guia de Qualidade de Sedimento (TEL e PEL).

Figura 33 Concentração de $\mathrm{Cr}$ no sedimento dos 14 pontos de 83 amostragem no Reservatório Guarapiranga e Valores - Guia de Qualidade de Sedimento (TEL e PEL).

Figura 34 Concentração de Zn no sedimento dos 14 pontos de 85 amostragem no Reservatório Guarapiranga e Valores - Guia de Qualidade de Sedimento (TEL e PEL).

Figura 35 Representação gráfica do fator de mobilidade individual $\left(M_{f}^{i}\right)$ para os elementos $\mathrm{Fe}, \mathrm{Al}, \mathrm{Zn}, \mathrm{Cr}, \mathrm{Cu}, \mathrm{Mn}$ e $\mathrm{P}$ e fator de mobilidade global $\left(M_{f}\right)$ no reservatório. 


\section{LISTA DE TABELAS}

Tabela 1 Valores Guias estabelecidos pelo Canadian Council of Ministers of the Environment.

Tabela 2 Municípios inseridos na Bacia da Guarapiranga.

Tabela 3 Evolução da população - Guarapiranga e Billings 1980/2006.

Tabela 4 Descrição dos pontos de coleta de amostras de sedimento e coordenadas geográficas do reservatório da Guarapiranga

Tabela 5 Programa de aquecimento do forno micro-ondas para amostras de sedimento.

Tabela 6 Protocolo analítico da extração sequencial modificado (Asharaf, 2012).

Tabela 7 Condições Operacionais do ICP-OES

Tabela 8 Concentração dos metais Fe, Al, Zn, Cr, Cu, Mn e do P obtidos nas amostras de sedimentos pelo método de extração sequencial (média de três determinações).

Tabela 9 Fator de mobilidade individual $\left(M_{f}^{i}\right)$ e fator de mobilidade global $\left(M_{f}\right)$ 


\section{SUMÁRIO}

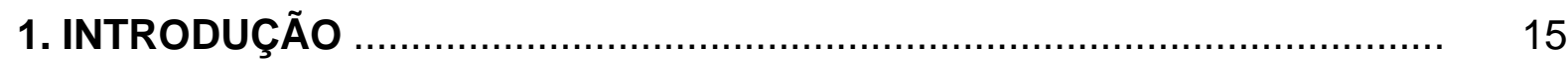

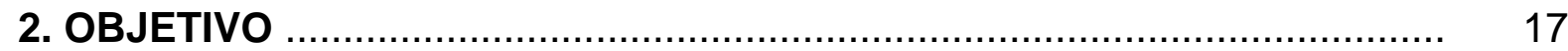

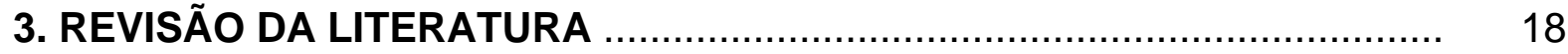

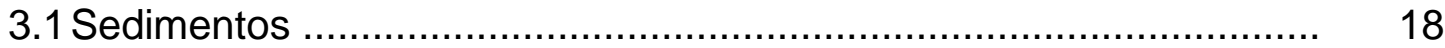

3.1.1 Metais em sedimentos ......................................... 21

3.2 Valores Guias de Qualidade de Sedimento (VGQS) ..................... 22

3.3 Extração sequencial .............................................................. 24

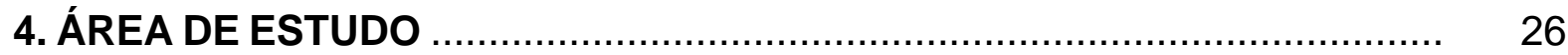

4.1Represa Guarapiranga ................................................ 26

4.2 Uso e ocupação do solo no entorno da Represa Guarapiranga ......... 31

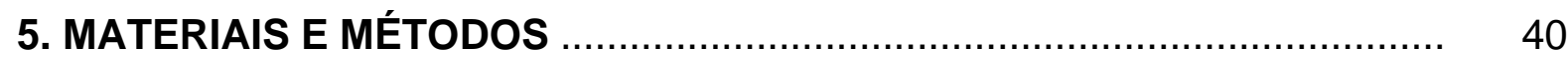

5.1 Materiais e Equipamentos...................................................... 40

5.2 Reagentes e Soluções ..................................................... 41

5.3 Coleta e preparo das amostras........................................... 41

5.4 Extração sequencial ............................................................... 46

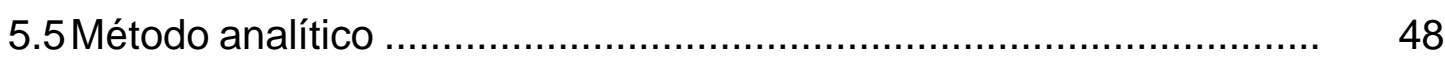

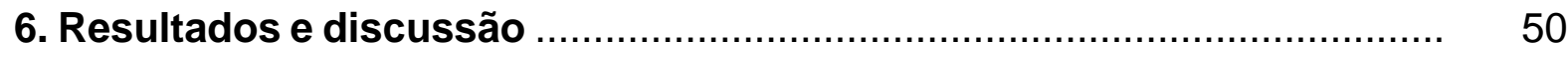

6.1Concentração, distribuição e disponibilidade dos metais Fe, Al, Zn, $\mathrm{Cr}, \mathrm{Cu}$ e Mn e do elemento Fósforo nas frações do sedimento 
6.3 Concentração de Metais no Sedimento segundo os Valores Guia de Qualidade de Sedimento - VGQS 


\section{INTRODUÇÃO}

A organização do espaço sempre foi um problema nos grandes centros urbanos. O crescente desenvolvimento urbano e o aumento da população resultaram em severos danos ambientais.

A preocupação sobre os impactos produzidos pelo homem em centros urbanos tornou-se mais evidente nos últimos anos, o homem sempre buscou seu desenvolvimento sobre bacias hidrográficas, já que suas águas são essenciais para manutenção da vida e fontes de funcionamento para todas as atividades humanas. Assim, ao longo dos anos tem-se verificado, o reflexo da expansão acelerada e desordenada.

Dentre os contaminantes produzidos pelas atividades humanas, os metais têm contribuído de forma significativa no ambiente, interferindo temporária ou permanentemente na manutenção da biota terrestre e aquática.

Uma vez lançados ao ambiente, os contaminantes podem se movimentar de um compartimento ambiental para outro e, assim que atingem corpos hídricos associam-se rapidamente ao material particulado e rapidamente se incorporam aos sedimentos. Desta forma, a relação água com o sedimento faz deste compartimento um dos principais alvos de análise, dada sua importância na ciclagem de matéria e na biodisponibilidade de diversos compostos químicos para o ambiente aquático.

Localizado na região sudoeste da Região Metropolitana de São Paulo (RMSP), o reservatório Guarapiranga é o segundo maior sistema fornecedor de abastecimento de água potável para a população da RMSP, que é marcada pela complexidade de um ambiente urbano com ocupação e uso do solo desordenado e intenso além de alta densidade populacional (Richter et al, 2007; Andrade et al, 2015). A bacia contribuinte do Reservatório Guarapiranga localiza-se na Bacia do Alto Tietê (BAT) e abrange uma área de 61.150 hectares (Andrade et al, 2015).

A RMSP é composta por 39 municípios e possui uma população de mais de vinte milhões de habitantes (IBGE, 2015). A região é abastecida por oito sistemas produtores de água (Instituto Socioambiental, 2014a, 2014b), que são operados pela Companhia de Saneamento Básico do Estado de São Paulo (SABESP). A SABESP é 
uma sociedade anônima de economia mista fundada em 1973, atualmente é responsável pelo fornecimento de água e coleta e tratamento de esgotos de 367 municípios do Estado de São Paulo. É considerada uma das maiores empresas de saneamento do mundo em população atendida. São 27,7 milhões de pessoas abastecidas com água e 21,2 milhões de pessoas com coleta de esgotos (SABESP, 2017). Dentre os sistemas produtores de água, destacam-se o Sistema Cantareira, o Sistema Guarapiranga e o Sistema Alto Tietê (ANA, 2010).

O abastecimento de água potável para a RMSP vem enfrentando crescentes desafios nos últimos anos, devido principalmente ao crescimento da população e a falta de planejamento (Côrtes et al, 2015). A este quadro deve ser adicionado o fato do agravamento gradual dos problemas de poluição, influenciada pelas atividades antrópicas da região, pela urbanização descontrolada, lançamento de esgotos tratados e in natura, uso e ocupação do solo desordenado e pela industrialização da área (Richter et al, 2007; Tundisi, 2008; Arruda et al, 2016).

A mancha urbana da cidade está em constante crescimento em direção aos mananciais causando impactos negativos para a qualidade da água e contribuindo para a perda acelerada da capacidade de produção. As áreas já ocupadas e que têm infraestrutura são cada vez mais valorizadas e especuladas, inviabilizando a permanência da população mais pobre, que não pode arcar com os custos crescentes dos imóveis. Como resultado, novos terrenos e moradias de preço acessível tornamse disponíveis cada vez mais longe do centro, promovendo o avanço da área urbana e a consequente perda de áreas ainda protegidas (ISA, 2006).

As ações para prevenir o avanço da ocupação dos mananciais são tímidas e demoradas. Os raros investimentos nas áreas de mananciais são dedicados basicamente à realização de obras de infraestrutura e à recuperação de alguns assentamentos precários, essas obras são inexpressivas diante do ritmo do crescimento da população e dos assentamentos nessas regiões. Os mananciais já abrigam mais de $10 \%$ da área urbanizada e 18\% das áreas de favela de toda a Região Metropolitana, com uma população superior a 1,6 milhão de pessoas. Já a população que vive ao redor da represa do Guarapiranga aumentou em quase 40\%, entre 1991 e 2000 era estimada em aproximadamente 800 mil (ISA, 2006). Frequentemente são 
o registrados pela imprensa loteamentos clandestinos e invasões de grileiros nas áreas de mananciais às margens das Represas Billings e do Guarapiranga (Hisayasu et al., 2016).

Os sedimentos têm sido cada vez mais utilizados em estudos de avaliação da qualidade de ecossistemas aquáticos, por serem reconhecidamente acumuladores de informações de natureza biogeoquímica. Por meio de seu estudo é possível obter valiosas informações quanto aos contaminantes presentes no sistema fluvial. No entanto, a variação de fatores ambientais tem o potencial de alterar a capacidade de estocagem dos sedimentos ou a disponibilidade destes elementos estocados, fazendo com que haja forte acréscimo em sua dispersão no meio ambiente (Coringa, 2014).

O papel do sedimento na retenção ou disponibilização de elementos traço para o meio aquoso é determinado por meio da extração sequencial. O processo é realizado com o uso de reagentes específicos para cada fração química com o propósito de simular as variações ambientais a que estão sujeitos os sedimentos em seu ambiente de origem.

Sendo assim, a análise de sedimentos torna-se um indicador da qualidade de ambientes aquáticos e de todo o ecossistema. Desta forma, devido à importância na dinâmica do ecossistema aquático, além da qualidade da água, torna-se necessária a avaliação da qualidade do sedimento de forma abrangente, por meio de análises físico-químicas, químicas e toxicológicas, fornecendo dados sobre o grau de contaminação e os possíveis efeitos.

A proposta deste trabalho insere-se no Projeto Temático da FAPESP intitulado "Reconstrução paleolimnológica da represa Guarapiranga e diagnóstico da qualidade atual da água e dos sedimentos de mananciais da RMSP com vistas ao gerenciamento do abastecimento" (Processo Número: 2009/53898-9; Acrônimo: AcquaSed). O projeto visa reconstituir o histórico de eutrofização e impactos antropogênicos da represa, identificando os principais fatores desencadeadores do cenário atual, o qual conta com apoio da Sabesp no que se refere à logística de campo e fornecimento de dados secundários. 


\section{OBJETIVO}

O presente estudo teve como objetivo:

Mapear a qualidade dos sedimentos e suas implicações na manutenção da vida aquática e no abastecimento de água para consumo humano, aplicando método de extração sequencial nas amostras de sedimento superficial, seguida da determinação de metais e elementos traços por espectrometria de emissão ótica com plasma acoplado indutivamente (ICP-OES). 


\section{REVISÃO DA LITERATURA}

\subsection{Sedimentos}

Em ambientes aquáticos, é possível distinguir compartimentos abióticos que constantemente interagem entre si: o material particulado em suspensão (sedimento em suspensão), os sedimentos (sedimento depositado), as águas superficiais e as águas intersticiais (Passos, 2005).

Os materiais particulados em suspensão e os contaminantes em solução podem sofrer processos de adsorção/desorção e co-precipitação. Desta forma, o material em suspensão e o sedimento depositado se interligam por meio da sedimentação e processos erosivos. Entre os sedimentos de fundo e os poluentes da água intersticial ocorrem os processos de adsorção/desorção e de precipitação/dissolução. A elevada concentração desses elementos na água intersticial pode influenciar os seus níveis nas águas superficiais através de processos como difusão, consolidação e bioturvação (Passos, 2005 apud Salomons \& Forstner, 1984).

Um dos compartimentos aquáticos considerados mais importantes para a avaliação do nível de contaminação e de poluição desses ecossistemas, é o sedimento depositado. Este compartimento é formado por camadas de partículas orgânicas e inorgânicas com granulometria muito fina que cobrem o fundo dos rios, lagos, reservatórios, estuários e oceanos. Estas partículas compreendem diferentes materiais, e a proporção de materiais orgânicos e inorgânicos variam substancialmente em função do local (Passos, 2005). Esse compartimento funciona como um depósito de muitas substâncias químicas, especialmente metais tóxicos, elementos traços e compostos orgânicos (Otomo, 2015; Shihomatsu, 2015).

Nos ecossistemas aquáticos, tem sido verificado um aumento significativo na presença de metais de origem antrópica. Uma vez inseridos neste sistema, os metais se distribuem no material em suspensão, no sedimento de fundo e na água superficial. Todos esses compartimentos interagem entre si por processos de adsorção/desorção, precipitando, sedimentando e se difundindo por todo ambiente aquático (Lemes, 2001; Fontana et al., 2014). 
Os sedimentos têm valores agregados, esse compartimento é um dos principais componentes de um ecossistema aquático, ele forma diversos habitats para diferentes espécies, além de fornecer nutriente para estes organismos, e indiretamente para organismos de níveis tróficos mais elevados na cadeia alimentar. Desta forma, a qualidade dos sedimentos já é vista como uma extensão necessária para a proteção da qualidade aquática (Silvério, 2003; Fontana et al., 2014).

Conforme sua granulometria, os sedimentos podem ser classificados em dois grupos: finos (granulometria <50 <m) e grossos (> 50 $\mu \mathrm{m}$ ) (Passos, 2005 apud Salomons \& Forstner, 1984).

A sua capacidade em acumular compostos é o que faz dele tão importante. O sedimento é parte integrante de um complexo conjunto de ecossistemas aquáticos, uma vez que é responsável pelo transporte, liberação e acúmulo de compostos tóxicos e nutrientes, e pode representar uma fonte de contaminação do meio aquático (Mozeto, 2004; Fontana et al, 2014).

Tendo em vista que o transporte de sedimentos difere consideravelmente de um reservatório para outro, dependendo da secção transversal dos rios que formam o reservatório e do tipo de sedimento transportado (Tundisi \& Tundisi, 2008). Deste modo, existe uma imensa variação quanto a sua composição, que vai desde um mineral praticamente puro à predominância de matéria orgânica (Passos, 2005; Mozeto, 2004).

Os sedimentos depositados geralmente estão sob condições anaeróbias (redutoras), com certa quantidade de matéria orgânica e submetidos a constante lixiviação da coluna d’água. Sua grande capacidade de sorção e liberação de substâncias químicas faz deste compartimento um regulador de concentração de diversas espécies de substâncias em corpos hídricos, inclusive do $\mathrm{H}^{+}$, atuando como importante agente tamponante. O material em suspensão na coluna d'água precipita no fundo, fazendo deste compartimento um depósito de uma grande variedade de materiais (biológicos, químicos e poluentes). Existe uma grande preocupação quanto à transferência do material associado ao sedimento (principalmente poluentes) para os organismos que despendem boa parte do seu ciclo de vida em contato estreito com 
este compartimento cujos papéis na teia alimentar são de grande importância (Mozeto, 2004).

Reconhecidamente acumuladores de informações de natureza biogeoquímica, os sedimentos depositados podem ser considerados como a memória da bacia de drenagem na qual estão inseridos (Mozeto, 2004; Fontana et al, 2014).

O estudo do sedimento pode ser feito tanto com perfis sedimentares quanto com sedimentos superficiais. Os perfis representam sedimentos depositados em épocas distantes e, podem fornecer informações importantes sobre as características basais do ambiente aquático, auxiliando no estabelecimento de metas mais próximas da realidade, para a recuperação de ambientes impactados (Owens \& Walling, 2003). Já os sedimentos superficiais são as camadas superiores, mais recentes, que podem propiciar uma melhor forma de distinção entre as concentrações geogênicas e as antrópicas (CETESB, 2014).

Atualmente, o estudo do sedimento depositado tem sido utilizado para esclarecer importantes questões ambientais, como anomalias geoquímicas oriundas da poluição em ambientes diversos, incluindo o mecanismo de mobilização e desponibilização de elementos tóxicos nesses sedimentos (Rodrigues et al., 2015).

\subsubsection{Metais em sedimentos}

Os metais são compostos químicos que, em geral, são prejudiciais à biota. Sua distribuição no ambiente sob condições naturais ocorre de forma aleatória, mas generalizada, em toda a área. Podem ser encontrados em sedimentos de forma natural, proveniente da rocha matriz, ou por processos geoquímicos advindo do intemperismo, que são as fontes primárias de metais para o meio ambiente, sendo encontrados em diversas concentrações nas diferentes camadas superficiais em sedimentos e solos (Lopes, 2010).

Elementos como ferro, alumínio, manganês e estrôncio são em geral derivados de processos físicos e químicos tais como intemperismo e o carreamento de solo e rocha. Outra forma de inserção dos metais no ambiente, é a antrópica que nos últimos anos tem crescido drasticamente por meio de atividades industriais, 
agropastoris além do esgoto in natura que são descartados no dia-a-dia nos grandes centros urbanos (Otomo, 2015). Metais, especialmente metais-traço estão entre os contaminantes ambientais mais comuns e seu comportamento em diversos compartimentos ambientais merece destaque, principalmente por serem não degradáveis, permanecendo por longos períodos no ambiente, principalmente nos sedimentos e, portanto, representam ameaça potencial à biodiversidade bem como aos ecossistemas (Oliveira \& Marins, 2011)

A mobilização dos metais nos sedimentos, dependem da textura e da natureza química dos sedimentos. Estudos sugerem que a fração imobilizada é a não biodisponível e que a fração biodisponível é a concentração que pode ser assimilada pelos organismos vivos (Lopes, 2010).

Em sedimentos, a entrada de metais vem a partir de efluentes, tanto industriais quanto domésticos, que contêm uma grande variedade de constituintes além dos metais, como nutrientes e compostos orgânicos. Embora a indústria seja fonte destes elementos, metais como $\mathrm{Cu}, \mathrm{Zn}$, Fe, Co, Mn e Mo são, em geral relacionados ao descarte de esgoto in natura (Passos, 2005).

Os metais estão entre os poluentes mais preocupantes, e em sedimentos, podem estar presentes em diferentes formas: solúvel, trocável, ligado a matéria orgânica, ligado a óxidos/hidróxidos de ferro, alumínio e manganês, carbonatos, fosfatos, sulfatos (ou outros minerais secundários), ou ligados a silicatos (Devesa-Rey et al., 2010).

O estabelecimento da qualidade do sedimento deve ser baseado em um conjunto de informações e ações em complementação ao estabelecimento de backgrounds, como comparação com valores orientativos estabelecidos pela legislação e pesquisas com extração sequencial. 


\subsection{Valores Guias de Qualidade de Sedimento (VGQS)}

Devido à capacidade de os sedimentos atuarem como reservatório de contaminantes e desta forma agirem de forma negativa para o ambiente e para os organismos que vivem sob ou que estão em contato direto com este compartimento, foram estabelecidos os valores guia de qualidade de sedimento (VGQS).

Estes valores, foram desenvolvidos para classificar o grau de contaminação química dos sedimentos, são determinados segundo os valores guias estabelecidos pelo Canadian Council of Ministers of the Environment - CCME (CCME, 1999). VGQS baseiam-se na qualidade dos sedimentos quanto à presença de substâncias potencialmente tóxicas à biota, são importantes ferramentas para a análise da qualidade do sedimento, e são bastante empregados como valores orientadores da toxicidade de um ambiente (Padial, 2008).

De acordo com o CCME, as diretrizes ou VGQS são concentrações numéricas estabelecidas com o intuito de proteger a biota aquática, e todos envolvidos com o ciclo de vida aquático durante indefinido período de tempo de exposição a substâncias associadas ao sedimento (CCME, 1999).

Desta forma, essa legislação canadense estabelece os valores-guias de qualidade dos sedimentos, representados por dois valores: TEL (threshold effect level) - (nível de efeito limiar) e PEL (probable effect level) - (efeito provável). Os VGQS estão apresentados na Tabela 1.

O valor estabelecido para o TEL, refere-se ao menor limite, indica que concentrações que estão abaixo do limite estabelecido, raramente desenvolverão efeitos adversos para os organismos expostos. O valor estabelecido para o PEL, refere-se ao maior limite, ou seja, representa a concentração que acima da qual provavelmente ocorrerá efeito adverso aos organismos expostos. Entre os valores TEL e PEL existe uma zona de transição, na qual efeitos biológicos de toxicidade são incertos (CETESB, 2015).

Deste modo, é pertinente o desenvolvimento de diretrizes para avaliar a qualidade do sedimento, já que este compartimento exerce profunda influência na saúde dos organismos aquáticos. 
Tabela 1. Valores-guias estabelecidos pelo Canadian Council of Minister of the Environment.

\begin{tabular}{ccc}
\hline Variáveis & $\begin{array}{c}\text { TEL } \\
\left(\mathbf{m g ~ k g}^{-1}\right)\end{array}$ & $\begin{array}{c}\text { PEL } \\
\left(\mathbf{m g ~ k g}^{-1}\right)\end{array}$ \\
\hline Arsênio & 5,9 & 17 \\
Cádmio & 0,6 & 3,5 \\
Chumbo & 35 & 91,3 \\
Cobre & 35,7 & 197 \\
Cromo & 37,3 & 90 \\
Mercúrio & 0,17 & 00,486 \\
Níquel & 18,0 & 35,9 \\
Zinco & 123 & 315 \\
\hline
\end{tabular}

Fonte: CCME, 1999.

Vale ressaltar, que uma avaliação precisa do risco depende da correlação entre as concentrações desses contaminantes e a ocorrência dos efeitos causados à biota, baseada em informações químicas, físicas, biológicas e toxicológicas (Silva, 2016).

Até 2012, na legislação brasileira não existiam critérios para avaliar a qualidade dos sedimentos, deste modo, a CETESB adotava os valores TEL e PEL estabelecidos pela legislação Canadense. Com a Resolução CONAMA n454, os valores TEL e PEL são respectivamente Nível-1 e Nível-2 para água doce, adotados pela que estabelece as diretrizes para o gerenciamento do material a ser dragado em águas sob jurisdição nacional (CONAMA, 2012). 


\subsection{Extração Sequencial}

Vários procedimentos de extração sequencial foram desenvolvidos nos últimos anos. Os métodos de extração têm como princípio usar uma série de reagentes para solubilizar sucessivamente as diferentes substâncias existentes em uma matriz. Em geral, as substâncias capazes de extrair os elementos químicos de uma matriz são eletrólitos inertes, ácidos fracos, agentes redutores e agentes oxidantes ácidos fortes (Bacon et al., 2005). O uso destes reagentes objetiva estabelecer associações dos elementos traços com fases específicas (Teódulo et al., 2003).

O processo de extração sequencial é a determinação da concentração das diferentes formas químicas de um mesmo elemento em uma matriz. Assim sendo, os metais contidos no sedimento serão fracionados em formas geoquímicas específicas, sendo seletivamente extraídos pelo uso de reagentes apropriados que devem responder especificamente na forma geoquímica para o qual foi escolhido (Tessier et al.,1979).

O método identifica o metal entre quatro frações operacionalmente definidas, nomeadas como: Fração ácido solúvel ligada a carbonatos; Fração redutível a óxidos de ferro e manganês; Fração oxidável ligada a matéria orgânica e sulfetos; Fração residual fortemente associada as estruturas cristalinas dos minerais (Ashraf et al., 2012).

Para prever a capacidade de mobilização dos metais pesados em sedimentos, a determinação de sua concentração total não é suficiente. O comportamento dos metais no ambiente depende fundamentalmente da sua forma química, a qual influencia na mobilidade, na biodisponibilidade e na toxicidade dos organismos (Porto, et al., 2014).

Conforme Lemes (2001), para a análise de mobilização de metais em sedimentos aquáticos alguns fatores devem ser considerados: elevada concentração salina; potencial redox; queda no $\mathrm{pH}$; agentes naturais e sintéticos que podem formar complexos com os metais e ainda processos bioquímicos que afetam a mobilização desses metais.

Para inferir sobre o potencial de avaliação dos metais pesados nas várias 
frações dos sedimentos, a metodologia de extração sequencial tem sido uma importante ferramenta. Com muitas adaptações a partir da metodologia apresentada em 1979, por Tessier e colaboradores, o uso de extrações sequenciais, embora mais demorada, fornece informações detalhadas sobre a origem, o modo de ocorrência, disponibilidade, mobilização e transporte de metais pesados e a sua precisão e exatidão do procedimento da extração sequencial (Lopes, 2010).

De forma geral, o método busca fazer uma simulação das diferentes condições ambientais (ácido, alcalino, oxidante ou redutor) a qual o sedimento está exposto, podendo desta forma estudar o comportamento químico (mobilidade, solubilidade, biodisponibilidade e toxicidade) dos elementos traço no ambiente (Teódulo, 2003). 


\section{4 ÁREA DE ESTUdO}

\subsection{Represa Guarapiranga}

O reservatório de Guarapiranga está localizado na porção sudoeste RMSP (Figura 1 e Figura 2), é uma sub-bacia pertencente à Bacia Hidrográfica do Alto Tietê (BHAT), localizada na porção sudoeste de seus limites, e compreende à sete municípios (Tabela 2), são eles: São Paulo, Embu das Artes, Itapecerica da Serra, Embu Guaçu, Juquitiba, São Lourenço da Serra e Cotia. O reservatório sofre influência direta das bacias Embu Mirim, Santa Rita, Embu Guaçu e Caulim, além de rios, córregos e pequenos cursos d'água (Whately \& Cunha, 2006; Fontana, 2013; CETESB, 2014; Queiroz et al., 2015).

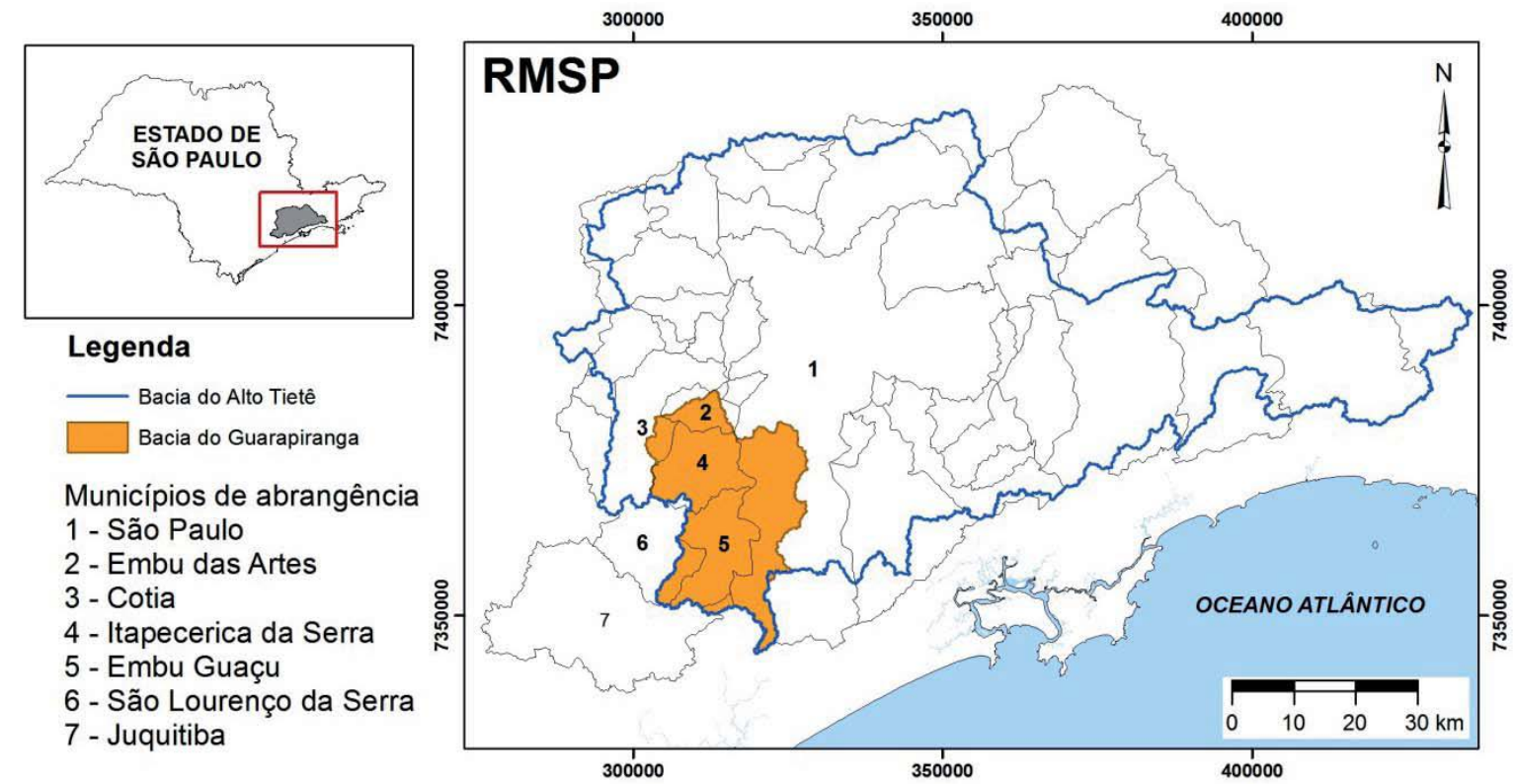

Figura 1. Localização da Bacia do Guarapiranga na Bacia do Alto Tietê e municípios de abrangência.

Fonte: Queiroz et al., 2015. 
(a)

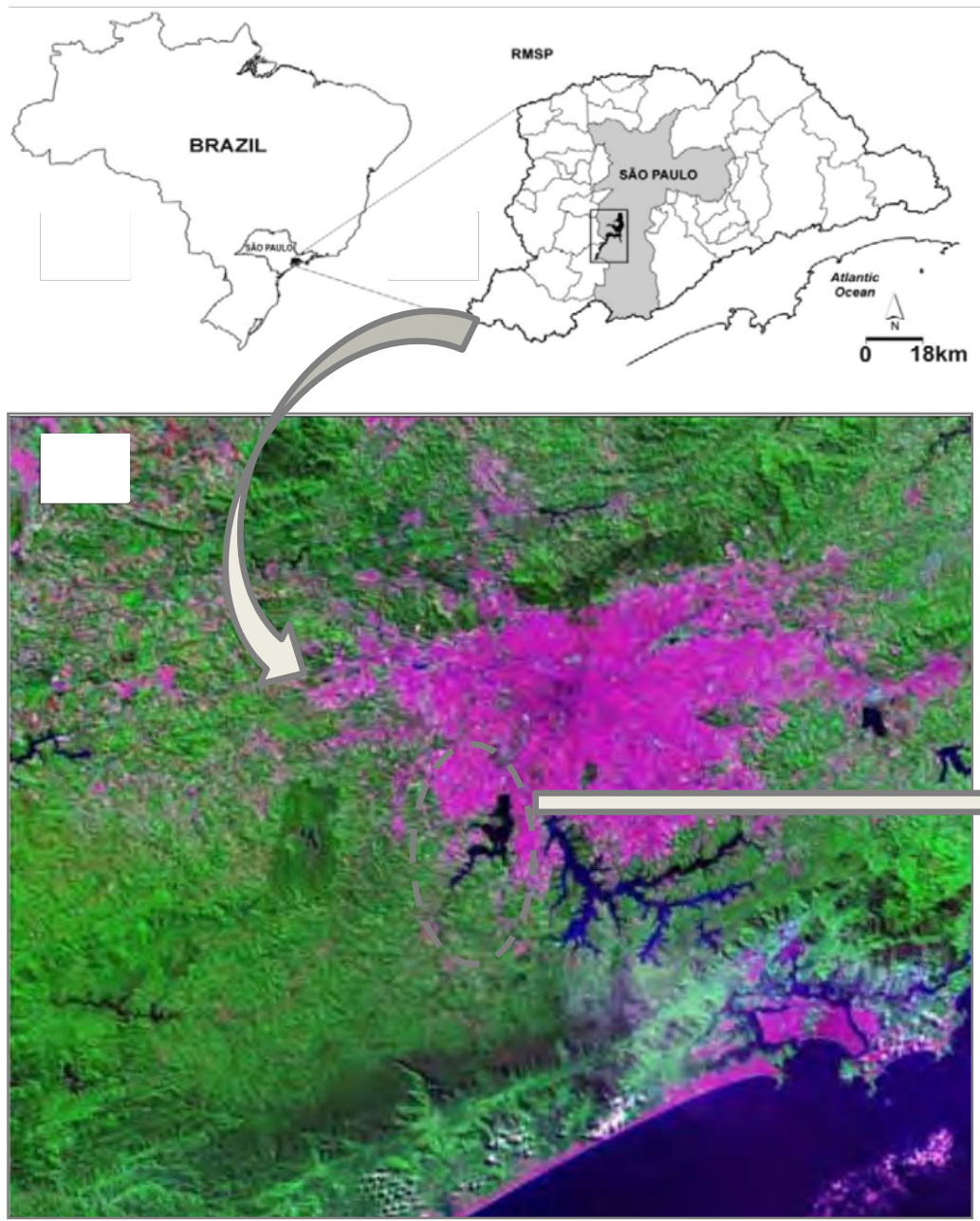

(b)

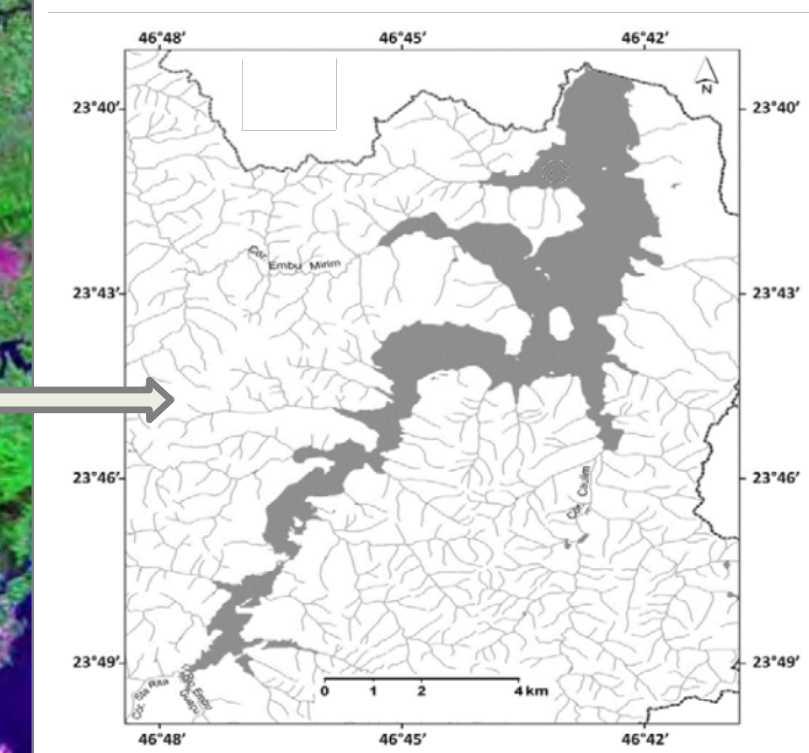

(c)

Figura 2. (a) Localização do Estado de São Paulo no Brasil, (b) localização da represa Guarapiranga na Região Metropolitana de São Paulo (RMSP) e (c) represa Guarapiranga.

Fonte: Fontana, 2013 
Tabela 2. Municípios inseridos na Bacia da Guarapiranga.

\begin{tabular}{lc}
\hline Municípios & $\begin{array}{c}\text { Área na Bacia } \\
\mathbf{( k m}^{\mathbf{2}}\end{array}$ \\
\hline Cotia & 22 \\
\hline Embu das Artes & 41 \\
\hline Embu Guaçu & 162 \\
\hline Itapecerica da Serra & 183 \\
\hline Juquitiba & 759 \\
\hline São Lourenço da Serra & 33 \\
\hline São Paulo & 211
\end{tabular}

Fonte: Whately \& Cunha, 2006 (modificado); Queiroz et al., 2015.

Com o objetivo de regularizar a vazão do Rio Tietê e consequentemente aumentar a geração de energia elétrica na Usina Hidrelétrica de Parnaíba, o reservatório Guarapiranga foi construído entre 1906-1909 pela empresa Canadense "The São Paulo Tramway, Light" e "Power Company" hoje a Eletropaulo, com o represamento do rio Guarapiranga. Sua área é de $36,18 \mathrm{~km}^{2}$, um volume total de água de $253 \times 10^{6} \mathrm{~m}^{3}$ e uma profundidade média de 5,7 m e $13 \mathrm{~m}$ (Whately \& Cunha, 2006, Queiroz et al, 2015).

A Guarapiranga é um dos principais mananciais da RMSP, em 1927 passou a contribuir com $1 \mathrm{~m} 3 / \mathrm{s}$ no abastecimento de água, atualmente é o segundo maior produtor de água de abastecimento, com vazões superiores a $12 \mathrm{~m} 3 / \mathrm{s}$, é responsável pelo abastecimento de água para aproximadamente 3,7 milhões de pessoas, ou seja, 20\% da população da RMSP (Richter et al., 2007). É superado apenas pelo sistema Cantareira (CETESB, 2014).

Os principais tributários que desaguam na represa são: na margem direita: Rio Bonito, Rio das Pedras, Parelheiros, Córregos Tanquinho e São José e na margem esquerda: Embu-mirim, Embu-Guaçu e Córregos Guaravirutuba, Itupú e Mombaça (Figura 3) (Fontana, 2013). 


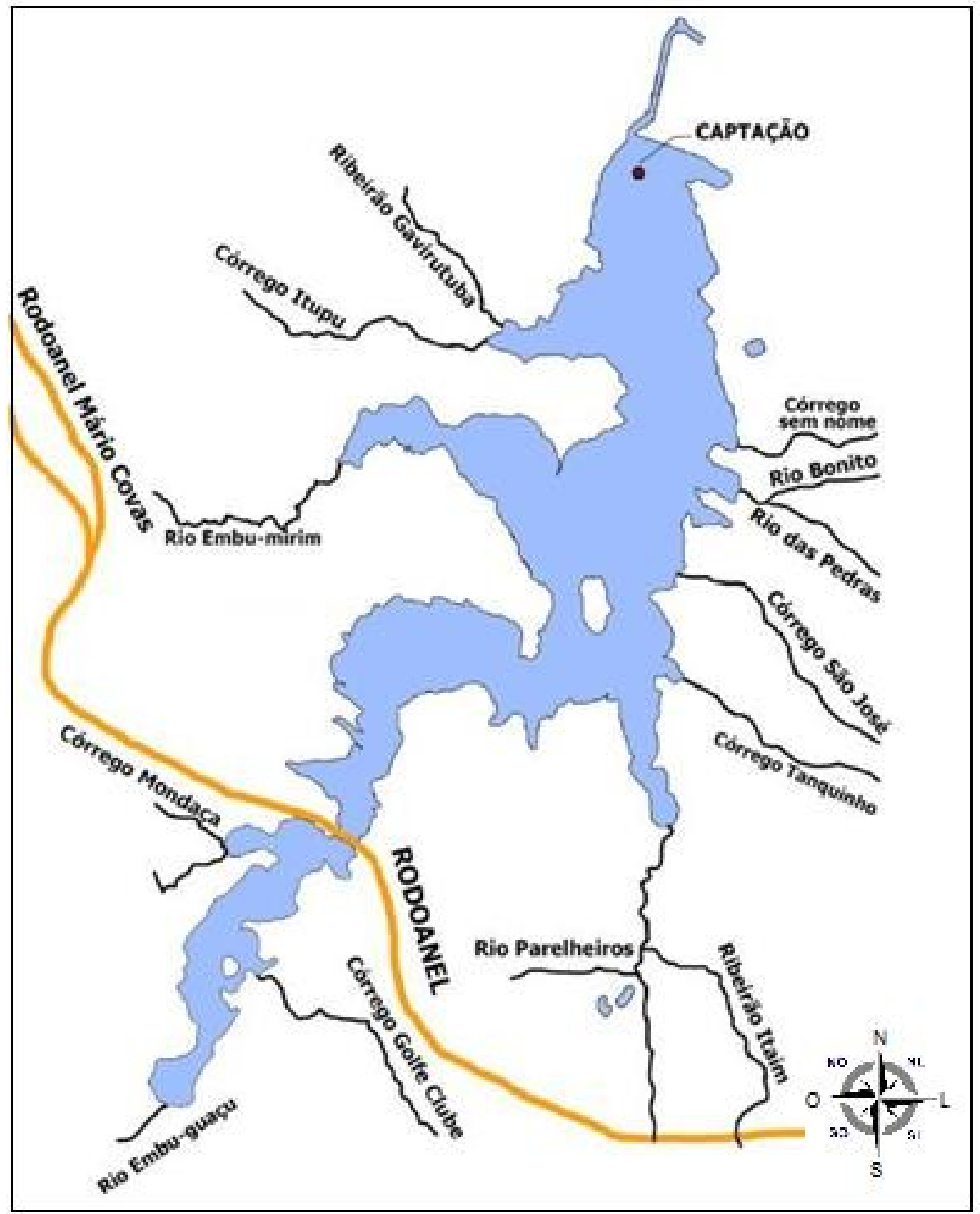

Figura 3. Represa Guarapiranga e seus tributários.

Fonte: Shihomatsu, 2015.

Além dos tributários, o sistema produtor Guarapiranga conta com duas transposições de água de outras bacias hidrográficas. A primeira e mais antiga é a reversão do Rio Capivari para o Rio Embu Guaçu. A segunda, em funcionamento desde 2000, porém de forma não contínua, consiste na reversão das águas do braço Taquacetuba da represa Billings (Figura 4), para o Rio Parelheiros (Whately \& Cunha, 2006). 


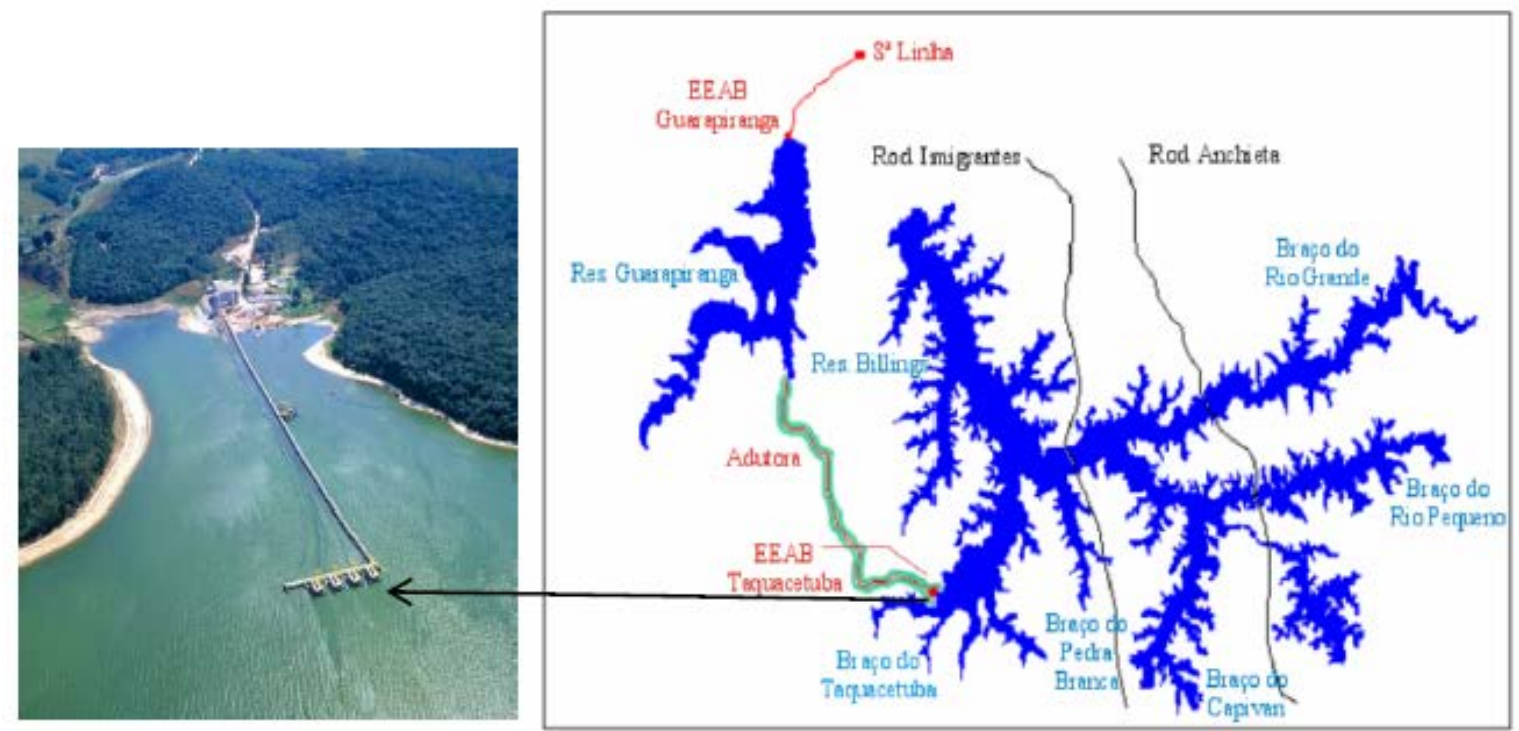

Figura 5 Estação de bombeamento do braço Taquacetuba da Billings para o reservatório Guarapiranga.

Fonte: (SABESP; Shiromoto et al., 2005)

Nos últimos anos, o reservatório vem enfrentando crescentes desafios, sendo atualmente o consumo igual ou ligeiramente superior à capacidade de produção da região. A este quadro deve ser adicionado o fato do agravamento gradual dos problemas de poluição, influenciadas pelas atividades antrópicas da região, relativa à urbanização descontrolada, lançamento de esgotos tratados e in natura, uso e ocupação do solo desordenado e pela industrialização da área, que oneram e dificultam o tratamento desta água. Este panorama preocupante é bastante discutido, levando à reflexão e busca de soluções para o problema (Mozeto et al., 2001; Richter et al., 2007; Tundisi, 2008).

\subsection{Uso e ocupação do solo no entorno da Represa}

A Bacia hidrográfica da Guarapiranga tem parte de seu território inserido na Área de Proteção Ambiental (APA) Municipal do Capivari Monos (8\%) e a totalidade na área de abrangência da Reserva da Biosfera do Cinturão Verde da Cidade de São Paulo, parte integrante da Reserva da Biosfera da Mata Atlântica. Em 2003, as áreas com vegetação remanescente de Mata Atlântica da região ocupavam apenas 37\% da área da bacia. A situação se agrava mais nas Áreas de Preservação Permanente 
(APP), onde uma parcela significativa $(37,6 \%)$ encontra-se ocupada por usos antrópicos (Whately \& Cunha, 2006)

O início da ocupação do entorno da represa Guarapiranga se deu na década de 20, com algumas chácaras, poucas residências, marinas, clubes e instalações religiosas (Shihomatsu, 2015).

Até a década de 40, devido ao potencial paisagístico, predominava o lazer como uso da represa. A partir da década de 60 , com a implantação da marginal do Rio Pinheiros, houve um crescimento de moradias de alto padrão na região, e, nas décadas de 70 e 80 com o deslocamento do setor terciário avançado às proximidades da Marginal do Rio Pinheiros acentuou-se esta tendência (Salles, 2000; Silva, 2005).

No mesmo período, na margem esquerda da represa, situado próximo ao Ribeirão Guavirutuba, houve uma proliferação de edificações populares em geral irregulares e clandestinas. Com o intuito de limitar a urbanização em áreas de manancial leis foram decretadas, como as Leis Estaduais 898/75 e 1.172/76. Entretanto, o resultado foi a desvalorização imobiliária, e, que mesmo com a promulgação das leis, verificou-se foi um intenso crescimento demográfico com surgimento de loteamentos com construções irregulares em uma área carente de qualquer infraestrutura (Tabela 3) (Silva, 2005).

Andrade e colaboradores (2015) realizou recentemente um mapeamento do uso do solo para avaliação da qualidade das águas do reservatório Guarapiranga, e avaliou também a dinâmica da cobertura da terra na bacia nos anos de 1986, 1996, 2010, e observou um avanço no crescimento da população e uso do solo para a região sul. O mesmo foi observado nos estudos referentes a qualidade do reservatório, desenvolvidos por Otomo (2015), Shihomatsu (2015) e Silva (2016). 
Tabela 3. Evolução da população - Guarapiranga e Billings - 1980/2006

\begin{tabular}{cccc}
\hline & \multicolumn{3}{c}{ População Residente } \\
\cline { 2 - 4 } Ano/Bacia & Guarapiranga & Billings & $\begin{array}{c}\text { Billings (sub-bacia) } \\
\text { Rio Grande }\end{array}$ \\
1980 & 325.000 & - & - \\
1991 & 548.000 & 534.400 & 124.200 \\
2000 & 754.000 & 841.000 & 177.000 \\
2006 & 925.000 & 976.000 & 202.000 \\
\hline
\end{tabular}

Fonte: São Paulo, 2009

Atualmente, a região se encontra densamente populosa, a ocupação espacial nas suas margens tem gerado grande impacto ambiental na qualidade da água em função, principalmente, do lançamento de esgoto não tratado na represa proveniente de bairros e loteamentos clandestinos e da ocupação desordenada de seu entorno. O esgoto e a poluição difusa constituem as principais fontes de poluição da represa, com sérias consequências para o abastecimento público de boa parte da RMSP (Whately \& Cunha, 2006; Andrade et al, 2015).

A evolução do uso e ocupação da área da bacia é expressiva, em meados da década de 1980, a cobertura vegetal correspondia a mais de $50 \%$ da área da bacia e a área construída representava 5,5\% (Fontana, 2013). A Figura 5 revela este panorama, destacando a área construída e urbanizada que se encontram concentradas no município de São Paulo próximo à barragem, às margens da represa (domínio 1). Outro eixo de áreas construídas se encontra ao longo da Rodovia Regis Bittencourt que envolvem os municípios de Embu e Itapecerica da Serra (domínio 2). Mais a montante, no extremo sul da margem da represa algumas áreas construídas (domínio 3). As áreas de mata concentram na região sul (domínios 3 e 4) (Fontana, 2013). 


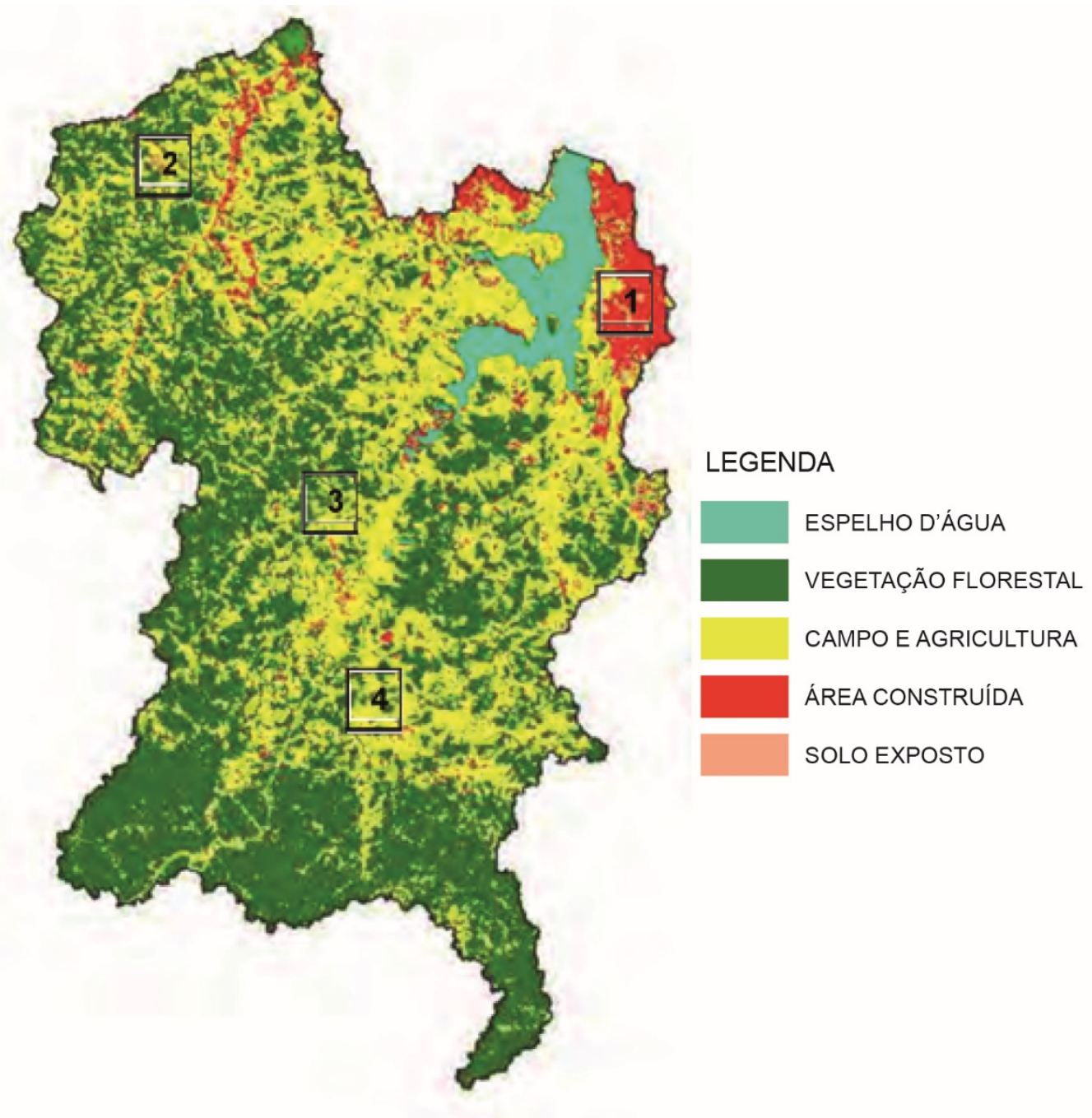

Figura 5. Mapa de uso e cobertura da terra da Bacia do Guarapiranga no ano de 1986. Os domínios (números de 1 a 4, com observações no texto) assinalam áreas de maior concentração urbana na bacia.

Fonte: Fontana, 2013.

No decorrer dos anos, houve um expressivo aumento da área construída na bacia, com um avanço às margens da represa, principalmente na porção norte. Com esta ocupação desordenada e por vezes irregular, observou-se redução da cobertura vegetal que passou a representar 38\% no início dos anos 2000. Este cenário comparado ao ano de 1986 demonstra que as áreas urbanizadas aumentaram duas vezes e as áreas relacionadas a campo e agricultura sofreram redução de um terço. No caso das áreas de cobertura vegetal, houve uma redução de aproximadamente um quinto, podendo ser considerada estável (Fontana, 2013). 
Em 2006 foi aprovada a Lei Específica da Área de Proteção e Recuperação da Guarapiranga, lei $n^{0}$ 12.233/2006 (APRM-G), ficou definido que a área na Bacia Hidrográfica do Guarapiranga deveria ser protegida e recuperada.

Nos últimos anos, a área de entorno do Guarapiranga se mostrou mais estável com relação ao crescimento horizontal, entretanto, nota-se uma ocupação mais densa em determinadas áreas, principalmente próximo a barragem (Arruda et al., 2016). Este cenário é apresentado na Figura 6. Na Figura 6B referente à região do Guarapiranga no ano de 2014 verifica-se que há uma pequena expansão de urbanização em relação ao ano de 2002 apresentado na Figura 6A.

A heterogeneidade dos tipos de categorias de cobertura do solo na bacia da represa Guarapiranga revelados na Figura 7 permite identificar as principais fontes de poluição da área de contribuição do reservatório (Bicudo e Bicudo, 2017). 
(A)Ano 2002

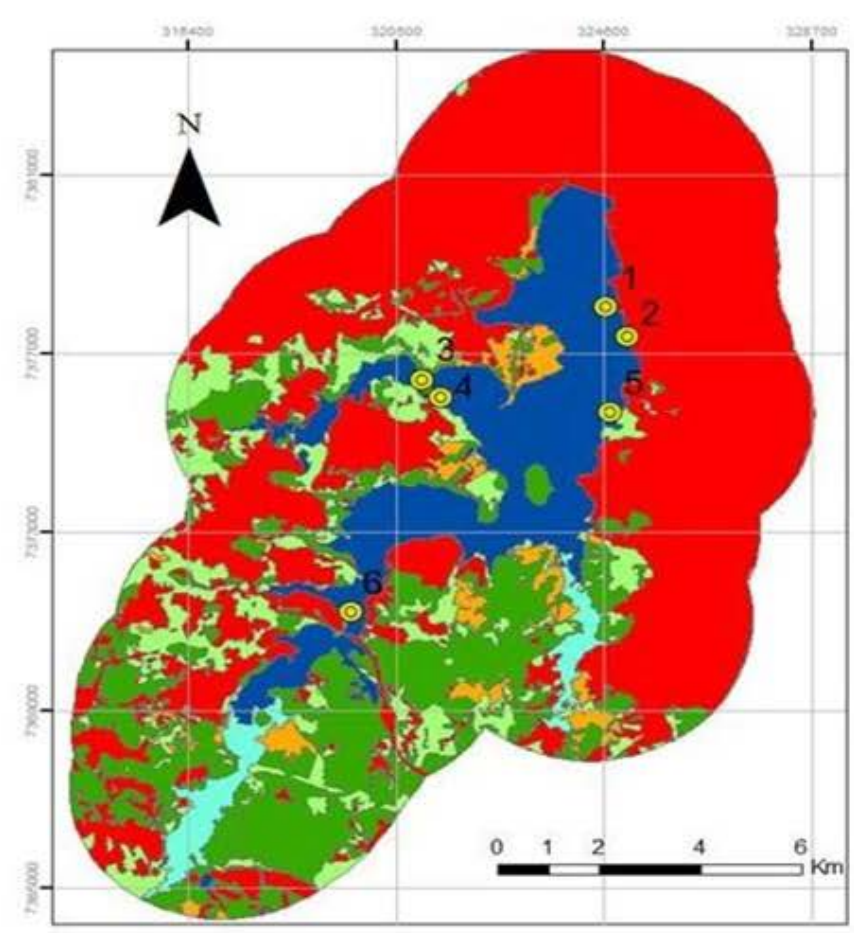

(B) Ano 2014

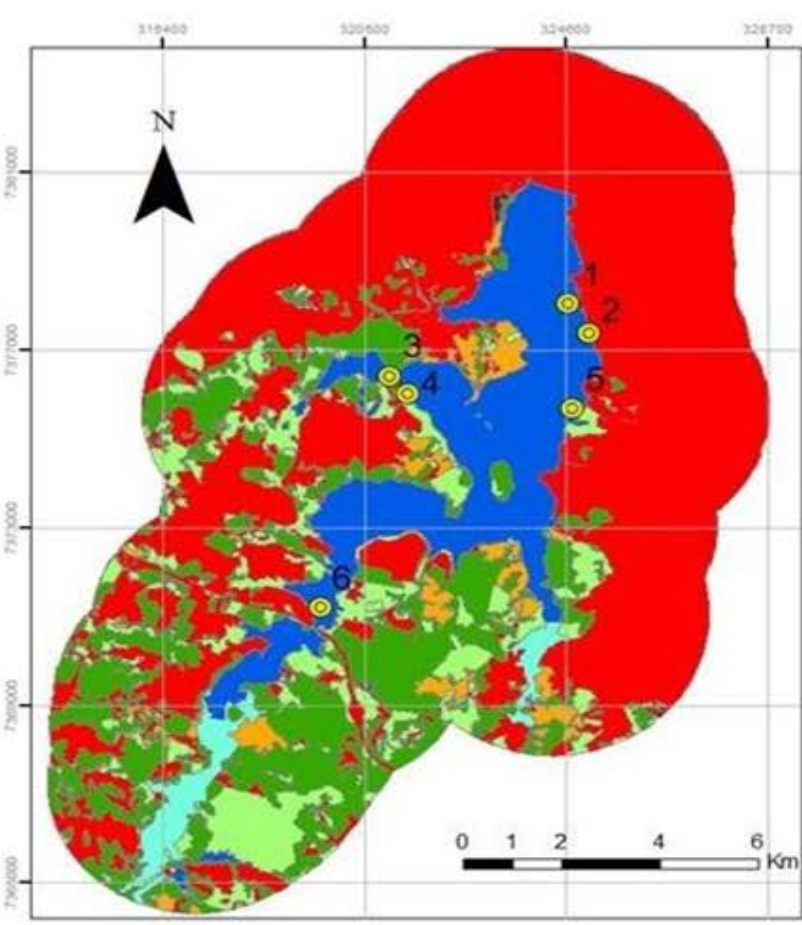

Uso do Solo/Borda Guarapiranga $3 \mathrm{~km}$ CLASSES

aREA URBANA

CHACARAE CONDOMinios

$\square$ CAMPO

MATA

VARZEA

represaelagos

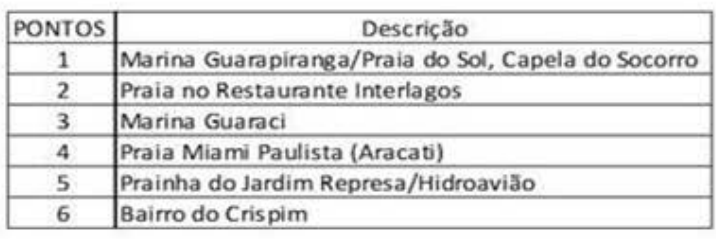

Figura 6: Uso e ocupação do solo na região onde se localiza a represa Guarapiranga, comparativo entre os anos de 2002 (A) e 2014 (B).

Fonte: Arruda et al., 2016. 


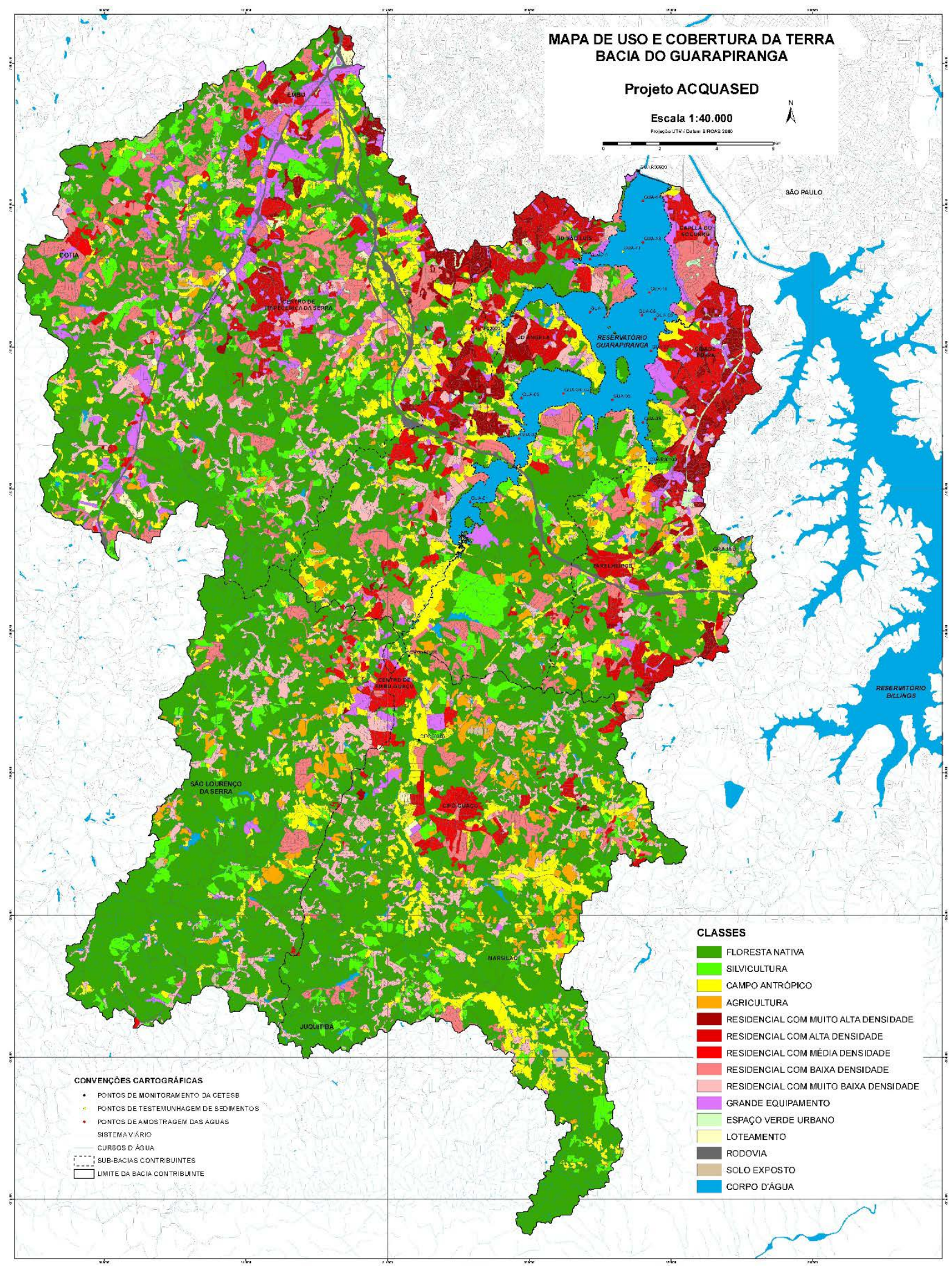

Figura 7: Mapa de cobertura e uso da terra na Bacia da represa Guarapiranga.

Fonte: Andrade, M. R. M. Disponível em: < http://www.cemaden.gov.br/livro-sobre-arepresa-do-guarapiranga-tem-participacao-de-pesquisador-do-cemaden/>. 
Atualmente, a paisagem apresenta uma diversidade de tipos e usos na ocupação do solo (Figura 8, Figura 9 e Figura 10), caracterizando-se como uma região que apresentou crescimento rápido e desordenado, por vezes loteamentos clandestinos e industrias irregulares, resultando em um conjunto de problemas socioambientais que Ihe são inerentes (Whately e Cunha, 2006; Andrade et al, 2015; Arruda et al., 2016; Hisayasu et al., 2016).

Outros usos, tais como recreação, lazer, industrial, rural e comercial podem ser observados. De acordo com Whately e Cunha (2006), os usos antrópicos incluem atividades agrícolas, mineração, reflorestamento, indústrias e áreas de lazer. Já os usos residenciais, de acordo com os mesmos autores, compreendem áreas com ocupação urbana de média a alta densidade, ocupação dispersa e condomínios.

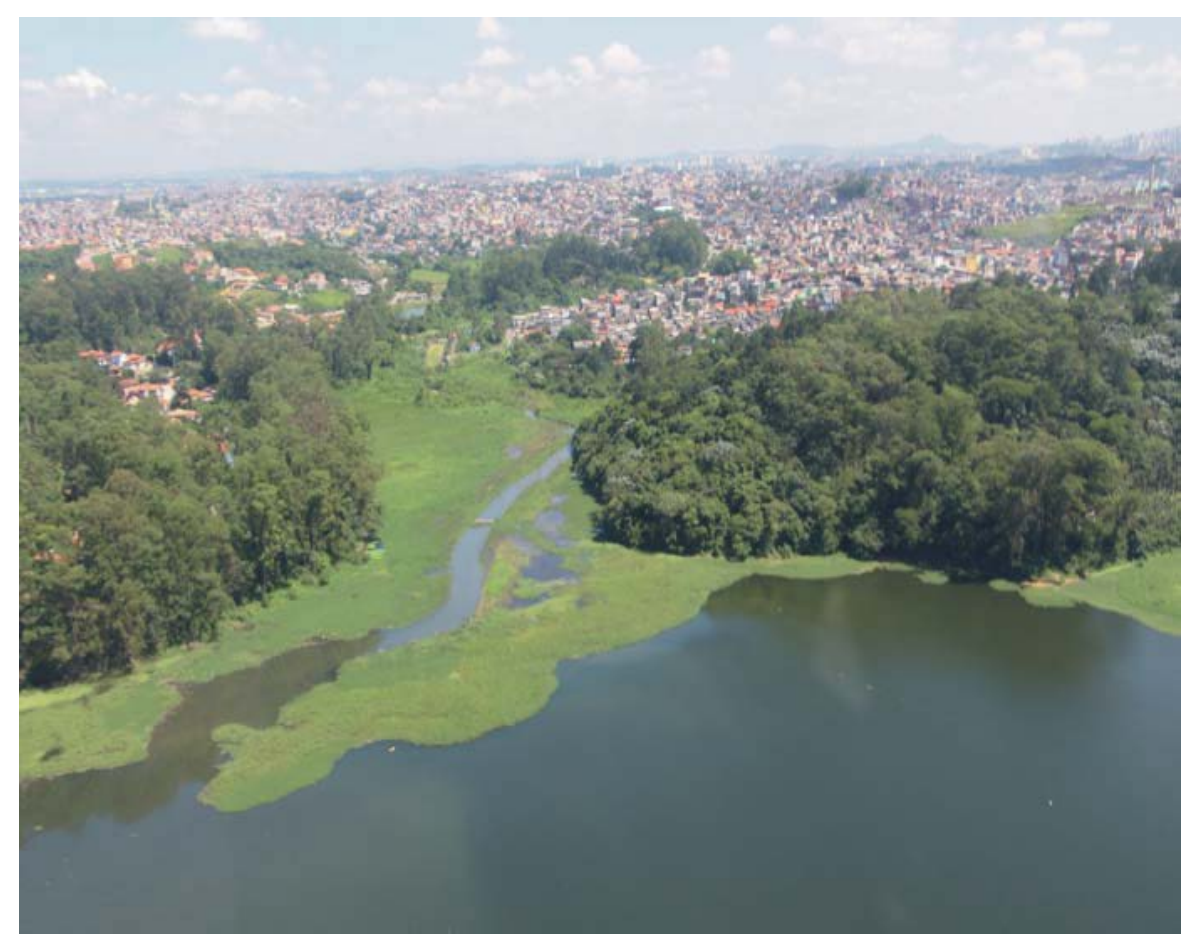

Figura 8. Reservatório Guarapiranga Desembocadura do córrego Guavirutuba com expressivo aglomerado urbano e área de eutrofização.

Fonte: Queiroz et al., 2015. 


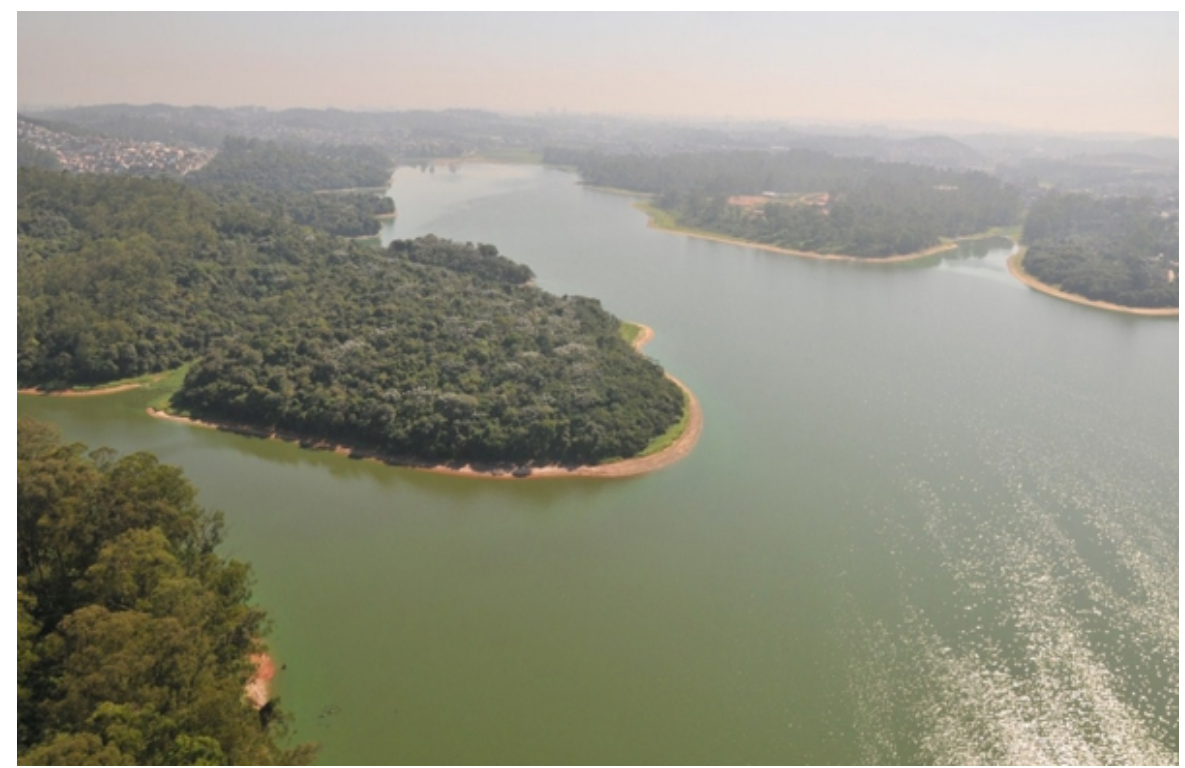

Figura 9. Reservatório Guarapiranga, região a montante com áreas preservadas. Fonte:http://correio.rac.com.br/_conteudo/2014/05/capa/nacional/172756-socorrocom-agua-do-guarapiranga-sera-dobrado.html.

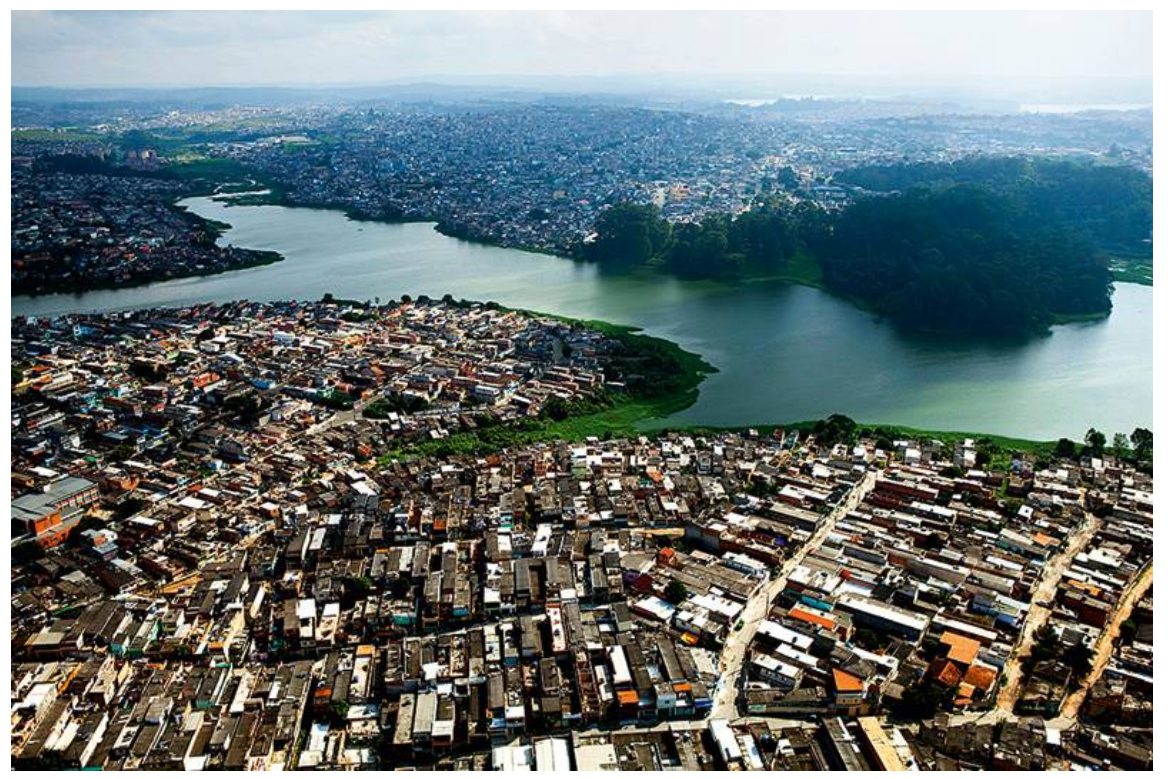

Figura 10. Reservatório Guarapiranga, região próxima à barragem com intensa ocupação por residências e assentamentos clandestinos.

Fonte:https://vejasp.abril.com.br/cidades/represa-guarapiranga-problemasambientais/ 


\section{MATERIAIS E MÉTODOS}

\subsection{Materiais e Equipamentos}

Para o desenvolvimento deste trabalho foram utilizados os seguintes equipamentos:

- $\quad$ Frascos de polipropileno para centrífuga de capacidade $50 \mathrm{~mL}$ (tubos Falcon);

- Mesa agitadora;

- $\quad$ Centrífuga;

- Bloco Digestor;

- $\quad$ Pipeta automática;

- Balões volumétricos;

- $\quad$ Provetas;

- Balança analítica;

- $\quad$ Forno Micro-ondas;

- $\quad$ Espectrômetro de Emissão Óptica com Plasma de Argônio (ICP-OES), ARCOS da Spectro®, com tocha axial, nebulizador Meinhard ${ }^{\circledR}$, acoplado a câmera de nebulização ciclônica e sistema de detecção baseada em dispositivos de carga acoplada (CCD) (Figura 11).

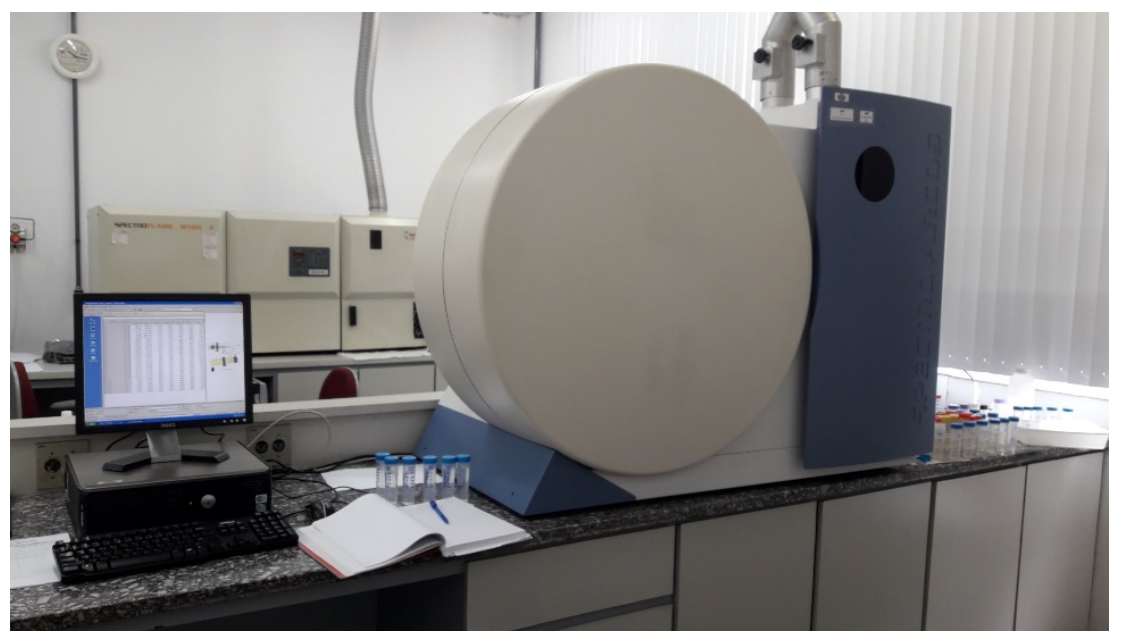

Figura 11. Espectrômetro de Emissão Óptica com Plasma de Argônio (ICP-OES) (SPECTRO ARCOS) 
Todas as vidrarias e frascos utilizados nos procedimentos foram imersos em solução de HNO3 $1 \mathrm{~mol} \mathrm{~L}^{-1}$ por $24 \mathrm{~h}$ e adequadamente enxaguados em água deionizada.

\subsection{Reagentes e Soluções}

Todos os reagentes utilizados foram de grau de pureza analítica, e as soluções foram preparadas utilizando água ultrapura, obtida a partir do sistema de purificação de água por Osmose Reversa, ELIX 3, Millipore ${ }^{\circledR}$.

As curvas de calibração para todos os elementos foram preparadas a partir de soluções padrão para ICP, das marcas J.T. Baker e Merck, de 1.000 mg L-1, rastreáveis ao NIST. Para o preparo das diluições foi utilizada água ultrapura ELIX 3, Millipore ${ }^{\circ}$.

\subsection{Coleta e Preparo das Amostras}

Os estudos geoquímicos realizados no presente estudo foram desenvolvidos em harmonia e complementação ao projeto temático FAPESP. A campanha de coleta das amostras de sedimento superficial no reservatório ocorreu em agosto de 2011 , na estação do inverno, período de menor incidência de chuva. As coletas foram realizadas com auxílio de barcos e apoio da equipe da SABESP, Companhia de Saneamento Ambiental de São Paulo.

Quatorze sítios amostrais foram selecionados a partir do projeto Aquased, com base nas características do reservatório. Foram estudados os elementos majoritários $\mathrm{Al}, \mathrm{Fe}, \mathrm{Mn}$ e os elementos traço $\mathrm{Cr}, \mathrm{Cu}, \mathrm{Zn}$ e P.

A seleção dos sítios amostrais foi determinada com o intuito de avaliar o reservatório de uma forma ampla, além de verificar a influência dos aportes dos tributários considerados mais importantes (Embu-Mirim e Embu-Guaçu) e conhecer a influência das sub-bacias que compõem o seu sistema. Para tanto houve a colaboração dos representantes do Centro de Integração e Gerenciamento de Informações da Coordenadoria de Planejamento Ambiental da Secretaria do Meio 
Ambiente (SMA), Instituto de Pesquisas Energéticas e Nucleares (IPEN) e do Instituto de Botânica.

Desta forma, 14 (quatorze) pontos ou sítios amostrais foram selecionados para a amostragem, sendo que 3 (três) destes identificados como sendo pontos de monitoramento da SABESP e quatro sítios estão próximos aos pontos monitorados pela CETESB - Relatório anual de qualidade de águas interiores (CETESB, 2016).

O mapa georreferenciado dos pontos de coleta está apresentado na Figura 12. As coordenadas geográficas com a descrição dos pontos, entre outras observações de coleta, são apresentadas na Tabela 4. 


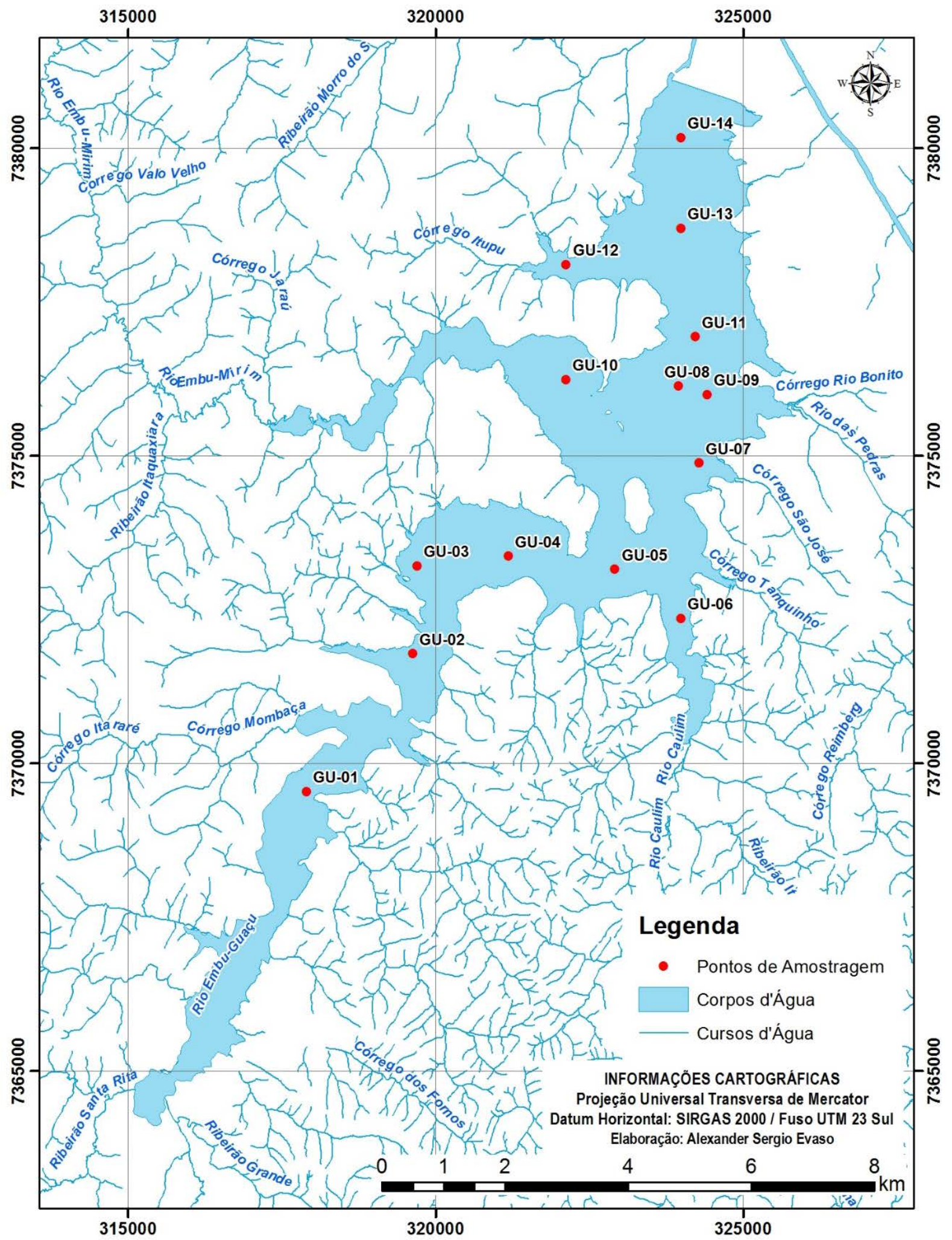

Figura 12. Mapa dos pontos de coleta do reservatório do Guarapiranga. 
Tabela 4. Descrição dos pontos de coleta de amostras de sedimento e respectivas coordenadas geográficas do reservatório da Guarapiranga

\begin{tabular}{|c|c|c|c|}
\hline $\begin{array}{l}\text { Pontos de } \\
\text { Referência }\end{array}$ & $\begin{array}{c}\text { Local de } \\
\text { amostragem } \\
\text { (no mapa) }\end{array}$ & Coordenadas & $\begin{array}{l}\text { Observações } \\
\text { (Agosto de 2011) }\end{array}$ \\
\hline GU000-01 & GU-01 & $\begin{array}{l}23^{\circ} 46,496^{\prime} \mathrm{S} \\
46^{\circ} 47.220^{\prime} \mathrm{W}\end{array}$ & $\begin{array}{l}\text { Influência do rio Embu-Guaçu. } \\
\text { Local mais protegido com duas espécies de } \\
\text { macrófitas. }\end{array}$ \\
\hline GU000-02 & GU-02 & $\begin{array}{l}23^{\circ} 45,295^{\prime} \mathrm{S} \\
46^{\circ} 46.187^{\prime} \mathrm{W}\end{array}$ & $\begin{array}{c}\text { Influência do Córrego Mombaça (esgoto) } \\
\text { Urbanização desordenada. Com bolhas de gás na } \\
\text { superfície. Rodoanel }\end{array}$ \\
\hline GU000-03 & GU-03 & $\begin{array}{l}23^{\circ} 44.522^{\prime} \mathrm{S} \\
46^{\circ} 46.136^{\prime} \mathrm{W}\end{array}$ & Com cheiro de esgoto e banco de Salvinia. \\
\hline GU106-04 & GU-04 & $\begin{array}{l}23^{\circ} 44,446^{\prime} \mathrm{S} \\
46^{\circ} 45.258^{\prime} \mathrm{W}\end{array}$ & $\begin{array}{c}\text { Próximo à estação de monitoramento em tempo real } \\
\text { da Sabesp. }\end{array}$ \\
\hline GU000-05 & GU-05 & $\begin{array}{l}23^{\circ} 44,575^{\prime} \mathrm{S} \\
46^{\circ} 44.242^{\prime} \mathrm{W}\end{array}$ & Entre a Ilha da Formiga e o Solo Sagrado. \\
\hline GU107-06 & GU-06 & $\begin{array}{l}23^{\circ} 45.012^{\prime} \mathrm{S} ; \\
46^{\circ} 43.615^{\prime} \mathrm{W}\end{array}$ & $\begin{array}{l}\text { Várzea da Transposição do Taquacetuba (encerrada } \\
\text { em 2009). }\end{array}$ \\
\hline GU108-07 & GU-07 & $\begin{array}{l}23^{\circ} 43.647^{\prime} \mathrm{S} \\
46^{\circ} 43.423^{\prime} \mathrm{W}\end{array}$ & $\begin{array}{c}\text { Entre a saída do Córrego Tanquinho e o Córrego } \\
\text { São José. }\end{array}$ \\
\hline GU000-08 & GU-08 & $\begin{array}{l}23^{\circ} 42,969^{\prime} \mathrm{S} \\
46^{\circ} 43,612^{\prime} \mathrm{W}\end{array}$ & Floração de cianobactérias (Dia ensolarado). \\
\hline GU109-09 & GU-09 & $\begin{array}{l}23^{\circ} 43,046^{\prime} \mathrm{S} \\
46^{\circ} 43,340^{\prime} \mathrm{W}\end{array}$ & $\begin{array}{l}\text { Próximo à saída do Rio das Pedras e Rio Bonito. } \\
\text { Apresentava uma floração. }\end{array}$ \\
\hline GU105-10 & GU-10 & $\begin{array}{l}43^{\circ} 42,899^{\prime} \mathrm{S} \\
46^{\circ} 44,687^{\prime} \mathrm{W}\end{array}$ & $\begin{array}{l}\text { Ponto que sofre influência do Rio Embu-Mirim. } \\
\text { Cianobactérias. Entre a antena e o Heliporto. }\end{array}$ \\
\hline GU108-11 & GU-11 & $\begin{array}{l}23^{\circ} 42,534^{\prime} \mathrm{S} \\
46^{\circ} 43,449^{\prime} \mathrm{W}\end{array}$ & Ponto próximo ao Córrego sem nome. \\
\hline GU103-12 & GU-12 & $\begin{array}{l}23^{\circ} 41,885^{\prime} \mathrm{S} \\
46^{\circ} 44,673^{\prime} \mathrm{W}\end{array}$ & $\begin{array}{l}\text { Próximo às saídas do Córrego Itupu e do Ribeirão } \\
\text { Guavirutuba. Cheiro forte de esgoto próximo à } \\
\text { estação de remoção de nutrientes. }\end{array}$ \\
\hline GU102-13 & GU-13 & $\begin{array}{l}23^{\circ} 41,580^{\prime} \mathrm{S} \\
46^{\circ} 43,573^{\prime} \mathrm{W}\end{array}$ & $\begin{array}{l}\text { Cheiro forte. } \\
\text { Ponto com aplicação de Algicida. }\end{array}$ \\
\hline GU000-14 & GU-14 & $\begin{array}{l}23^{\circ} 40,782^{\prime} \mathrm{S} \\
46^{\circ} 43,559^{\prime} \mathrm{W}\end{array}$ & $\begin{array}{c}\text { Em frente à captação de água. } \\
\text { Entre o late Clube e o começo do Parque } \\
\text { Guarapiranga. Pode ter sofrido influência da } \\
\text { aplicação de algicida. Algas com aparência } \\
\text { esbranquiçada. }\end{array}$ \\
\hline
\end{tabular}


No período de agosto de 2011, cerca de $800 \mathrm{~g}$ de amostras de sedimentos superficiais compostas foram coletadas em cada sítio pré-determinado, de acordo com as recomendações do USGS37 e do guia de coletas da CETESB \& ANA (2011). Foi utilizado um amostrador (testemunhador) de polietileno para sedimento, tubular por gravidade modificado, tipo Kajak (Figura 13), da marca UWITEC (MONDSEE, Áustria) pertencente ao Instituto Internacional de Ecologia. Foram utilizados os dois primeiros centímetros superficiais, que usualmente representam de um a dois anos de deposição. Após a coleta, as amostras foram armazenadas em frascos previamente etiquetados conforme o local de amostragem e transportados, sob refrigeração $\left( \pm 4^{\circ} \mathrm{C}\right)$, até o laboratório, onde foram transferidas para recipientes adequados e colocadas em uma estufa com temperatura controlada a $60 \pm 5^{\circ} \mathrm{C}$ por 5 dias. Após este procedimento, as amostras foram desagregadas em almofariz de ágata, quarteadas, fracionados por peneiramento, sendo a fração mais fina ( $<63 \mu \mathrm{m})$ tomada para estes experimentos (Otomo, 2015; Silva, 2016).

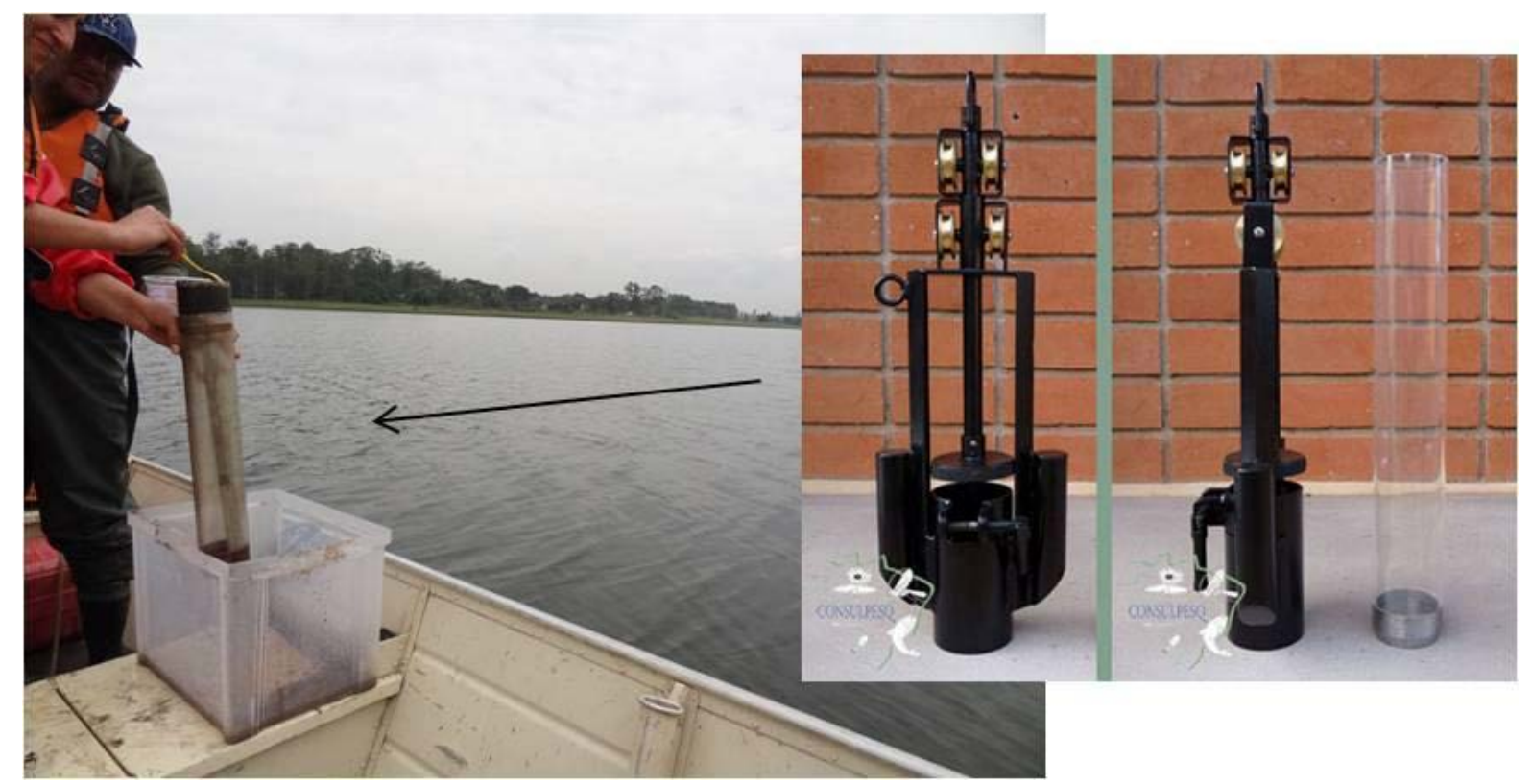

Figura 13. Amostragem de sedimento e amostrador de sedimento tubular de gravidade (tipo Kajak) em detalhe.

Fonte: Otomo, 2015. 


\subsection{Extração Sequencial}

O procedimento de extração sequencial foi adaptado e otimizado a partir do método desenvolvido por Ashraf et al. (2012). A seguir está descrito o protocolo analítico utilizado:

- Fração 1 - ácido solúvel ligada a carbonatos, Massas de 0,5 g 0 0,1 mg de amostras de sedimentos foram pesadas e transferidas para frascos de polipropileno para centrífuga de capacidade $50 \mathrm{~mL}$ (tubos Falcon). A essa massa foi adicionada uma solução de $20 \mathrm{~mL}$ de ácido acético 0,11 Mol L-1. Esta mistura foi levada a um agitador horizontal (shaker) por 16 horas sob rotação de 30 rpm. Após essa primeira extração realizada no shaker, os tubos Falcon contendo os extratos foram levados para uma centrífuga por 20 minutos a uma rotação de 3000 rpm. A solução sobrenadante foi retirada e reservada em outro tubo Falcon para posterior determinação dos analitos extraídos. O substrato foi lavado com $10 \mathrm{~mL}$ de água deionizada ultrapura (MilliQ), agitado novamente por 15 minutos no shaker a 30 rpm e posteriormente levados a centrifugação por 20 minutos a 3000 rpm. O segundo sobrenadante desta fração foi retirado e agregado ao extrato anterior.

- Fração 2 - redutível a óxidos de ferro e manganês, ao resíduo da fração 1 foi adicionado $20 \mathrm{~mL}$ de solução de hidrocloreto de hidroxilamina $0,5 \mathrm{Mol} \mathrm{L}^{-1} \mathrm{e}$ seguindo os passos da fração 1 foi agitado e centrifugado, o sobrenadante foi removido, o substrato foi lavado com $10 \mathrm{~mL}$ de água deionizada ultrapura (MilliQ), agitado e centrifugado e o segundo sobrenadante também removido para outro tubo para determinação posterior.

- Fração 3 - oxidável ligada a matéria orgânica, ao resíduo da fração 2 foi adicionado $5 \mathrm{~mL}$ de solução de peróxido de hidrogênio 8,8 $\mathrm{Mol} \mathrm{L}^{-1} \mathrm{com} \mathrm{pH}$ ajustado 2-3 em pequenas alíquotas. O tubo foi parcialmente coberto e deixado em temperatura ambiente por uma hora com agitação ocasional. A digestão ocorreu em banho maria por 1 hora a $85^{\circ} \mathrm{C}$ com agitação ocasional nos primeiros 30 minutos, sendo o volume reduzido a 2-3 mL. Outros $5 \mathrm{~mL}$ da solução de peróxido de hidrogênio $8,8 \mathrm{Mol} \mathrm{L}^{-1}$ foram adicionados, e novamente foram levados ao aquecimento a $85^{\circ} \mathrm{C}$ até quase evaporação total. Após resfriamento dos frascos a temperatura ambiente, foram adicionado $25 \mathrm{~mL}$ de 
solução de acetato de amônia $1 \mathrm{Mol} \mathrm{L}^{-1}$, com pH 2 ajustado com ácido nítrico concentrado. Esta mistura foi levada ao shaker por 16 horas sob agitação de 30 rpm. Após extração, este foi centrifugado a 3000 rpm por 20 minutos para separação das fases. O sobrenadante foi retirado e o resíduo lavado com 10 $\mathrm{mL}$ de água MilliQ, agitado no shaker por 15 minutos a 30 rpm e em seguida centrifugado por 20 minutos a 3000 rpm. O sobrenadante foi removido para outro tubo para determinação posterior.

- Fração 4 - residual, o resíduo da fração 3 foi transferido para uma célula de teflon de micro-ondas numa mistura (3:1) de ácido nítrico / ácido fluorídrico e executado o programa de aquecimento descrito na Tabela 5 por 3 ciclos. Após esfriar, para garantia do procedimento, as amostras digeridas foram filtradas em papel filtro qualitativo.

Tabela 5. Programa de aquecimento do forno micro-ondas para amostras de sedimento.

\begin{tabular}{c|c|c|c|c|c|c|c|c|c}
\hline T1 & Potencia & T2 & Potencia & T3 & Potencia & T4 & Potencia & T5 & Potencia \\
\hline 1 & $250 \mathrm{~W}$ & 3 & $400 \mathrm{~W}$ & 8 & $650 \mathrm{~W}$ & 8 & $790 \mathrm{~W}$ & 25 & $0 \mathrm{~W}$ \\
\hline
\end{tabular}

$\mathrm{T}=$ Tempo em minutos. 
De modo simplificado, a Tabela 6 apresenta um resumo do protocolo analítico aplicado.

Tabela 6. Protocolo analítico da extração sequencial modificado (Ashraf et al., 2012)

\begin{tabular}{|c|c|c|c|c|}
\hline Fração & $\begin{array}{c}\text { Fase extraível do } \\
\text { metal e elementos } \\
\text { traços no } \\
\text { sedimento }\end{array}$ & $\begin{array}{c}\text { Reagentes I } \\
\text { concentração } \\
\text { das soluções }\end{array}$ & $\begin{array}{c}\text { Temperatura } \\
\text { de extração } \\
\left({ }^{\circ} \mathrm{C}\right)\end{array}$ & $\begin{array}{c}\text { Condições } \\
\text { operacionais }\end{array}$ \\
\hline $\begin{array}{c}\text { F1 } \\
\text { (Trocável) } \\
\text { Biodisponível }\end{array}$ & $\begin{array}{l}\text { Ligado a cátions } \\
\text { trocáveis e } \\
\text { carbonatos }\end{array}$ & $\begin{array}{l}\text { Ácido acético } \\
0,11 \mathrm{Mol} \mathrm{L}^{-1}\end{array}$ & $22 \pm 5$ & $\begin{array}{c}\text { Agitação } \\
\text { mecânica em } \\
\text { agitador do tipo } \\
\text { "Shaker", por 16 h } \\
\text { ("overnight") }\end{array}$ \\
\hline $\begin{array}{c}\text { F2 } \\
\text { (Redutível) } \\
\text { Biodisponível } \\
\text { em ambiente } \\
\quad \text { redutor }\end{array}$ & $\begin{array}{l}\text { Ligado a óxidos e } \\
\text { hidróxidos de Fe e } \\
\text { Mn }\end{array}$ & $\begin{array}{c}\text { Cloridrato de } \\
\text { hidroxilamina } \\
0.5 \mathrm{Mol} \mathrm{L}^{-1} \\
(\mathrm{pH} \mathrm{1,5)}\end{array}$ & $22 \pm 5$ & $\begin{array}{c}\text { Agitação } \\
\text { mecânica em } \\
\text { agitador do tipo } \\
\text { "Shaker", por 16 h } \\
\text { ("overnight") }\end{array}$ \\
\hline $\begin{array}{c}\text { F3 } \\
\text { (Oxidável) } \\
\text { Relativamente } \\
\text { biodisponível }\end{array}$ & $\begin{array}{l}\text { Complexado pela } \\
\text { matéria orgânica e } \\
\text { sulfetos }\end{array}$ & $\begin{array}{c}\mathrm{H}_{2} \mathrm{O}_{2} \\
\text { 8.8 Mol L-1 } \\
(\mathrm{pH} 2-3) \\
\text { Acetato de } \\
\text { amônio 1,0 } \\
\mathrm{Mol} / \mathrm{L}^{-1} \\
(\mathrm{pH} \mathrm{2})\end{array}$ & $22 \pm 5$ & $\begin{array}{l}\text { Digestão por } 1 \mathrm{~h} \\
\text { com agitação } \\
\text { ocasional } \\
\text { Digestão por } 1 \mathrm{~h}\end{array}$ \\
\hline $\begin{array}{c}\text { F4 } \\
\text { (Residual) } \\
\text { Não } \\
\text { biodisponível }\end{array}$ & $\begin{array}{l}\text { Associado aos } \\
\text { minerais silicatos }\end{array}$ & $\mathrm{HNO}_{3} / \mathrm{HF}(3: 1)$ & & $\begin{array}{l}\text { Digestão em } \\
\text { micro ondas }\end{array}$ \\
\hline
\end{tabular}

\subsection{Método Analítico}

As concentrações dos metais e/ou elementos traços nos extratos sobrenadantes foram determinadas no Espectrômetro de Emissão Atômica com Fonte de Plasma Indutivamente Acoplado (modelo ARCOS, Spectro, ICP-OES), no Laboratório de Análises Química e Ambiental do Centro de Química e Meio Ambiente/ Instituto de Pesquisas Energéticas e Nucleares.

As soluções estoque foram preparadas a partir de soluções padrão em concentrações de $1000 \mu \mathrm{g} \mathrm{mL}$-1. Foram preparadas soluções multielementares em diferentes concentrações e uma solução representando o branco. 
O método da curva analítica por meio do uso de soluções padrões multielementares para os elementos $\mathrm{Fe}, \mathrm{Al}, \mathrm{Zn}, \mathrm{Cr}, \mathrm{Cu}, \mathrm{Mn}$ e $\mathrm{P}$ seguiu o processo descrito por Cotrim (2006) e as condições de operação do ICP-OES estão apresentadas na Tabela 7.

Tabela 7. Condições Operacionais do ICP-OES

\begin{tabular}{cc}
\hline Padrões Operacionais & Condições \\
\hline Potência do Plasma & $1200 \mathrm{~W}$ \\
Gás Refrigerante & $28 \mathrm{~L} \mathrm{~min}^{-1}$ \\
Gás Auxiliar & $1,5 \mathrm{~L} \mathrm{~min}^{-1}$ \\
Pressão do Nebulizador & $2,8 \mathrm{bar}^{-1}$ \\
Fluxo da amostra & $1,5 \mathrm{~mL} \mathrm{~min}^{-1}$ \\
\hline
\end{tabular}

Fonte: (Cotrim, 2006) 


\section{RESULTADOS E DISCUSSÃO}

A extração dos metais $\mathrm{Fe}, \mathrm{Al}, \mathrm{Zn}, \mathrm{Cr}, \mathrm{Cu}, \mathrm{Mn}$ e do elemento $\mathrm{P}$ foi realizada nas frações mais finas do sedimento (silte e argila, $<0,063 \mathrm{~mm}$ ), pois elementos traços estão associados principalmente nestas frações e pela semelhança granulométrica do material que é carreado em suspensão, sendo esta a forma mais importante de transporte para os sedimentos no ambiente aquático (Coringa, 2014).

Os resultados apresentados referem-se a amostras de sedimento superficial coletadas em agosto de 2011 no reservatório Guarapiranga em quatorze pontos amostrados. Todas as amostras foram submetidas ao processo de extração sequencial, cujo protocolo se encontra no item 5.2.

Com o método de extração sequencial, foi possível avaliar a distribuição dos elementos nas quatro frações geoquímicas distintas (Fração 1: ácido solúvel ou carbonatos; Fração 2: óxidos de Fe e Mn; Fração 3: matéria orgânica e Fração 4: Residual). As somas das três primeiras frações compõem a fração considerada biodisponível, enquanto que a diferença do total extraído representa a fração residual.

Os resultados referentes às concentrações de metais e fósforo biodisponíveis e residual extraídos dos sedimentos superficiais por meio da extração sequencial estão apresentados na Tabela 8.

Nas Figuras 14 a 17 encontram-se os resultados denominados de "pseudototal" (ou total), sendo considerado a soma das concentrações de todas as frações dos analitos presentes no sedimento (03 frações consideradas biodisponíveis mais a residual), deve-se levar em consideração que a fração residual representa o que está associado à matriz geológica e, neste, foi feito uma abertura total com ácidos fortes. 

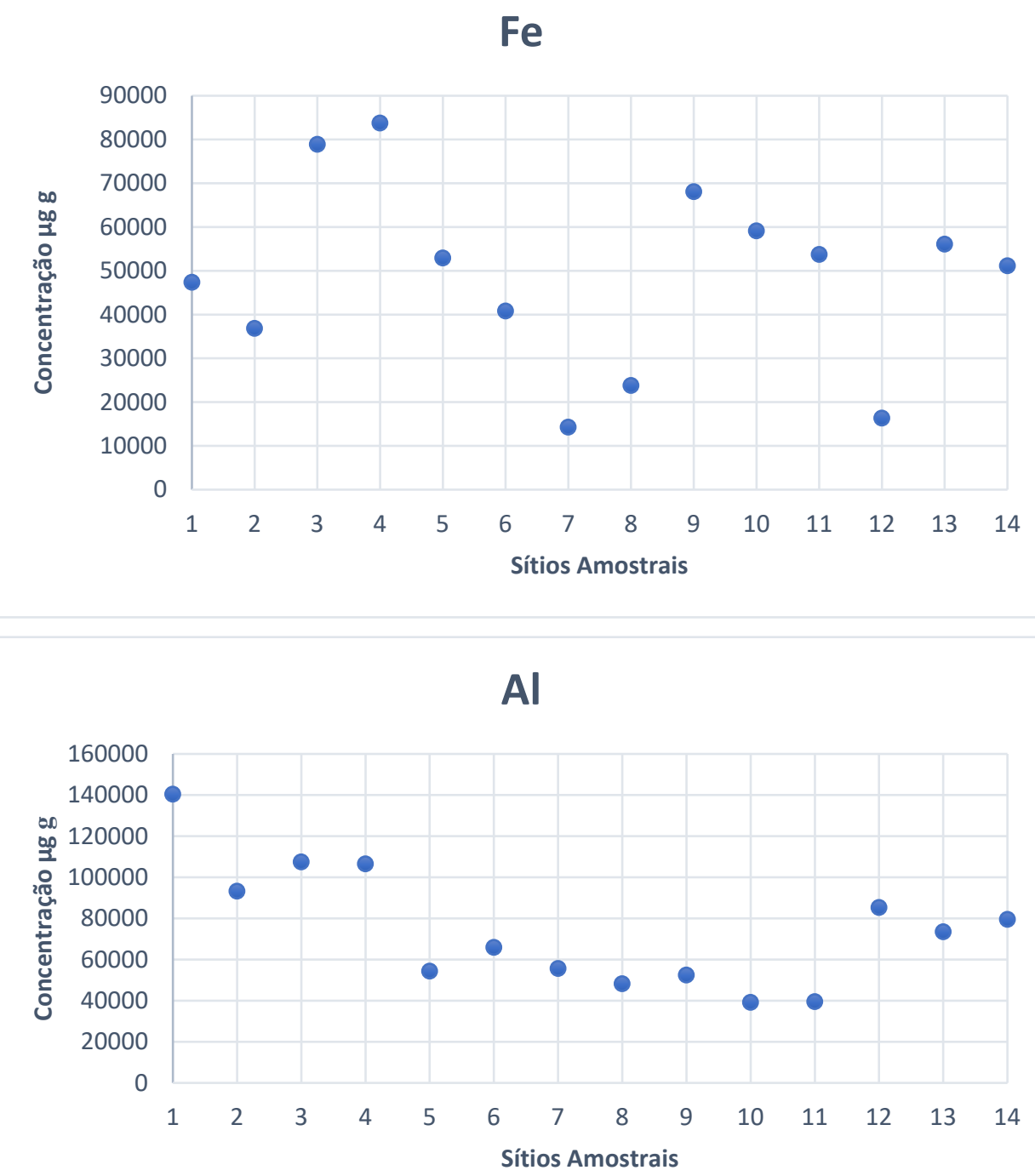

Figura 14. Distribuição espacial das concentrações "pseudototal" de Fe e Al presentes no sedimento superficial, ao longo dos pontos de coleta no reservatório Guarapiranga.

A distribuição das concentrações de Ferro total ou pseudototal nos sedimentos superficiais da represa pode ser observada na Figura 14, que também apresenta a distribuição da concentração de Al pseudototal no sedimento superficial. As maiores concentrações de alumínio encontram-se associadas aos minerais silicatos (fração 4) e estão homogeneamente distribuídas na área central da represa, com maiores concentrações nos sítios amostrais GU-01, GU-02, GU03 e GU-04 (1, 2, 3 e 4), locais mais preservados e com menor densidade 
ocupacional (conforme apresentado na Figura 8: Uso e ocupação da terra na região).

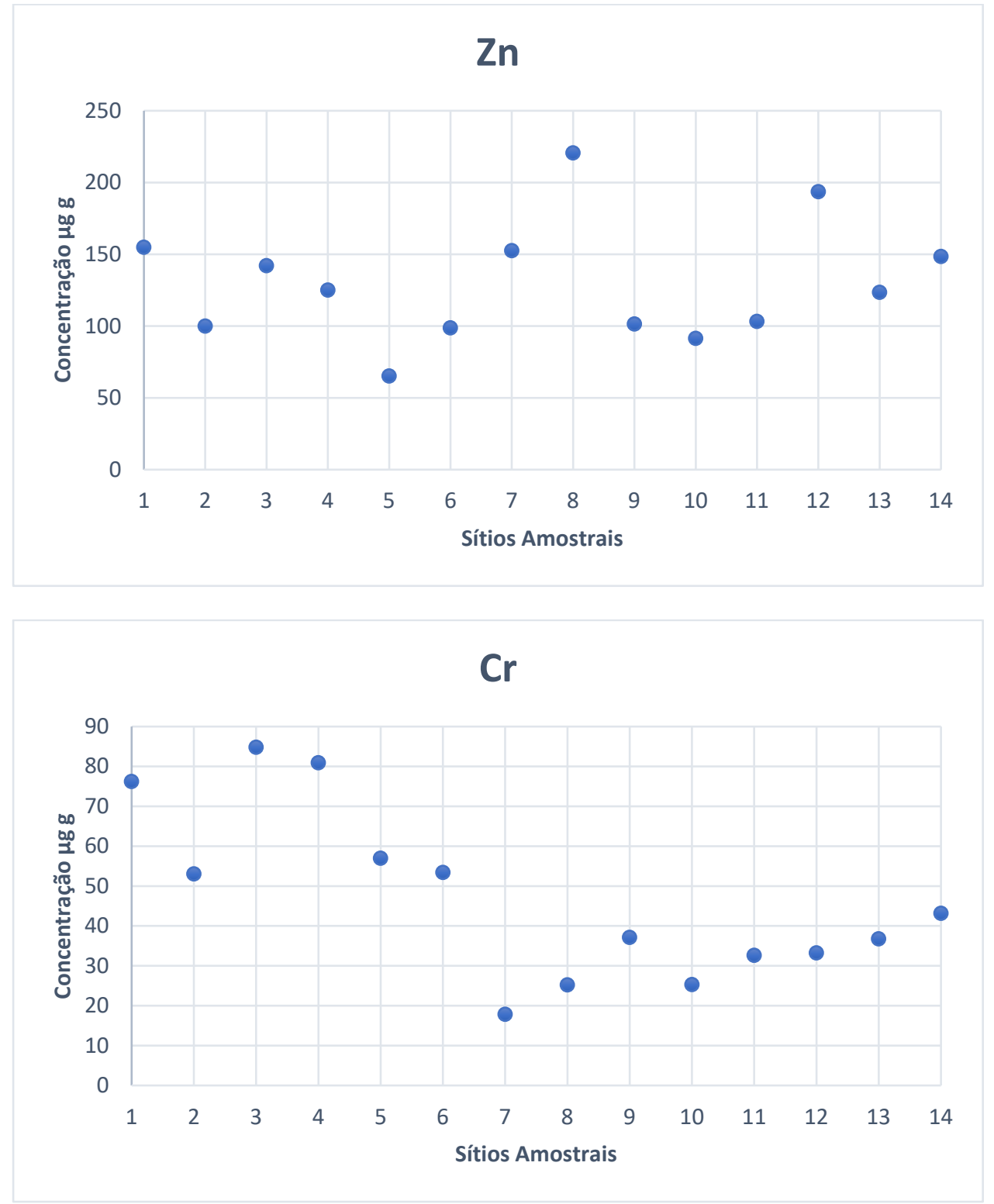

Figura 15. Distribuição espacial das concentrações "pseudototal" de $\mathrm{Zn}$ e $\mathrm{Cr}$ presentes no sedimento superficial, ao longo dos pontos de coleta no reservatório Guarapiranga.

Na Figura 15 é apresentada a distribuição da concentração pseudototal de Zinco e de Cromo no sedimento superficial. A concentração de crômio variou num intervalo de 17,83 a 84,81 $\mathrm{mg} \mathrm{Kg}^{-1}$, estando todas abaixo do PEL $(90 \mathrm{mg} \mathrm{Kg}$ ${ }^{-1}$ ), com maiores concentrações nos sítios amostrais GU-01, GU-02, GU-03 e GU- 
$04(1,2,3$ e 4), locais um pouco mais preservado e com menor densidade ocupacional (conforme apresentado na Figura 8: Uso e ocupação da terra na região).

A concentração de zinco apresentou variação de 65,13 a 220,48 mg kg-1 estando todos os pontos do reservatório com concentrações abaixo do estabelecido pelo PEL.
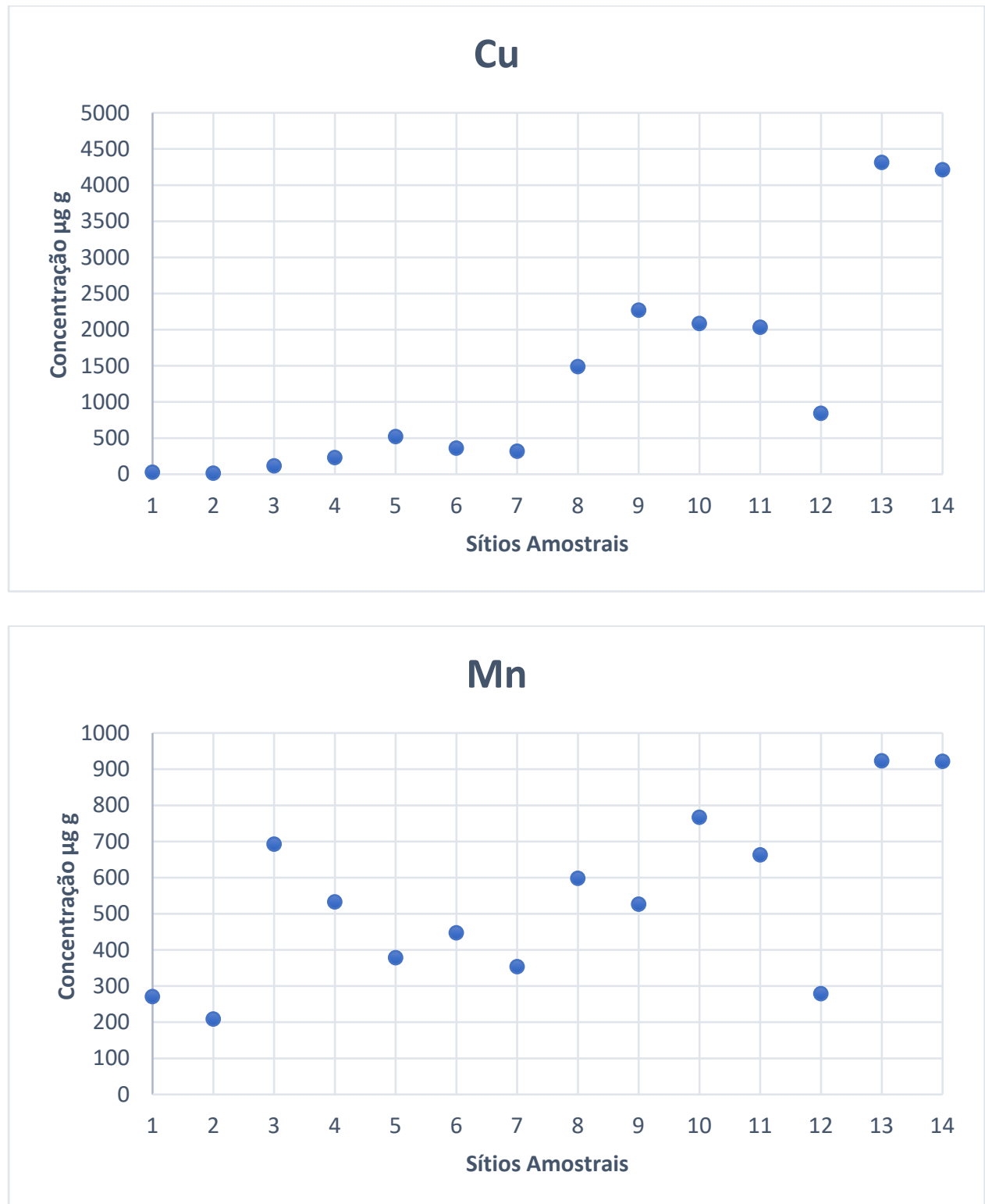

Figura 16. Distribuição espacial das concentrações "pseudototal" de $\mathrm{Cu}$ e $\mathrm{Mn}$ presentes no sedimento superficial, ao longo dos pontos de coleta no reservatório Guarapiranga. 
A distribuição das concentrações de cobre total ou pseudototal nos sedimentos superficiais da represa está apresentada na Figura 16. As concentrações observadas mostraram valores de enriquecimento a partir do sítio de amostragem GU-03 (3), com valor medio de $114,38 \mathrm{mg} \mathrm{Kg}^{-1}$, valores acima do TEL (35,7 $\mathrm{mg} \mathrm{Kg}^{-1}$ ) e, a partir do sítio de amostragem GU-04 (4), com valor medio de 229,64 $\mathrm{mg} \mathrm{Kg}^{-1}$, valores acima do PEL (197 $\mathrm{mg} \mathrm{Kg}^{-1}$ ).

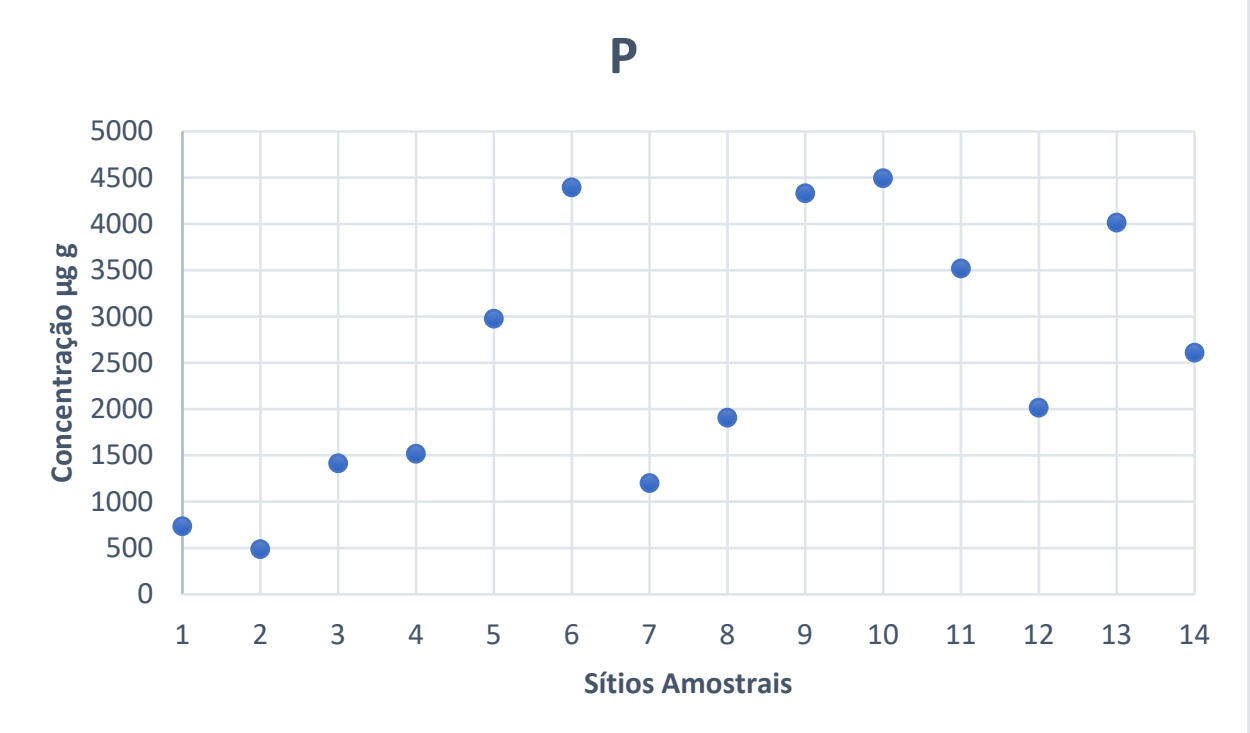

Figura 17. Distribuição espacial das concentrações "pseudototal" de Fósforo presentes no sedimento superficial, ao longo dos pontos de coleta no reservatório Guarapiranga.

A distribuição das concentrações de fósforo total ou pseudototal nos sedimentos superficiais da represa está apresentado na Figura 17. Os maiores valores ocorreram nos sítios de amostragem GU-09, GU-10 e GU-13 (9, 10 e 13). As regiões mais profundas da represa Guarapiranga apresentaram sedimento rico em fósforo. 
Tabela 8. Resultado da determinação dos metais $\mathrm{Fe}, \mathrm{Al}, \mathrm{Zn}, \mathrm{Cr}, \mathrm{Cu}, \mathrm{Mn}$ e do Fósforo, presentes nas amostras de sedimentos, coletados espacialmente nos 14 pontos do reservatório do Guarapiranga, obtidos após extração sequencial conforme protocolo descrito na tabela 5. ( $n=$ média de três determinações)

\begin{tabular}{|c|c|c|c|c|c|c|c|c|c|c|c|c|c|c|c|}
\hline \multirow[b]{2}{*}{ Elemento } & \multirow{2}{*}{$\begin{array}{c}\begin{array}{c}\text { Extração } \\
\text { sequencial }\end{array} \\
\text { Fração }\end{array}$} & \multicolumn{14}{|c|}{$\begin{array}{l}\text { Identificação dos Pontos de coleta no reservatório do Guarapiranga / } \\
\text { Concentração } \pm \operatorname{DPR}\left(\mu \mathrm{g} \mathrm{g}^{-1}\right)\end{array}$} \\
\hline & & GU-01 & GU-02 & GU-03 & GU-04 & GU-05 & GU-06 & GU-07 & GU-08 & GU-09 & GU-10 & GU-11 & GU-12 & GU-13 & GU-14 \\
\hline \multirow{5}{*}{$\mathrm{Fe}$} & - & $\pm 2,46$ & $\pm 2,82$ & $\pm 2,94$ & $\pm 8,11$ & $\pm 11,40$ & $\pm 17,30$ & $\pm 0,17$ & $\pm 1,27$ & $\pm 33,28$ & $\pm 31,83$ & $\pm 22,89$ & $\pm 27,38$ & $\pm 97,46$ & $\pm 40,10$ \\
\hline & \multirow[t]{2}{*}{2} & 4.477 & 4.674 & 17.657 & 22.063 & 22.180 & 22.900 & 5.143 & 17.009 & 33.618 & 31.064 & 32.504 & 1.489 & 31.370 & 24.545 \\
\hline & & \pm 367 & \pm 61 & \pm 2478 & \pm 618 & \pm 723 & \pm 955 & \pm 155 & \pm 837 & \pm 1206 & \pm 2115 & \pm 955 & \pm 80 & \pm 2793 & \pm 649 \\
\hline & \multirow[t]{2}{*}{4} & 35.224 & 26.975 & 47.452 & 41.805 & 9.654 & 6.006 & 6.799 & 6.349 & 30.802 & 24.920 & 18.700 & 13.664 & 20.896 & 24.517 \\
\hline & & \pm 1571 & \pm 1696 & \pm 2611 & \pm 3319 & \pm 163 & \pm 178 & \pm 399 & \pm 621 & \pm 2969 & \pm 2615 & \pm 1198 & \pm 686 & \pm 576 & \pm 1804 \\
\hline \multicolumn{2}{|c|}{$\begin{array}{c}\text { Pseudototal } \\
\text { (biodisponível +residual) }\end{array}$} & 47.325 & 36.823 & 78.843 & 83.728 & 52.899 & 40.778 & 14.234 & 23.771 & 68.030 & 59.105 & 53.703 & 16.322 & 56.048 & 51.097 \\
\hline \multirow[t]{4}{*}{$\mathrm{Al}$} & 1 & 108,54 & 68,65 & 30,76 & 70,14 & 72,78 & 984,14 & 55,08 & 94,44 & 317,93 & 174,76 & 298,58 & 138,39 & 356,65 & 256,55 \\
\hline & 3 & \pm 175 & \pm 213 & \pm 135 & \pm 278 & \pm 303 & \pm 176 & \pm 98 & \pm 236 & \pm 700 & \pm 363 & \pm 551 & \pm 428 & \pm 461 & \pm 355 \\
\hline & \multirow[t]{2}{*}{4} & 130.186 & 87.229 & 97.940 & 95.548 & 46.007 & 55.630 & 48.194 & 41.228 & 43.228 & 31.632 & 31.885 & 77.793 & 63.517 & 68.967 \\
\hline & & \pm 6900 & \pm 5062 & \pm 4410 & \pm 8221 & \pm 1688 & \pm 4110 & \pm 3592 & \pm 5199 & \pm 4188 & \pm 2255 & \pm 3881 & \pm 4797 & \pm 2658 & \pm 7639 \\
\hline \multicolumn{2}{|c|}{$\begin{array}{c}\text { Pseudototal } \\
\text { (biodisponível +residual) }\end{array}$} & 140.288 & 93.167 & 107.372 & 106.403 & 54.276 & 65.823 & 55.570 & 48.109 & 52.374 & 39.107 & 39.397 & 85.203 & 73.417 & 79.407 \\
\hline
\end{tabular}




\begin{tabular}{|c|c|c|c|c|c|c|c|c|c|c|c|c|c|c|c|}
\hline Elemento & ração & GU-01 & GU-02 & GU-03 & GU-04 & GU-05 & GU-06 & GU-07 & GU-08 & GU-09 & GU-10 & GU-11 & GU-12 & GU-13 & GU-14 \\
\hline \multirow[t]{6}{*}{$\mathrm{Zn}$} & \multirow[t]{2}{*}{1} & 14,57 & 8,68 & 5,02 & 17,65 & 13,17 & 55,00 & 31,86 & 93,10 & 39,82 & 37,03 & 43,60 & 78,11 & 65,42 & 70,15 \\
\hline & & $\pm 1,48$ & $\pm 0,64$ & $\pm 0,45$ & $\pm 0,86$ & $\pm 0,26$ & $\pm 4,03$ & $\pm 1,16$ & $\pm 12,08$ & $\pm 3,42$ & $\pm 2,57$ & $\pm 2,46$ & $\pm 8,55$ & $\pm 2,68$ & $\pm 5,21$ \\
\hline & 2 & 58,90 & 39,35 & 42,57 & 25,35 & 14,04 & 14,88 & 72,04 & 87,88 & 17,77 & 22,64 & 18,23 & 66,62 & 20,97 & 34,70 \\
\hline & \multirow[t]{2}{*}{3} & 37,03 & 17,17 & 31,87 & 25,26 & 16,07 & 11,45 & 26,82 & 16,09 & 9,87 & 5,41 & 7,55 & 16,15 & 10,16 & 13,37 \\
\hline & & $\pm 0,6$ & $\pm 0,42$ & $\pm 2,02$ & $\pm 2,01$ & $\pm 1,40$ & $\pm 0,32$ & $\pm 2,03$ & $\pm 1,46$ & $\pm 0,89$ & $\pm 0,55$ & $\pm 0,68$ & $\pm 1,89$ & $\pm 0,70$ & $\pm 0,66$ \\
\hline & 4 & 44,31 & 34,61 & 62,47 & 56,69 & 21,85 & 17,32 & 21,69 & 23,41 & 33,92 & 26,27 & 33,79 & 32,66 & 26,88 & 30,11 \\
\hline
\end{tabular}

\begin{tabular}{|c|c|c|c|c|c|c|c|c|c|c|c|c|c|c|c|}
\hline $\mathrm{Cr}$ & \multirow[t]{2}{*}{1} & $<$ L.D. & $<$ L.D. & $<$ L.D. & $<$ L.D. & < L.D. & $<$ L.D. & $<$ L.D. & $<$ L.D. & $<$ L.D. & $<$ L.D. & $<$ L.D. & $<$ L.D. & $<$ L.D. & $<$ L.D. \\
\hline & & - & - & - & - & - & - & - & - & - & - & - & - & - & - \\
\hline & \multirow[t]{2}{*}{2} & 1,50 & 1,24 & 1,26 & 1,73 & 1,40 & 4,19 & 2,15 & 6,61 & 6,25 & 3,70 & 7,22 & 5,19 & 6,42 & 7,73 \\
\hline & & $\pm 0,20$ & $\pm 0,06$ & $\pm 0,08$ & $\pm 0,16$ & $\pm 0,01$ & $\pm 0,21$ & $\pm 0,08$ & $\pm 0,17$ & $\pm 0,46$ & $\pm 0,39$ & $\pm 0,76$ & $\pm 0,20$ & $\pm 0,41$ & $\pm 0,26$ \\
\hline & 3 & $\pm 0,3$ & $\pm 0,57$ & $\pm 1,07$ & $\pm 1,08$ & $\pm 0,59$ & $\pm 0,34$ & $\pm 0,33$ & $\pm 0,07$ & $\pm 0,63$ & $\pm 0,50$ & $\pm 0,86$ & $\pm 1,05$ & $\pm 0,93$ & $\pm 0,85$ \\
\hline & \multirow[t]{2}{*}{4} & 56,38 & 41,28 & 69,36 & 65,39 & 42,43 & 33,77 & 4,70 & 2,72 & 17,51 & 12,65 & 13,68 & 14,84 & 16,90 & 19,61 \\
\hline & & $\pm 0,67$ & $\pm 4,96$ & $\pm 5,32$ & $\pm 3,29$ & $\pm 1,59$ & $\pm 2,02$ & $\pm 0,36$ & $\pm 0,32$ & $\pm 1,68$ & $\pm 1,11$ & $\pm 1,87$ & $\pm 0,43$ & $\pm 0,60$ & $\pm 2,05$ \\
\hline
\end{tabular}




\begin{tabular}{|c|c|c|c|c|c|c|c|c|c|c|c|c|c|c|c|}
\hline Elemento & \multirow{3}{*}{$\begin{array}{c}\text { Fração } \\
1\end{array}$} & GU-01 & U-02 & GU-03 & GU-04 & GU-05 & GU-06 & GU-07 & GU-08 & GU-09 & GU-10 & GU-11 & GU-12 & GU-13 & GU-14 \\
\hline \multirow[t]{6}{*}{$\mathrm{Cu}$} & & 0,20 & 0 & 0,10 & 4,31 & 31,19 & 60,69 & 17,08 & 223,40 & 719,60 & 418,90 & 690,48 & 97,68 & 1566 & 912,90 \\
\hline & & $\pm 0,01$ & $\pm 0,01$ & $\pm 0,01$ & $\pm 0,46$ & $\pm 0,98$ & $\pm 7,03$ & $\pm 0,87$ & $\pm 8,07$ & $\pm 67,86$ & $\pm 23,19$ & $\pm 40,37$ & $\pm 3,89$ & \pm 33 & $\pm 59,28$ \\
\hline & 2 & 2,10 & 1,64 & 13,53 & 30,26 & 111,31 & 99,22 & 126,06 & 882,38 & 913,88 & 1.086 & 828,41 & 453,73 & 1.516 & 1.943 \\
\hline & \multirow[t]{2}{*}{3} & 10,53 & 7,13 & 60,35 & 127,34 & 301,79 & 159,72 & 131,31 & 324,22 & 556,91 & 537,54 & 456,70 & 259,05 & 1.093 & 1.280 \\
\hline & & $\pm 2,5$ & $\pm 0,21$ & $\pm 3,82$ & $\pm 9,13$ & $\pm 4,87$ & $\pm 5,11$ & $\pm 6,01$ & $\pm 5,22$ & $\pm 29,52$ & $\pm 28,06$ & $\pm 35,20$ & $\pm 26,96$ & $\pm 68,17$ & \pm 47 \\
\hline & 4 & 13,73 & 6,09 & 40,40 & 67,73 & 75,95 & 42,12 & 43,71 & 58,42 & 79,81 & 43,24 & 56,97 & 32,21 & 137,47 & 77,04 \\
\hline
\end{tabular}

\begin{tabular}{|c|c|c|c|c|c|c|c|c|c|c|c|c|c|c|c|}
\hline \multirow[t]{7}{*}{$\mathrm{Mn}$} & \multirow[t]{2}{*}{1} & 100,45 & 45,71 & 178,81 & 335,03 & 252,22 & 356,35 & 56,35 & 305,41 & 399,13 & 603,94 & 534,35 & 143,21 & 771,62 & 725,16 \\
\hline & & $\pm 4,61$ & $\pm 1,58$ & $\pm 2,69$ & $\pm 12,22$ & $\pm 6,78$ & $\pm 31,36$ & $\pm 0,98$ & $\pm 32,53$ & $\pm 39,95$ & $\pm 19,14$ & $\pm 24,49$ & $\pm 6,87$ & $\pm 37,21$ & $\pm 34,57$ \\
\hline & \multirow[t]{2}{*}{2} & 28,93 & 17,44 & 285,46 & 59,40 & 56,80 & 44,20 & 193,12 & 226,96 & 47,56 & 111,11 & 52,19 & 56,77 & 85,80 & 119,19 \\
\hline & & $\pm 2,58$ & $\pm 1,46$ & $\pm 26,61$ & $\pm 3,31$ & $\pm 0,86$ & $\pm 4,16$ & $\pm 11,31$ & $\pm 14,35$ & $\pm 0,35$ & $\pm 8,87$ & $\pm 0,55$ & $\pm 3,64$ & $\pm 3,81$ & $\pm 16,63$ \\
\hline & 3 & $\pm 2,5$ & $\pm 1,47$ & $\pm 6,20$ & $\pm 3,05$ & $\pm 1,24$ & $\pm 0,38$ & $\pm 1,22$ & $\pm 0,72$ & $\pm 1,41$ & $\pm 0,92$ & $\pm 1,00$ & $\pm 1,11$ & $\pm 0,76$ & $\pm 2,04$ \\
\hline & \multirow[t]{2}{*}{4} & 120,01 & 123,83 & 136,71 & 106,37 & 45,90 & 35,81 & 73,30 & 56,70 & 67,30 & 42,67 & 64,93 & 67,55 & 50,03 & 61,58 \\
\hline & & $\pm 0,60$ & $\pm 16,76$ & $\pm 8,80$ & $\pm 4,90$ & $\pm 2,06$ & $\pm 3,64$ & $\pm 5,47$ & $\pm 5,82$ & $\pm 5,80$ & $\pm 1,46$ & $\pm 5,97$ & $\pm 3,41$ & $\pm 0,65$ & $\pm 3,81$ \\
\hline
\end{tabular}




\begin{tabular}{|c|c|c|c|c|c|c|c|c|c|c|c|c|c|c|c|}
\hline Elemento & ração & GU-01 & GU-02 & GU-03 & GU-04 & GU-05 & GU-06 & GU-07 & GU-08 & GU-09 & GU-10 & GU-11 & GU-12 & GU-13 & GU-14 \\
\hline \multirow[t]{6}{*}{$P$} & \multirow[t]{2}{*}{, } & 3,31 & 3,36 & 4,92 & 4,38 & 4,67 & 10,85 & 17,58 & 3,64 & 4,29 & 11,54 & 3,40 & 8,38 & 3,16 & 6,23 \\
\hline & & $\pm 0,15$ & $\pm 0,07$ & $\pm 0,20$ & $\pm 0,38$ & $\pm 0,41$ & $\pm 0,07$ & $\pm 1,24$ & $\pm 0,30$ & $\pm 0,27$ & $\pm 0,17$ & $\pm 0,05$ & $\pm 0,82$ & $\pm 0,40$ & $\pm 0,30$ \\
\hline & 2 & 33,94 & 17,55 & 43,18 & 56,95 & 194,73 & 978,01 & 475,00 & 1043 & 1867 & 1638 & 1421 & 614,76 & 2548 & 1441 \\
\hline & \multirow[t]{2}{*}{3} & 275,90 & 157,03 & 252,32 & 366,79 & 693,63 & 1529 & 349,07 & 235,33 & 746,48 & 368,12 & 376,93 & 263,47 & 645,87 & 346,10 \\
\hline & & $\pm 19,2$ & $\pm 6,22$ & $\pm 41,90$ & $\pm 14,43$ & $\pm 49,90$ & \pm 48 & $\pm 7,89$ & $\pm 4,75$ & $\pm 48,96$ & $\pm 44,17$ & $\pm 37,35$ & $\pm 27,69$ & $\pm 68,93$ & $\pm 22,64$ \\
\hline & 4 & 421,30 & 309,83 & 1.114 & 1.090 & 2.084 & 1.876 & 357,52 & 623,95 & 1.714 & 2.476 & 1.717 & 1.129 & 816,64 & 815,36 \\
\hline
\end{tabular}




\subsection{Concentração, distribuição e disponibilidade dos metais $\mathrm{Fe}, \mathrm{Al}, \mathrm{Zn}, \mathrm{Cr}, \mathrm{Cu}$ e Mn e do elemento Fósforo nas frações do sedimento}

Os solos tropicais do Estado de São Paulo possuem concentrações naturalmente elevadas dos metais Alumínio, Ferro e Manganês. Dessa forma, os solos constituem-se em uma fonte significativa desses metais para os corpos hídricos, por meio de arraste de partículas e matéria orgânica devido a processos erosivos intensificados, dentre outros fatores, por chuvas intensas e carência/ausência de cobertura vegetal. Os metais Zinco, Cromo e Cobre dissolvidos muitas vezes estão associados aos lançamentos de efluentes industriais (CETESB, 2014).

Nos sedimentos, os metais traços podem existir em diferentes formas químicas. Em compartimentos mais preservados da ação antrópica, a ligação dos metais traços ocorrem principalmente à base de silicatos e, desta forma, possuem menor mobilidade. Quando o compartimento sofre ação antrópica com a inclusão de elementos químicos, estes que foram sendo introduzidos apresentam maior mobilidade, pois estão ligados a outras fases do sedimento, como carbonatos, óxidos, hidróxidos e sulfetos (Pereira et al., 2007).

A extração sequencial foi realizada nas frações mais finas do sedimento $(<0,063 \mathrm{~mm})$, o uso desta granulometria ocorre pois em geral os elementos traços estão associados principalmente às partículas de silte e argila, e, esta fração é a que mais se assemelha à granulometria do material carreado em suspensão no ambiente aquático (Coringa, 2016).

A distribuição dos elementos estudados nas diferentes fases do sedimento mostra-se importante no entendimento da forma pela qual estão associados e sua mobilidade aos fatores que estão expostos (Coringa, 2014).

A extração sequencial seletiva, resultados apresentados na Tabela 8, permitiu avaliar a distribuição dos elementos traços e majoritários de acordo com as frações geoquímicas associadas principalmente às fases biodisponível e residual, procurando dar subsídios ao estudo das interações, redistribuições e destino desses metais nos sedimentos aquáticos. 
A Fração 1, ácido solúvel ligada a carbonatos, envolve a liberação de metais fracamente ligados (metais lábeis) onde uma simples mudança de $\mathrm{pH}$ pode acarretar nesta dessorção.

Os metais ligados a esta fração trocável, são de grande interesse ambiental, pois foram introduzidos pelas atividades antrópicas, quando os valores obtidos nesta fração estão elevados, há indícios de alto grau de impacto naquele ponto amostrado (Pereira et al., 2007; Okoro et al., 2012; Coringa, 2014).

Neste estudo, a contribuição da fração trocável não foi expressiva para a maioria dos elementos, com exceção do $\mathrm{Mn}$ que apresentou homogeneidade em todos os sítios amostrados, e Cu que nos sítios mais a jusante, apresentou maior mobilidade quando comparados aos sítios à montante.

A Fração 2, redutível a óxidos de ferro e manganês, os metais ligados a óxidos de Fe e Mn são particularmente susceptíveis a condições anóxicas (redutoras), nesta fração, é possível verificar que Fe e Al foram os elementos que apresentaram as maiores concentrações de extração, principalmente nos pontos GU-09 > GU-11 > GU-13 > GU-10 para Fe e GU-14 > GU-13 > GU-08 > GU-12 para Al.

A Fração 3, oxidável ligada a matéria orgânica, foi possível verificar que os elementos com mais extração foram Fe sendo GU-05 > GU-04 > GU-03 > GU-06 > GU > 01 e para Al GU-04 > GU-01 > GU-03 > GU-06 > GU-05.

A Fração 4, residual, extrai os metais do retículo cristalino do sedimento e é alcançada por meio da digestão com ácidos fortes. Nesta fase, todos os metais e o elemento $\mathrm{P}$ obtiveram concentrações elevadas de extração, quando comparada às concentrações das frações anteriores.

As concentrações dos metais e fósforo nas frações geoquímicas dos sedimentos obtidas pela extração sequencial, indicam que os sedimentos do reservatório Guarapiranga concentram os elementos na sequência: Fe $>$ Al $>$ P > $\mathrm{Mn}>\mathrm{Zn}>\mathrm{Cr}>\mathrm{Cu}$. 
A distribuição dos teores dos metais e de fósforo nas diferentes fases do sedimento é importante para se entender a forma pela qual se encontram associados e, assim, indicar sua mobilidade e os fatores que estão influenciando essas mudanças.

\subsubsection{Elemento Fe}

O metal ferro faz parte da geoquímica natural de solos e sedimentos e é um dos principais elementos para a manutenção do equilíbrio da biota aquática (Silva, 2016).

A Figura 18 apresenta uma comparação da distribuição percentual (\%) relativa à concentração de $F e$ nas principais frações (F1, F2, F3 e F4) nos sedimentos superficiais amostrados no reservatório Guarapiranga.

Avaliando os resultados apresentados, observa-se uma maior extração da fração 1 trocável nos pontos amostrados GU-12 > GU-13 > GU-14. Para a fração 2, óxidos de Fe e Mn, a concentração de Fe foi bem elevada principalmente para os pontos de amostragem GU-08 > GU-11 > GU-13, entretanto a concentração foi baixa nos pontos de amostragem GU-01 e GU-12. A extração mais expressiva ocorreu na fração matéria orgânica, principalmente para os pontos de amostragem GU-04 e GU-05. As amostras provenientes dos pontos de amostragem GU-08 e GU-14 apresentou pouca mobilidade em relação aos outros pontos amostrados.

Para a fração residual, verifica-se que o metal Fe apresentou maior mobilidade nos pontos de amostragem GU-12 > GU-01 > GU-02. Nos pontos de amostragem GU-05 e GU-06 os resultados obtidos foram pouco expressivos quando comparados aos demais pontos amostrados. A partir da estação amostral GU 6, observa-se que praticamente $50 \%$ do Fe está associado às frações trocáveis (F1, F2 e F3). 


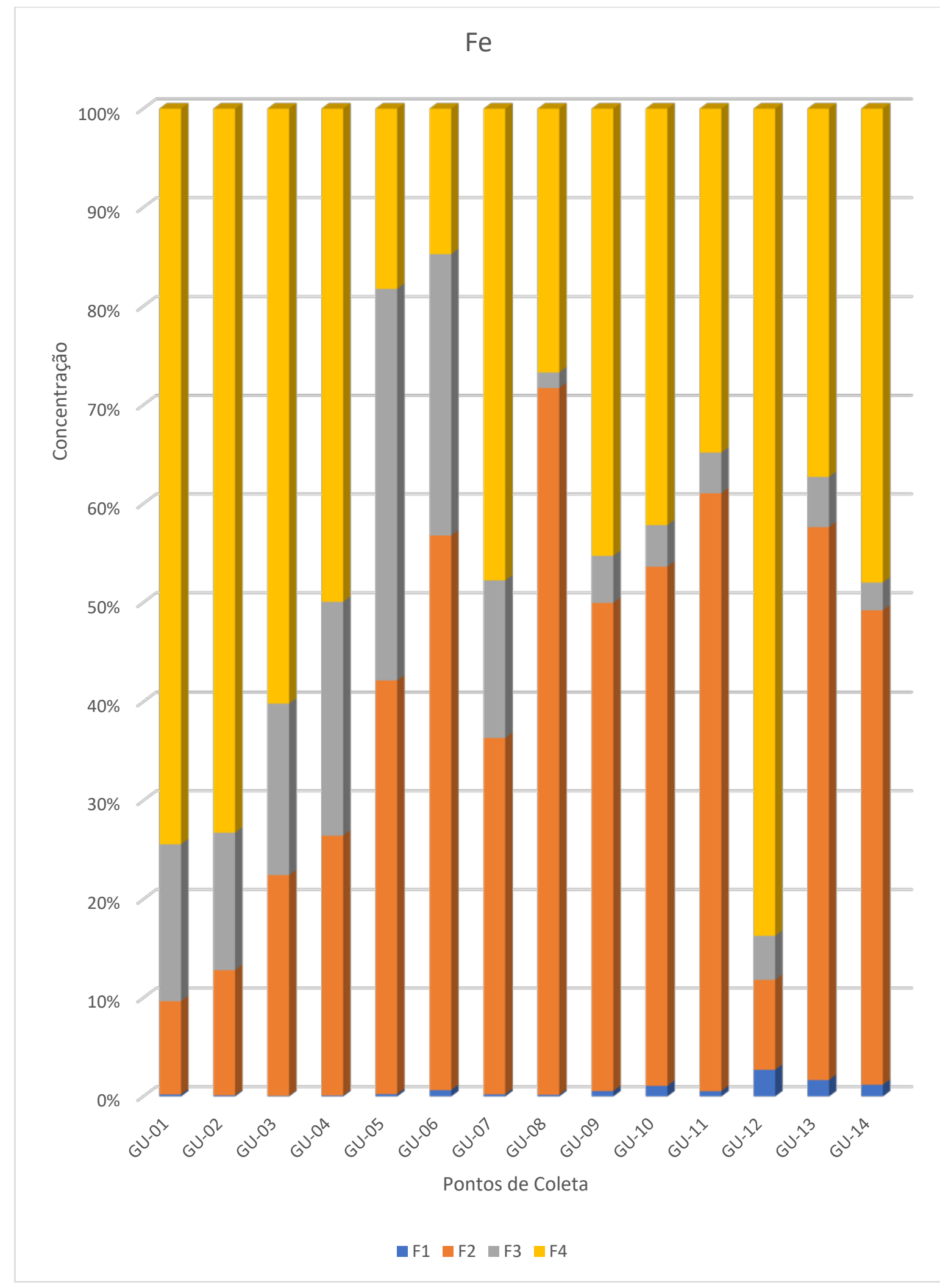

Figura 18: Distribuição percentual de Fe nas principais frações (F1, F2, F3 e F4) nos sedimentos superficiais amostrados no reservatório Guarapiranga. 


\subsubsection{Elemento Al}

O percentual de distribuição do Alumínio nas principais frações (F1, F2, F3 e F4), nos sedimentos superficiais amostrados no reservatório Guarapiranga, está apresentado na Figura 19. O Al foi o elemento que apresentou maiores concentrações quanto ao valor "pseudototal". Quando comparado com os outros elementos, apresenta uma distribuição mais homogênea no reservatório, sendo que sua fração mais representativa está associada aos minerais silicatos.

Na Fração 1, trocável, os resultados foram pouco expressivos, a maior extração ficou evidenciada no ponto de amostragem GU-06. Para a fração 2, redutível a óxidos de Fe e Mn, as concentrações ficaram mais evidenciadas a partir do ponto de amostragem GU-08 e seguindo para jusante (barragem) do reservatório, sendo que nos pontos GU-10 e GU-11 foram mais expressivos para esta fração.

O Al apresentou biodisponibilidade principalmente associado a matéria orgânica (Fração 3), sugerindo um caráter de biodisponibilidade ao ambiente.

Os resultados evidenciam que Al faz parte da formação geológica natural do sedimento. Embora seja expressivo o valor da somatória das 4 frações, o alumínio não está preferencialmente associado à fração redutível, que é a mais lábil, e sim na fração residual que é a fração que possui menor potencial de mobilidade. 


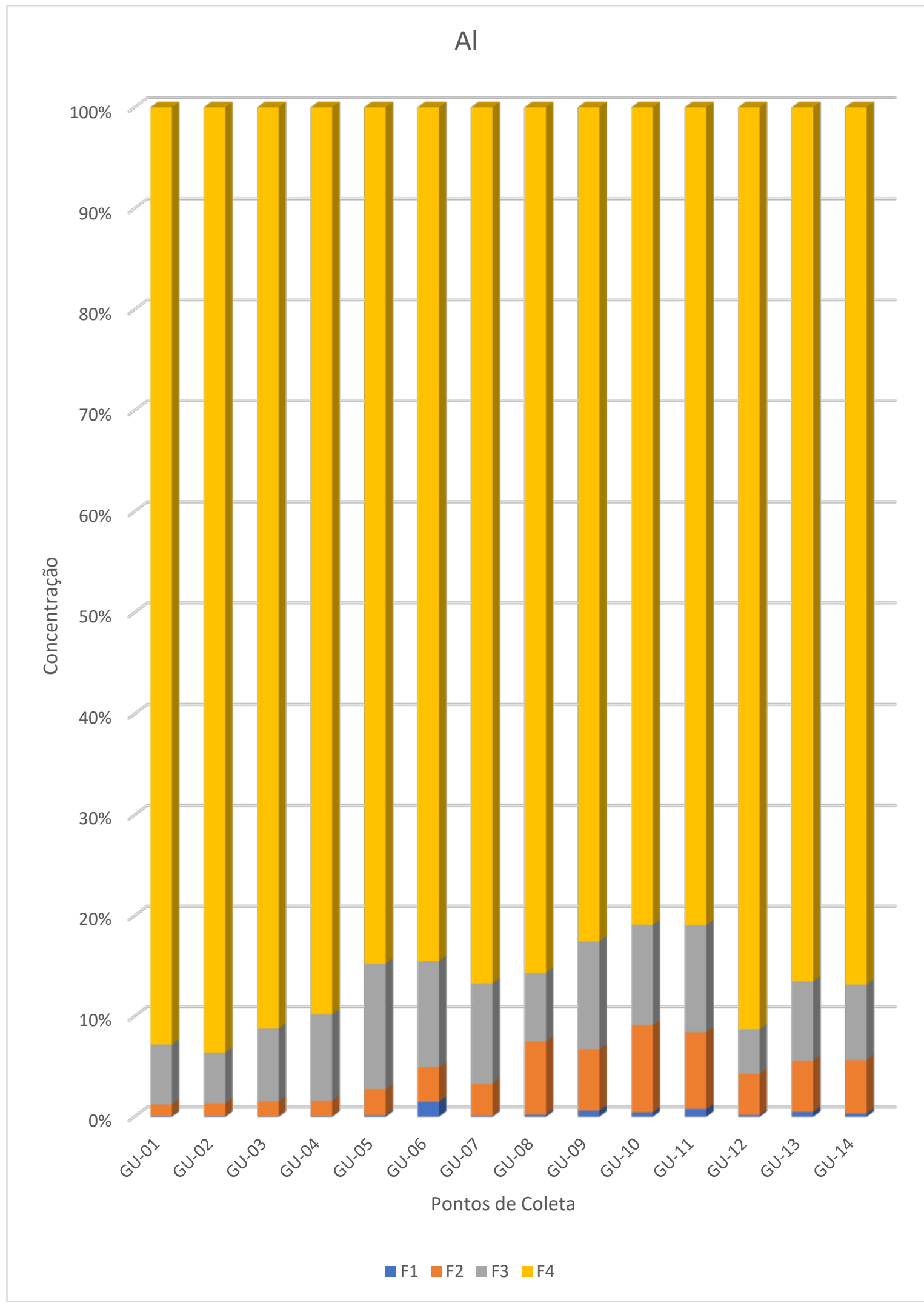

Figura 19: Distribuição percentual do Al nas principais frações (F1, F2, F3 e F4) nos sedimentos superficiais amostrados no reservatório Guarapiranga. 
Entretanto, as concentrações de alumínio e pH precisam ser tratadas com especial cuidado, pois este metal é utilizado no processo de tratamento da água potável e é despejado diretamente na barragem. Por este motivo, o pH da água deve ser mantido em níveis superiores a 5 e inferior a 9, uma vez que a remobilização do alumínio para a coluna d'água pode constituir uma ameaça para a população e pode, em última análise, influenciar as propriedades neurotóxicas (Souza, 2013).

\subsubsection{Elemento $\mathrm{Zn}$}

A Figura 20 apresenta o percentual de distribuição de Zn nas principais frações (F1, F2, F3 e F4) nos sedimentos superficiais amostrados. Foi possível verificar que o metal $\mathrm{Zn}$ no reservatório apresentou maior enriquecimento na fase biodisponível do que na fração residual quando comparado às quatro extrações. $A$ presença deste metal na fase biodisponível indica uma possível contaminação de origem antrópica no reservatório.

Para a fração 1, trocável, o Zn apresentou maior enriquecimento nos pontos de amostragem GU-06 > GU-13 > GU-14, sendo possível observar uma tendência de montante a jusante para o zinco na fração trocável.

Na fração 2 redutível a óxidos de Fe e Mn os pontos de amostragem GU-08 $>$ GU-07 > GU-12 > GU-01 foram os locais em que o Zn estava mais evidenciado e na fração 3, oxidável ligada a matéria orgânica, os pontos de amostragem GU-01 e GU-03 foram os que apresentarem os valores mais elevados.

Na fração 4, residual, a concentração de zinco foi baixa quando comparada às três extrações anteriores, indicando que o zinco não é um elemento da constituição da matriz geológica do sedimento.

A maior concentração de zinco na fase lábil dentro do reservatório ocorre na região próxima à transposição da Billings. Este metal possivelmente entra no corpo d'água pela lavagem da bacia de drenagem pelas chuvas, por efluentes não tratados e disposição incorreta de resíduos contendo o metal (Lage, 2013). 


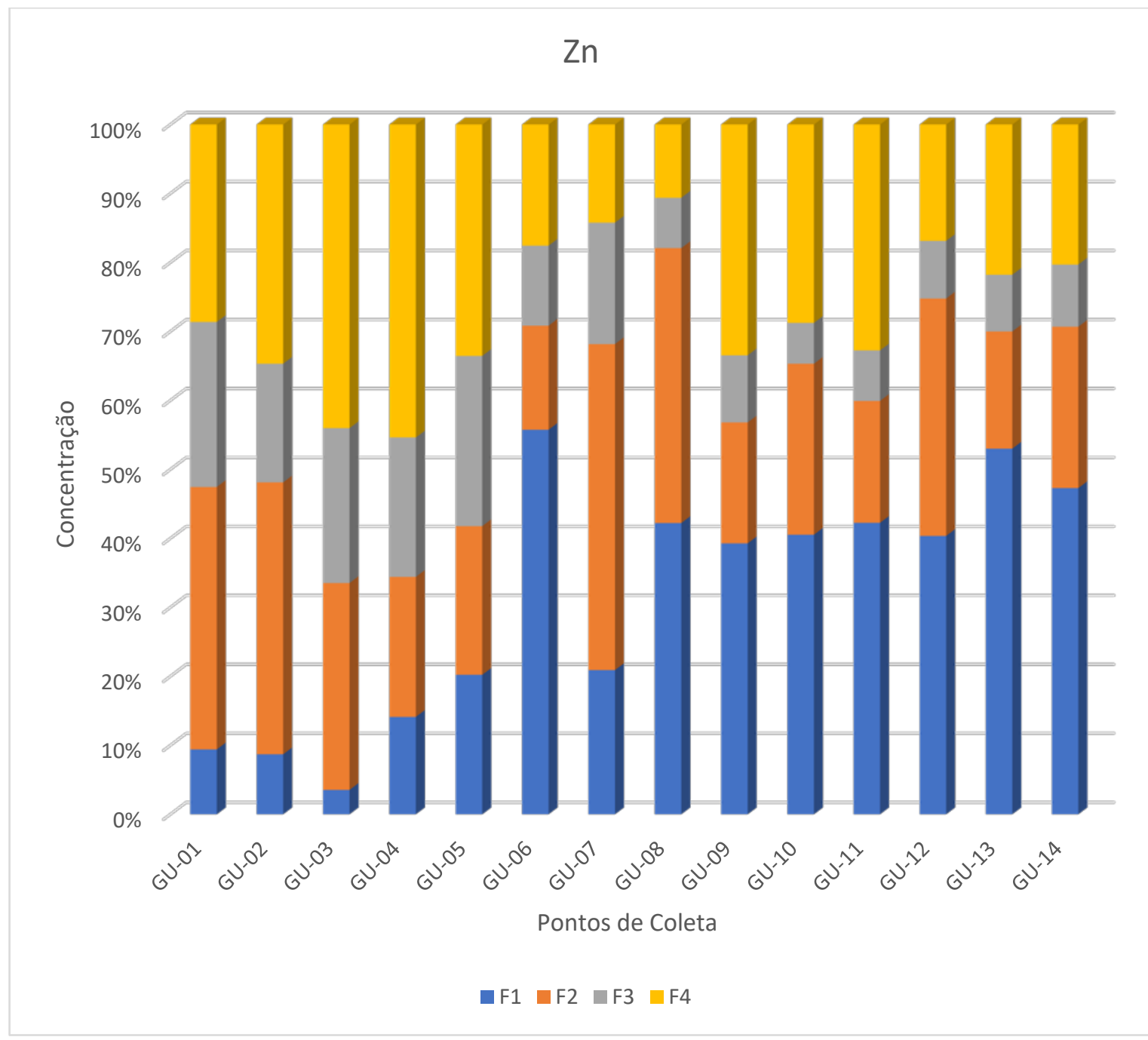

Figura 20: Distribuição percentual do Zn nas principais frações (F1, F2, F3 e F4) nos sedimentos superficiais amostrados no reservatório Guarapiranga.

\subsubsection{Elemento $\mathrm{Cr}$}

A Figura 21 apresenta a distribuição percentual de $\mathrm{Cr}$ tanto na fase biodisponível quanto na fase residual. Foi possível verificar que na, fração 1 , trocável, a concentração de $\mathrm{Cr}$ ficou abaixo do limite de detecção.

$\mathrm{Na}$ fração 2, redutível a óxidos de $\mathrm{Fe}$ e $\mathrm{Mn}, \mathrm{o} \mathrm{Cr}$ apresentou um enriquecimento nas amostras a partir do ponto de amostragem GU-06 até GU-14, indicando esta tendência a montante (barragem) do reservatório.

Uma concentração expressiva foi apresentada na fração 3 oxidável, ligada a matéria orgânica, principalmente no ponto de amostragem GU-07 e GU-08 
apresentando elevada na fase biodisponível, correspondendo a mais de $60 \%$ da composição da amostra. Estes valores de concentração para $\mathrm{Cr}$ possivelmente estão associados a efluentes industriais clandestinos (galvânicas, por exemplo) despejados no reservatório.

$\mathrm{Na}$ fração 4 residual o $\mathrm{Cr}$ apresentou maior enriquecimento nos pontos de amostragem GU-01 até GU-06 e a partir do GU-07 até a montante, houve significativa redução na concentração dos valores extraídos.

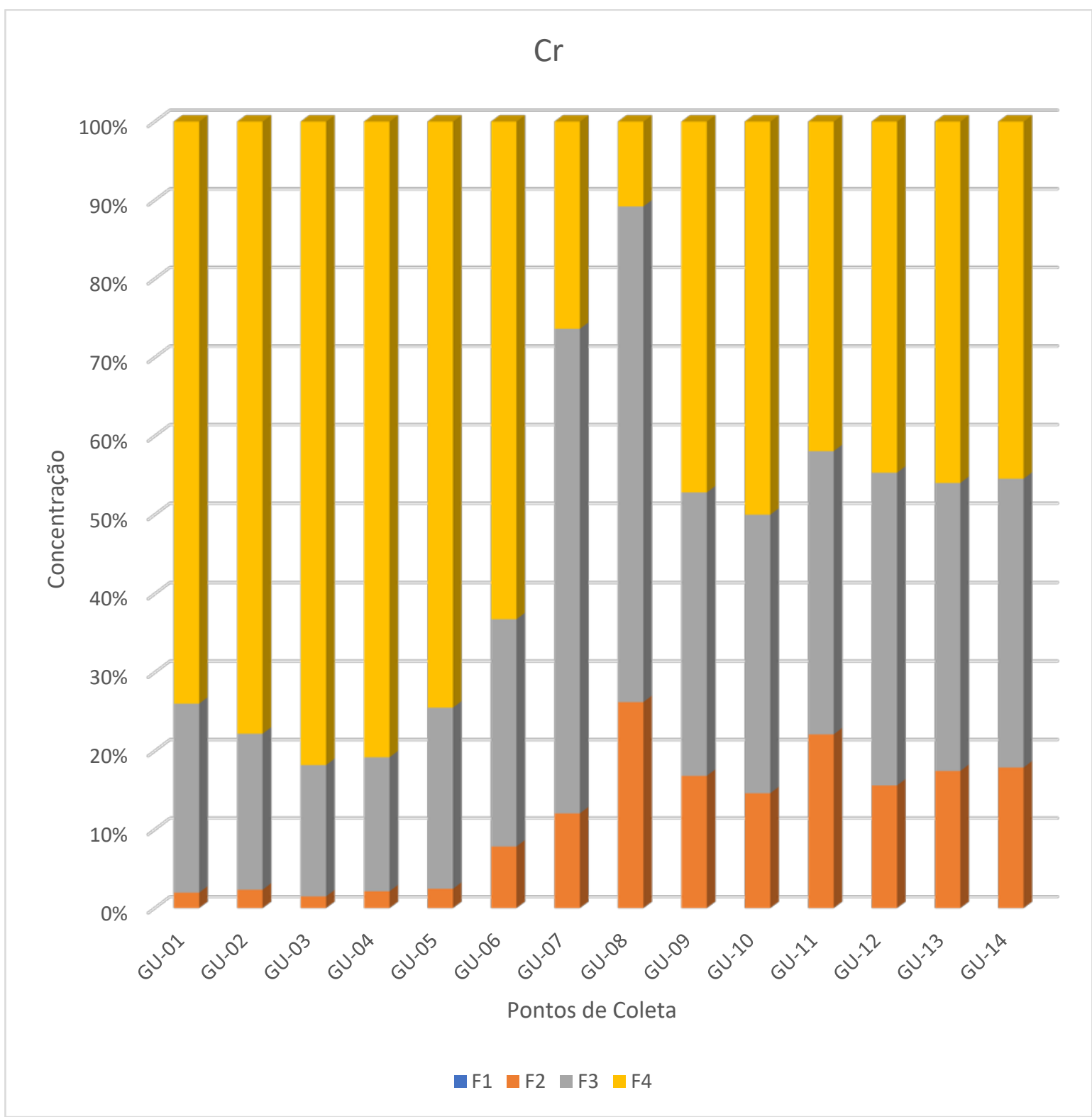

Figura 21: Distribuição do percentual de Cr nas principais frações (F1, F2, F3 e F4) nos sedimentos superficiais amostrados no reservatório Guarapiranga. 


\subsubsection{Elemento $\mathrm{Cu}$}

A Figura 22 representa os resultados da distribuição percentual de Cu tanto nas frações (F1, F2, F3 e F4) analisadas nas amostras de sedimento superficiais do reservatório. Os resultados indicam que o Cu apresentou maior concentração na fração 1 (trocável) a partir do ponto de amostragem GU-06 seguindo esta tendência a jusante do reservatório.

Nas frações 2, redutível a óxidos de Fe e Mn, e 3, oxidável ligada a matéria orgânica, os maiores valores com maior enriquecimento foram obtidos a partir do ponto de amostragem GU-04 e segue esta tendência até a jusante do reservatório.

Para a fração 4, residual, a partir do ponto de amostragem GU-03 até jusante os valores tendem a aumentar, principalmente nos pontos GU-13 > GU-09 > GU05.

O cobre é um agente oxidante adicionado nos ambientes aquáticos na forma de sulfato de cobre $\left(\mathrm{CuSO}_{4}\right)$, um algicida comumente usados em represas de abastecimento de modo a minimizar o processo de eutrofização das águas (Richter et al., 2007).

De acordo com a CETESB (2014) a represa Guarapiranga é o manancial que mais recebeu aplicação de algicida ao longo dos anos. Estes dados corroboram com os valores encontrados neste trabalho, o comportamento e distribuição do cobre nas diferentes frações do reservatório ocorre do ponto GU-06 ao ponto de amostragem GU-14, principalmente, mas próximo a barragem, onde se localiza a área de captação de água pela SABESP. 


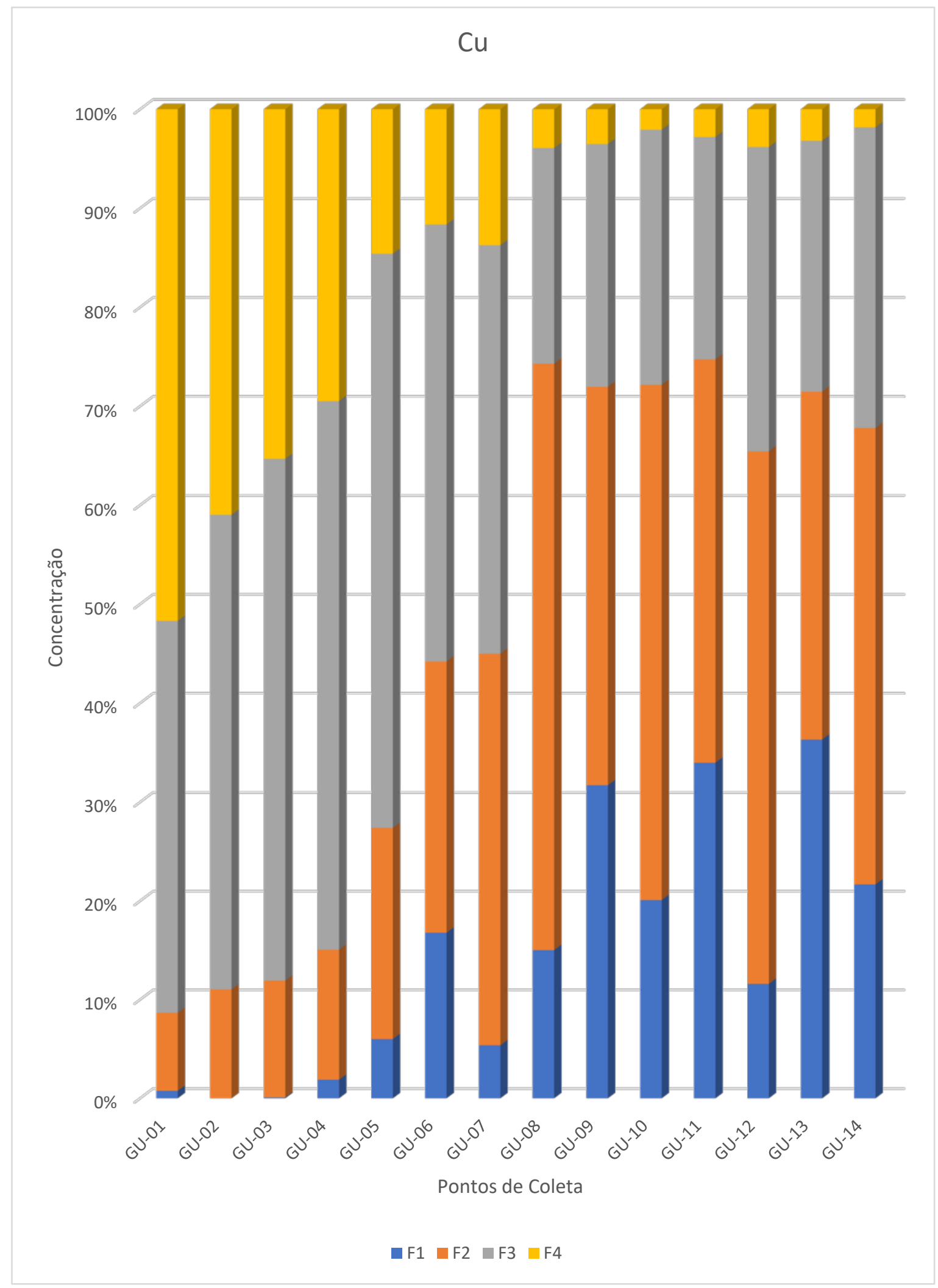

Figura 22: Distribuição percentual de Cu nas principais frações (F1, F2, F3 e F4) nos sedimentos superficiais amostrados no reservatório Guarapiranga. 


\subsubsection{Elemento Mn}

A Figura 23 apresenta os resultados da distribuição percentual de Mn nas frações (F1, F2, F3 e F4) analisadas nas amostras de sedimento superficiais.

Foi possível verificar que $\mathrm{Mn}$ apresentou uma distribuição significativa na fração trocável em todas as amostras avaliadas.

$\mathrm{Na}$ fração 1, trocável, os resultados foram maiores (próximos a 80\%), principalmente nos pontos de amostragem GU-13>GU-14>GU-10> GU-11 e GU-6.

O ponto de amostragem GU-03 apresentou maior enriquecimento nas frações 2, óxidos de Fe e Mn, e 3, oxidável ligada a matéria orgânica.

A fração 4, residual, nos pontos de amostragem GU-02 > GU-01 ocorreram as maiores concentrações, quando comparados aos demais pontos do reservatório.

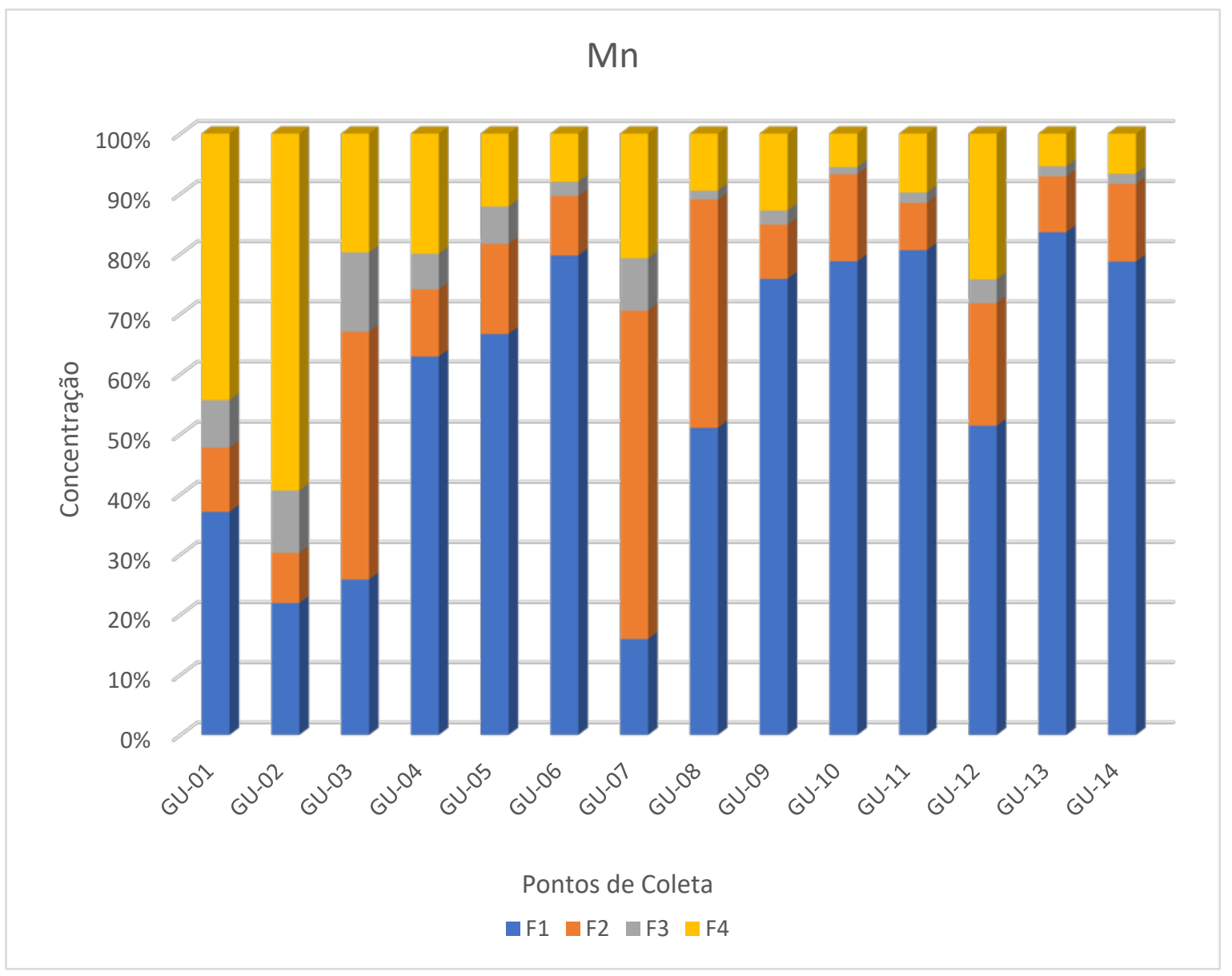

Figura 23: Distribuição de $M n$ nas principais frações (F1, F2, F3 e F4) nos sedimentos superficiais amostrados no reservatório Guarapiranga. 


\subsubsection{Elemento P}

A Figura 24 apresenta os resultados da distribuição percentual de $P$ nas principais frações do processo de extração sequencial.

Foi possível verificar que o $\mathrm{P}$ se encontra majoritariamente mais enriquecido na fase biodisponível.

Sua maior concentração na fração 1 , ácido solúvel ligada a carbonatos, ocorreu no ponto de amostragem GU-07. Já para a fração 2, redutível ligada a óxidos de Fe e Mn, a partir do ponto de amostragem GU-06 até a montante do reservatório, houve uma tendência no crescimento dos valores obtidos. A fração 3, oxidável ligada a matéria orgânica, evidenciou sua concentração nos pontos de amostragem GU-09 > GU-05 GU-13.

A fração 4 residual apresentou os maiores valores nos pontos de amostragem GU-05 > GU-06 > GU-11 > GU-09 > GU-12 > GU-03 > GU-04. Os demais pontos obtiveram resultados pouco expressivos. 


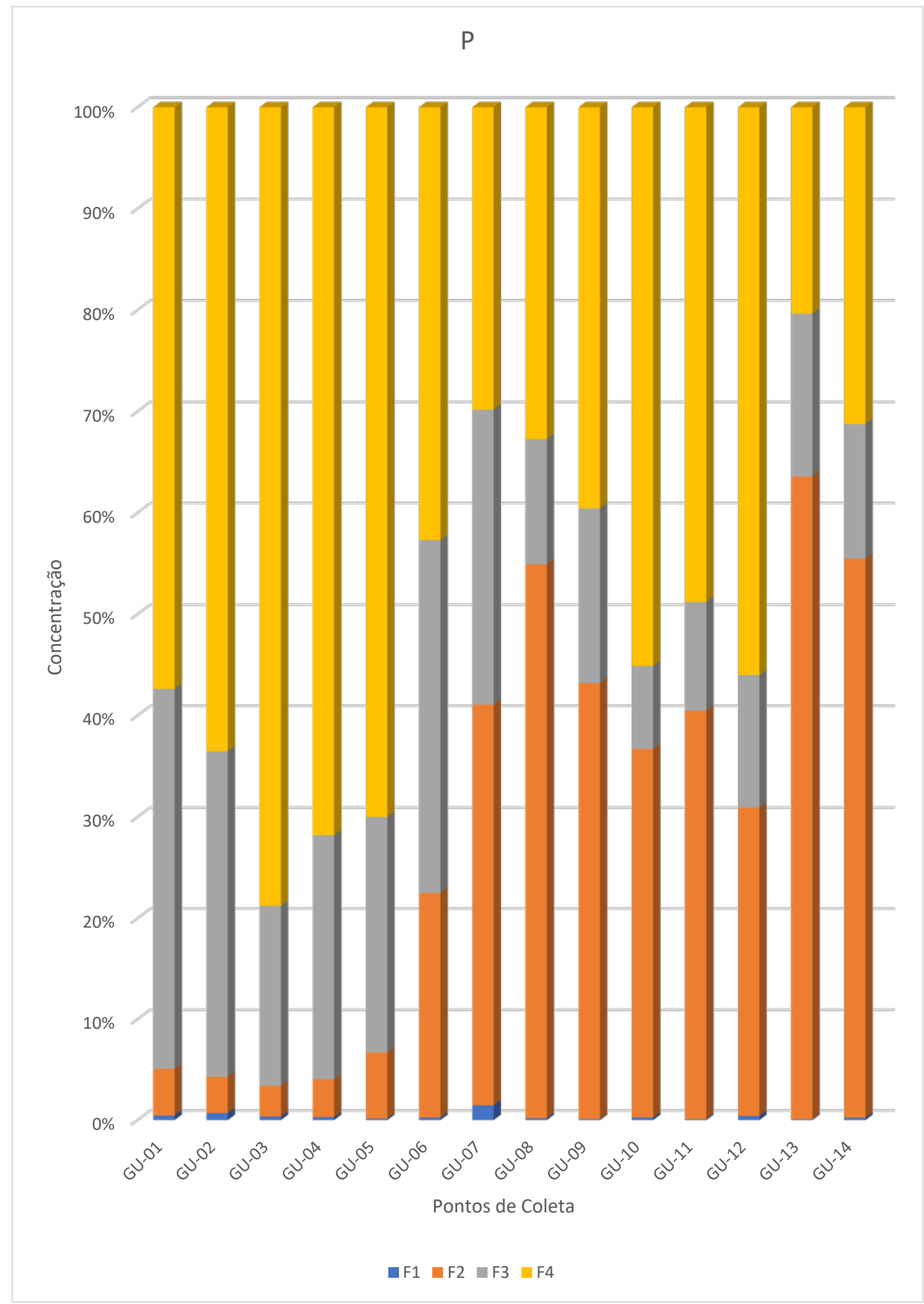

Figura 24: Distribuição percentual da concentração de $P$ nas principais frações ( $F 1$, F2, F3 e F4) nos sedimentos superficiais amostrados no reservatório Guarapiranga. 
O fósforo é um dos nutrientes mais abundantes na natureza, e sua disponibilidade no ambiente aquático tem aumentado devido ao uso de fertilizantes e ao aporte de esgotos urbanos e industriais (Figueiredo et al., 2007; Silva, 2016).

Uma vez que a maioria dos reservatórios se encontram em processo de eutrofização, o sedimento pode ser de fundamental importância na imobilização e liberação do fósforo na coluna d'água (Silva, 2016).

Devido ao aporte adicional de matéria orgânica proporcionado pelos esgotos urbanos e industriais, o reservatório Guarapiranga vem sofrendo acentuado processo de eutrofização e, em consequência, o comprometimento ao abastecimento público (Martinelli et al, 2002; Brooke et al., 2008).

A eutrofização é o crescimento excessivo de plantas aquáticas por meio de uma superfertilização, vários estudos indicam uma relação entre a concentração de fósforo e o crescimento algal, o que tem contribuído significativamente na qualidade da água, e interferindo nos usos desejáveis do reservatório (Brooke et al., 2008).

Segundo a literatura a maior proporção do fósforo nos sedimentos está associada a metais como $\mathrm{Al}, \mathrm{Fe}, \mathrm{Ca}$ e $\mathrm{Mn}$, tanto em condições redutoras quanto oxidantes (Kleeberg et al. 2012).

Particularmente com relação ao ferro, na forma $\mathrm{Fe}^{+3}$ compostos como o $\mathrm{Fe}(\mathrm{OH})_{3}$ adsorvem fortemente o fósforo, formando uma microzona oxidada sobre a superfície do sedimento, levando a grandes retenções de fósforo. Na sua forma reduzida, o $\mathrm{Fe}^{+2}$ torna-se solúvel e o fósforo anteriormente associado é liberado (Silva, 2016).

\subsection{Biodisponibilidade}

A biodisponibilidade pode ser entendida como a disponibilidade da concentração total ou parcial de um elemento químico para a ingestão, inalação ou assimilação por um organismo vivo, entretanto, a efetiva disponibilidade vai depender das condições ambientais como composição iônica da água, mudanças de pH, presença de matéria orgânica (Souza et al., 2015). 
Embora as concentrações obtidas para alguns metais indiquem uma provável contaminação do sedimento do reservatório Guarapiranga, este sedimento pode não apresentar toxicidade, pois para a disponibilidade destes elementos, outros fatores podem estar presentes nas fases complexadoras, como pH, reações de oxidação e matéria orgânica (Souza et al., 2015; Pompêo et al., 2013).

Com o aumento do $\mathrm{pH}$, a mobilidade dos metais é reduzida, uma vez que o mecanismo de adsorção é favorecido em altos valores de $\mathrm{pH}$, pois a superfície de cargas negativas é aumentada, o que favorece a atração eletrostática entre o sorvente e o metal. Entretanto, quando a faixa de pH está entre 4,0 e 6,0, a solubilidade de metais é menor devido a formação de complexos organo-minerais insolúveis (Souza, 2015).

Nos estudos realizados por Silva (2016), foi possível verificar que o pH da água do reservatório Guarapiranga no período de 2011 estava dentro do limite estabelecido pelo CONAMA 357/05, apresentando uma variação de $\mathrm{pH}$ 6,0 a 9,0 para os 14 pontos amostrados nos três níveis, superfície, meio e fundo.

Desta forma, fica evidenciado uma possível disponibilidade dos metais com relação ao pH em seu meio natural devido a faixa de pH verificada por Silva (2016).

Segundo Esteves (2011), o sedimento do reservatório Guarapiranga é orgânico devido ao teor de matéria orgânica ser superior a 10\% do seu peso seco. A matéria orgânica, tem efeito na especiação química dos íons metálicos, controlando assim a biodisponibilidade e toxicidade dos metais (Pompêo et al., 2013).

A biodisponibilidade dos metais decresce com a sequência de extração, dos mais disponíveis para os menos disponíveis, devido a força iônica dos reagentes utilizados (Sharamel et al., 2000).

O Ferro é um metal que faz parte da constituição geológica e, em quantidade adequada é essencial ao sistema bioquímico, no entanto, deve-se considerar que mesmo os metais essenciais, são tóxicos se os níveis de exposição e as concentrações forem suficientemente altos (CETESB, 2004). 
Com exceção dos pontos de amostragem GU-05, GU-06 e GU-08, todos os outros pontos apresentaram baixa biodisponibilidade do ferro (Figura 25).

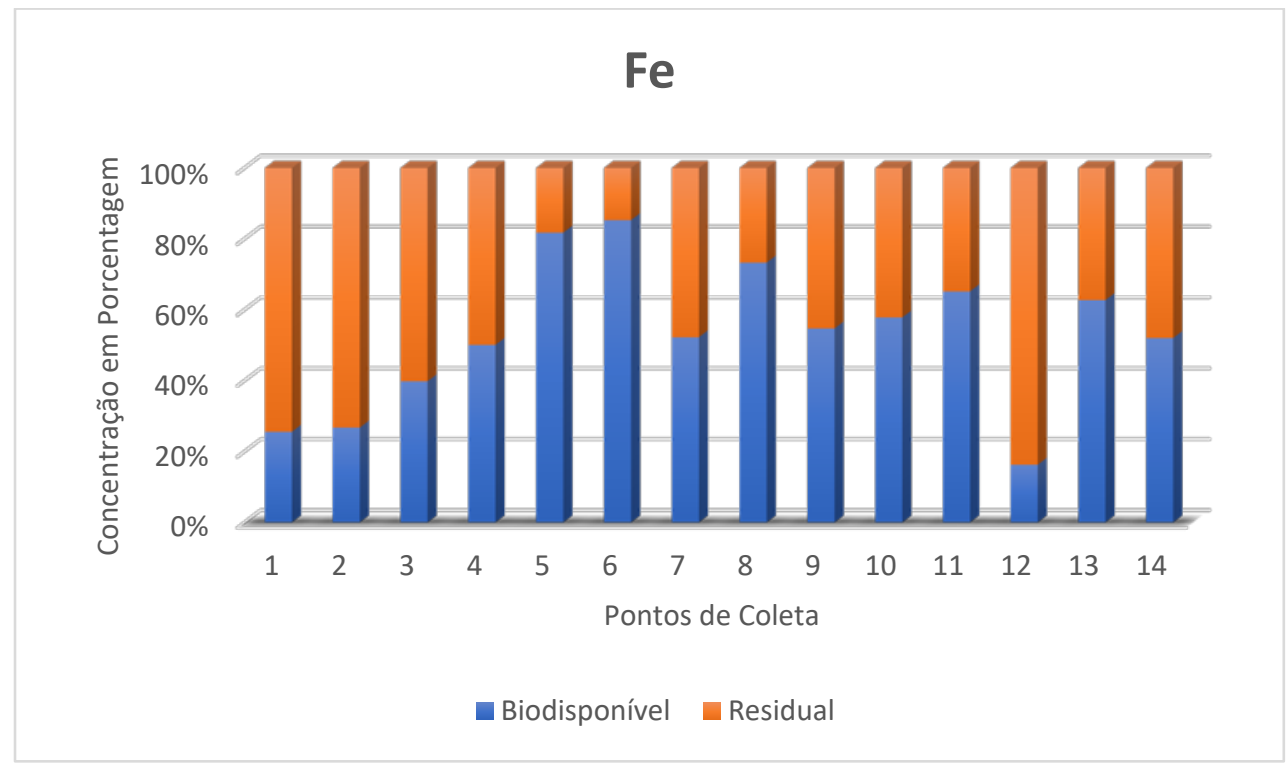

Figura 25. Concentração em Porcentagem das frações biodisponíveis e residuais obtidas nos pontos de coleta para o elemento Fe.

O alumínio é um metal que faz parte da constituição geoquímica do sedimento do reservatório Guarapiranga e esse fato é verificado na Figura 26, onde é possível verificar que, do total extraído, menos de 20\% está biodisponível, e que quase sua totalidade está presente na fase residual do processo extração sequencial.

A presença do Al na fase biodisponível é decorrente do lançamento de efluente industrial, esgoto doméstico, resíduos industriais, de mineração e de produtos utilizados na agricultura (CETESB, 2014).

Os valores de Al também podem estar relacionados ao sulfato de alumínio na represa (SABESP, 2008).

Embora existam várias fontes de Al para a represa, os valores encontrados neste trabalho sugerem que a biodisponibilidade deste metal para o ambiente não é expressiva. 


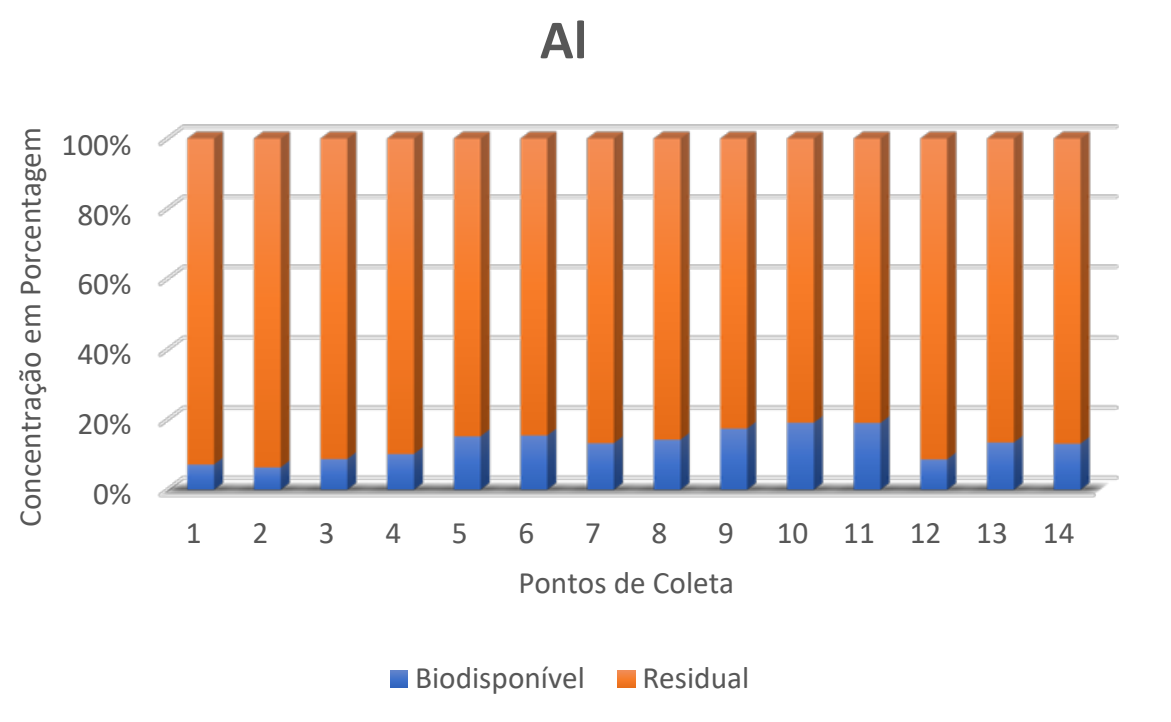

Figura 26. Concentração, em porcentagem, das frações biodisponíveis e residuais obtidas nos pontos de coleta para o elemento Al.

A Figura 27 apresenta uma possível biodisponibilidade de zinco para o ambiente. Este resultado sugere que parte da concentração do zinco presente no reservatório tenha sido introduzido pela ação antrópica, devido ao crescimento populacional no entorno da represa, ligado ao lançamento de esgoto não tratado em diferentes córregos do sistema Guarapiranga. Além desta via de entrada, o zinco pode estar associado às fontes veiculares (Silva, 2016).

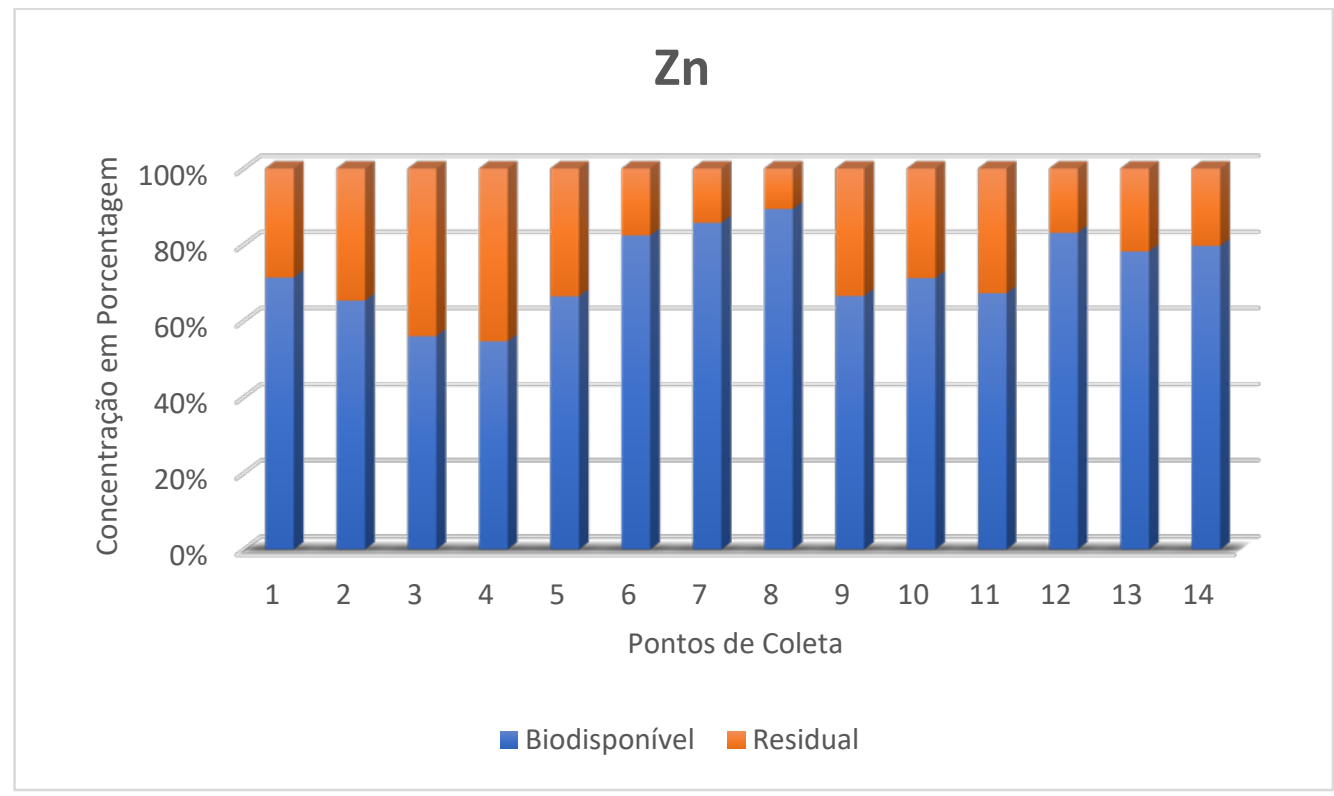

Figura 27. Concentração, em porcentagem, das frações biodisponíveis e residuais obtidas nos pontos de coleta para o elemento $\mathrm{Zn}$. 
Pode ser observado na Figura 28 uma tendência da biodisponibilidade do cromo seguindo de montante para jusante. Com exceção dos pontos de amostragem GU-07 e GU-08 que apresentam concentrações mais expressivas.

Os compostos de cromo podem ser encontrados nas natureza, e em ambientes não contaminados pela ação antrópica, o teor é aproximadamente de 1 $\mu \mathrm{g} . \mathrm{L}^{-1}$ na água e 0,1 $\mu \mathrm{g} \cdot \mathrm{m}^{-3}$ no ar (CETESB, 2014).

O cromo pode alcançar o reservatório por meio do lançamento de efluentes industriais. No sedimento, o cromo é dissolvido quando há reação redox, e esta reação pode ser lenta ou rápida, tudo vai depender da concentração de matéria orgânica e da presença de íons de sulfato de ferro em condições anaeróbias (Silva, 2016).

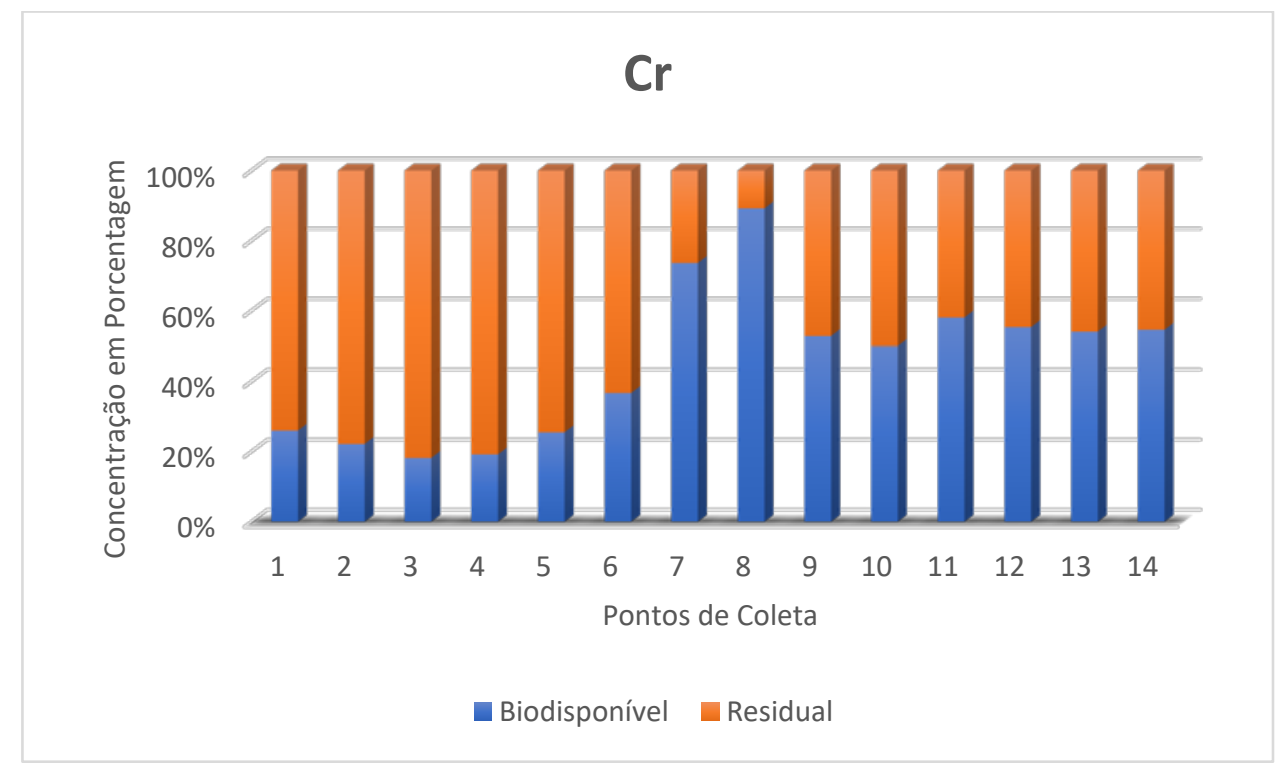

Figura 28. Concentração em Porcentagem das frações biodisponíveis e residuais obtidas nos pontos de coleta para o elemento $\mathrm{Cr}$. 
Conforme apresentado na Figura 29, os resultados mostram que o $\mathrm{Cu}$ apresenta maior biodisponibilidade a partir do ponto de amostragem GU-05 e segue esta tendência até montante. A elevada concentração de $\mathrm{Cu}$ na fração matéria orgânica, principalmente nos pontos mais próximos da capitação, está associada com o uso de sulfato de cobre como algicida, aplicada no reservatorio Guarapiranga, desde a primeira floração de algas, pela Companhia Estadual de Saneamento Basico do Estado de São Paulo - SABESP, responsável pela captação, tratamento fornecimento de água no Estado de São Paulo, Sabesp, em 1990 (Fontana et al, 2014).

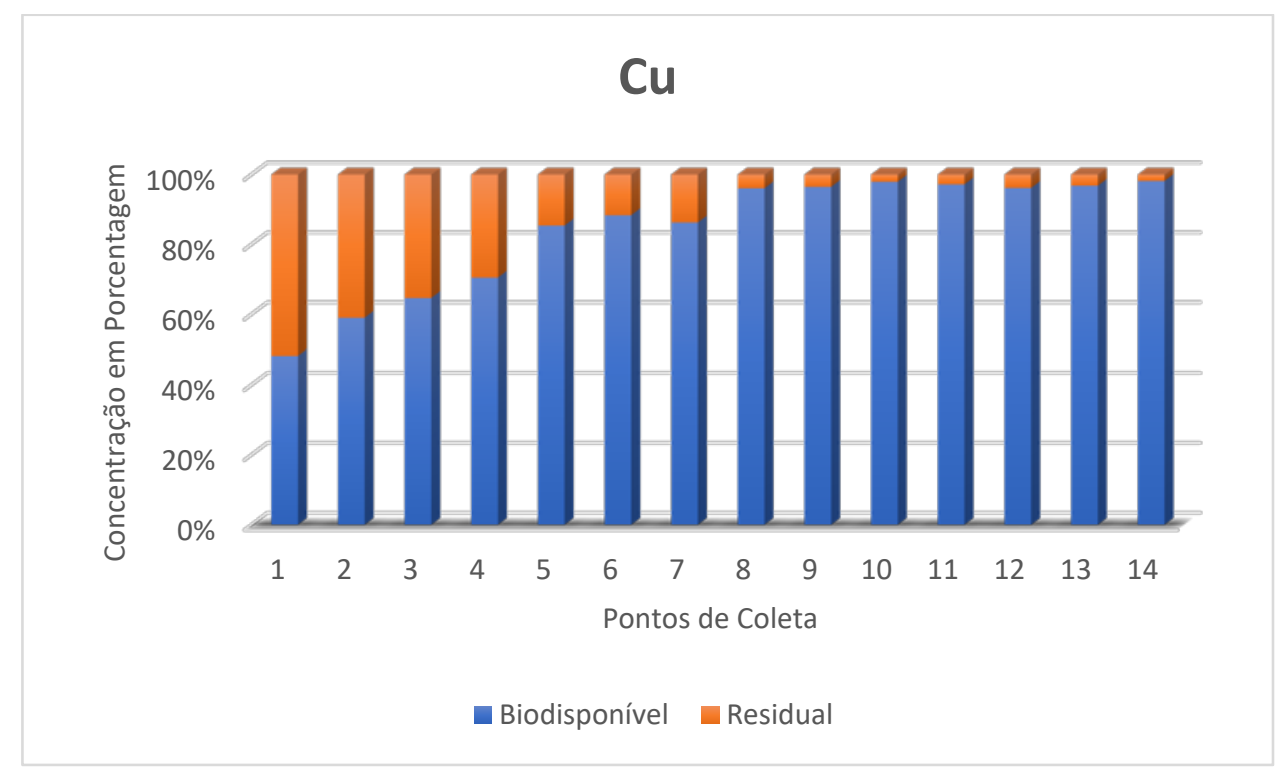

Figura 29. Concentração em Porcentagem das frações biodisponíveis e residuais obtidas nos pontos de coleta para o elemento $\mathrm{Cu}$. 
Manganês apresentou elevada biodisponibilidade nos pontos amostrados seguindo uma tendência até a barragem (Figura 30).

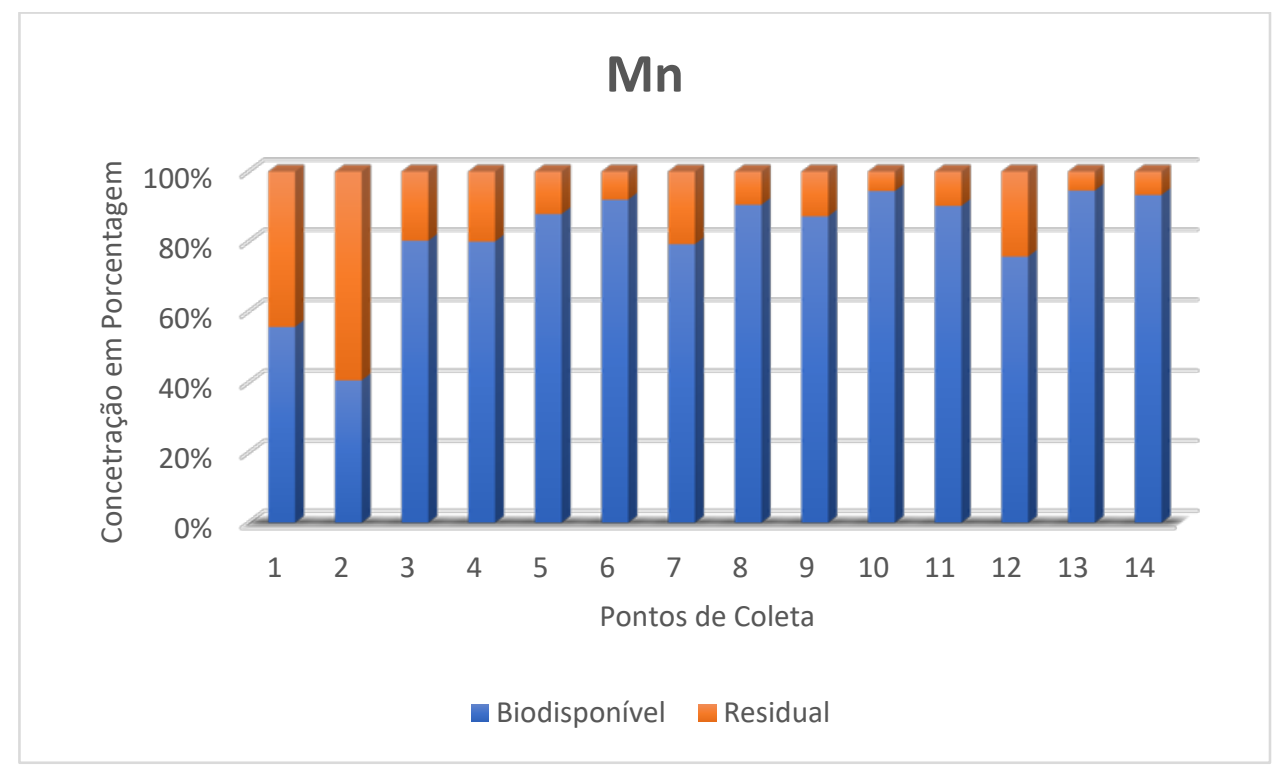

Figura 30. Concentração em Porcentagem das frações biodisponíveis e residuais obtidas nos pontos de coleta para o elemento Mn.

A biodisponibilidade do fósforo (Figura 31) evidencia atividades antrópicas na região do reservatório Guarapiranga e indica que o reservatório se encontra eutrofizado, pois o elemento fósforo pode manter diferentes concentrações solúveis na água e adsorvidas no sedimento, a qual pode ocorrer a dessorção com qualquer alteração ambiental. Este fato é evidenciado também por Fontana e colaboradores (2014). 


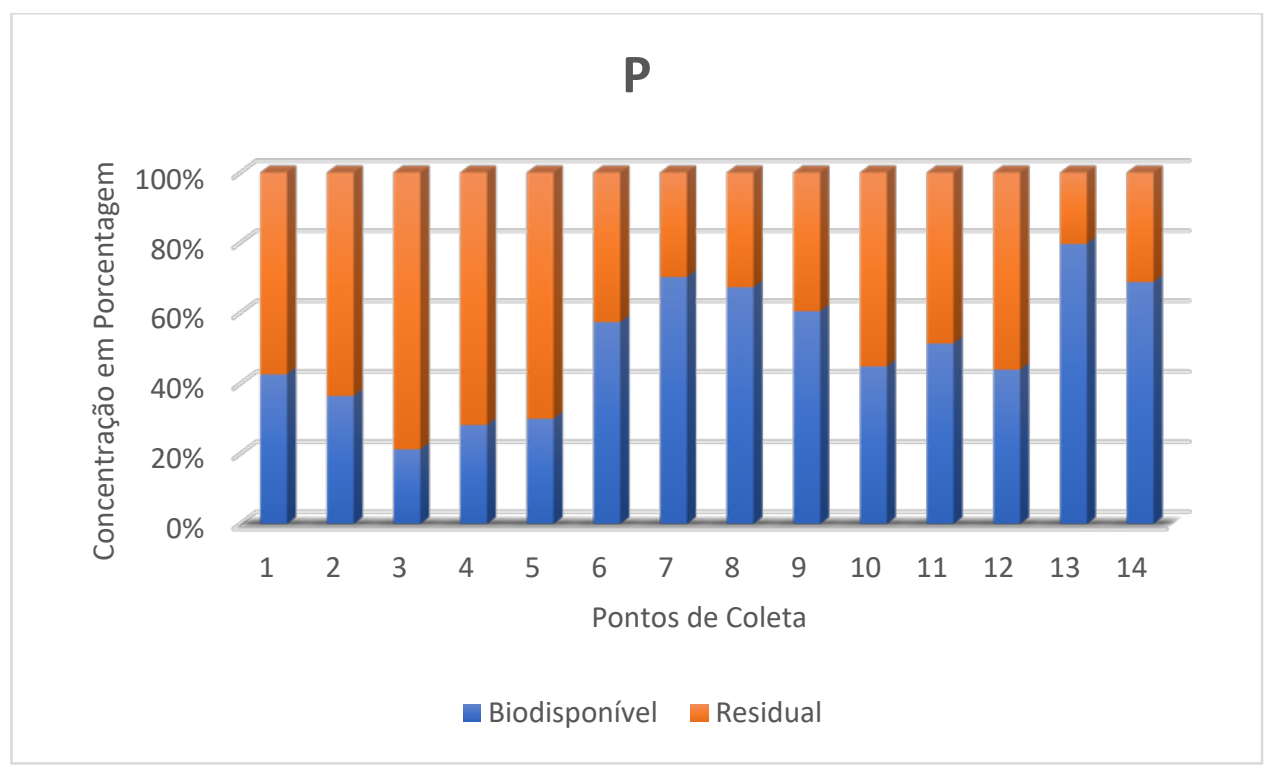

Figura 31. Concentração em Porcentagem das frações biodisponíveis e residuais obtidas nos pontos de coleta para o elemento $P$.

Bevilacqua (1996) evidenciou que um metal pode apresentar a mesma concentração em diferentes sedimentos e sua toxicidade se exibida em apenas um deles, o que indica que a toxicidade é dependente do fator de biodisponibilidade do contaminante.

Dessa forma, ainda que o sedimento tenha sido contaminado em algum período, é possível que a biodisponibilidade ocorra apenas em uma fração do conteúdo metálico total, fazendo com que a toxicidade dos sedimentos varie não somente em função da concentração total, mas também pela forma como estão fixados ao sedimento. Portanto, o metal nele retido pode não ser considerado um contaminante, já que apenas a forma química em que se encontra é que pode caracterizá-lo como impactante ou não. 


\subsection{Concentração de Metais no Sedimento segundo os Valores Guia de Qualidade de Sedimento - VGQS}

As Figuras 32 a 34 apresentam uma comparação das concentrações dos metais $\mathrm{Cu}, \mathrm{Cr}$ e Zn no reservatório com os Valores Guia de Qualidade de Sedimento (TEL e PEL). Para elaboração dos gráficos, foram utilizadas as médias das tréplicas de concentração dos metais, por ponto de amostragem.

O metal cobre apresentou maiores concentrações no sedimento nos pontos GU-13>GU-14>GU-09>GU-10>GU-11>GU-08>GU-12>GU-05>GU-06>GU-07.

A tendência demonstra grande incremento das concentrações de Cu no sentido barragem (Figura 32). A partir do ponto GU-05, todos os pontos de coleta apresentaram concentrações de cobre acima dos valores de PEL. Vale ressaltar que valores acima de PEL apresentam provável toxicidade ao organismo.

Os valores encontrados neste trabalho corroboram com os resultados obtidos por Zagatto \& Aragão (1995), onde os autores apontam níveis de contaminação acima de PEL na região central e próximo à barragem. As regiões do reservatório apontadas pelos autores correspondem aos sítios amostrados neste trabalho, que são: GU-05, GU-06 e GU-07 região central e aos GU-08 ao GU14 região próximo à barragem.

Araújo (1998), Padial (2008), Pompêo e colaboradores (2013) e Lage (2013) também encontraram valores acima de PEL nas regiões central e barragem, indicando enriquecimento de cobre na represa sentido barragem.

Em estudo toxicológico, Araújo (1998) não observou efeito agudo para Hyalella sp., entretanto, a comunidade bentônica foi considerada ruim e foi observada a presença de organismos resistentes à poluição por esgotos domésticos. Todos estes resultados indicam que há muito tempo o reservatório Guarapiranga apresenta elevada contaminação por cobre. 
Distribuição $\mathrm{Cu}$

Sedimento Represa Guarapiranga

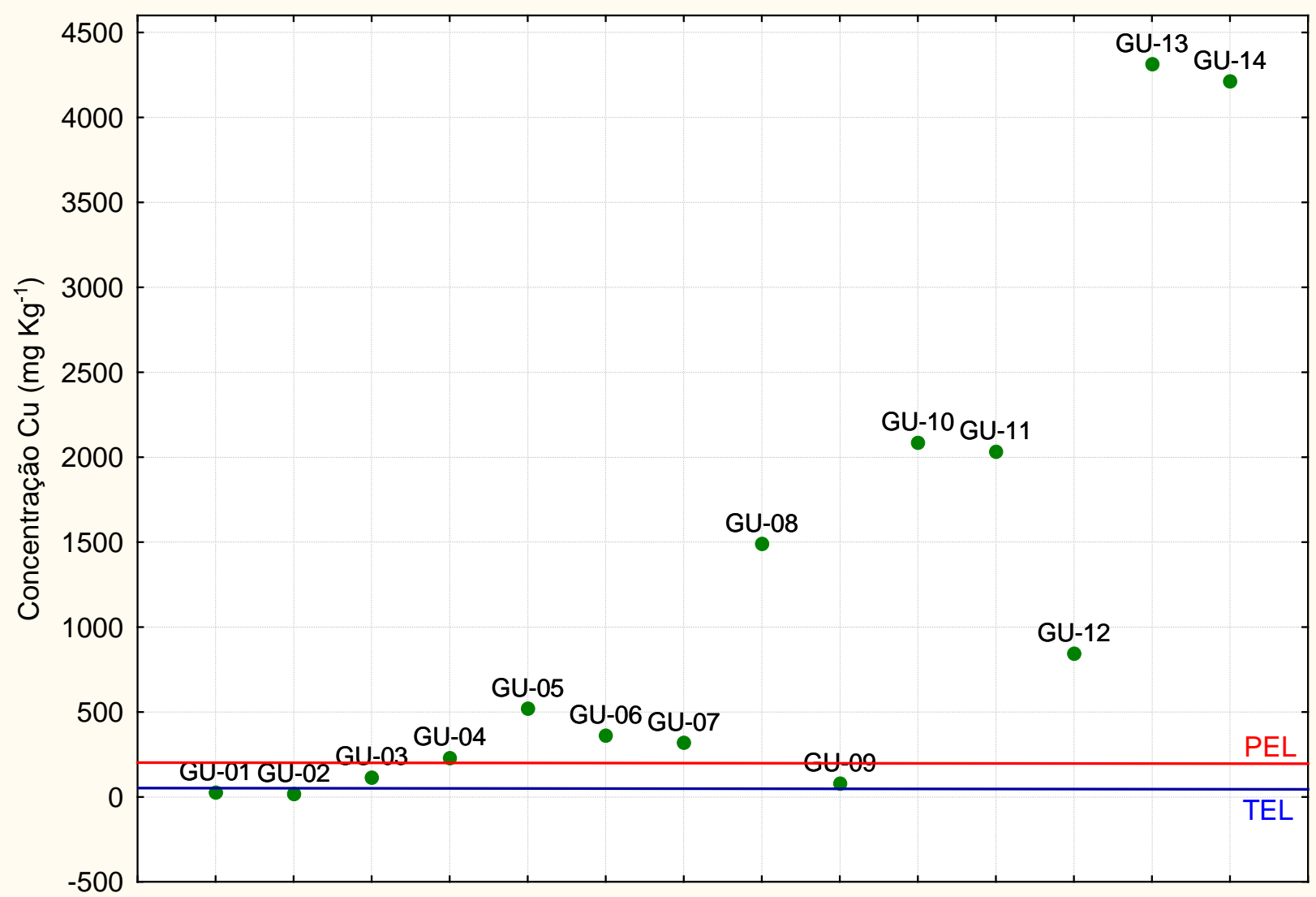

Figura 32: Concentração de Cu no sedimento dos 14 pontos de amostragem no Reservatório Guarapiranga e Valores - Guia de Qualidade de Sedimento (TEL e PEL).

Os relatórios da CETESB (2014) têm apresentado qualidade péssima para o sedimento da represa Guarapiranga, onde as concentrações de Cu encontramse acima dos valores de PEL. Estes valores corroboram com os dados encontrados neste trabalho. 
O metal cromo apresentou maiores concentrações no ponto GU-03, entretanto, entre os pontos amostrados, nenhum apresentou concentrações acima de PEL. Os pontos de amostragem GU-01, GU-02, GU-03, GU-04, GU-05, GU-06 GU-13 e GU-14, apresentaram concentrações acima de TEL, ficando na fração entre TEL e PEL o que pode representar toxicidade incerta para o ambiente (Figura 33).

Os sítios amostrados de GU-07 a GU-12 apresentaram valores abaixo de TEL, indicando toxicidade improvável e sugerem que nestes sítios, o cromo não está biodisponível para assimilação pelos organismos.

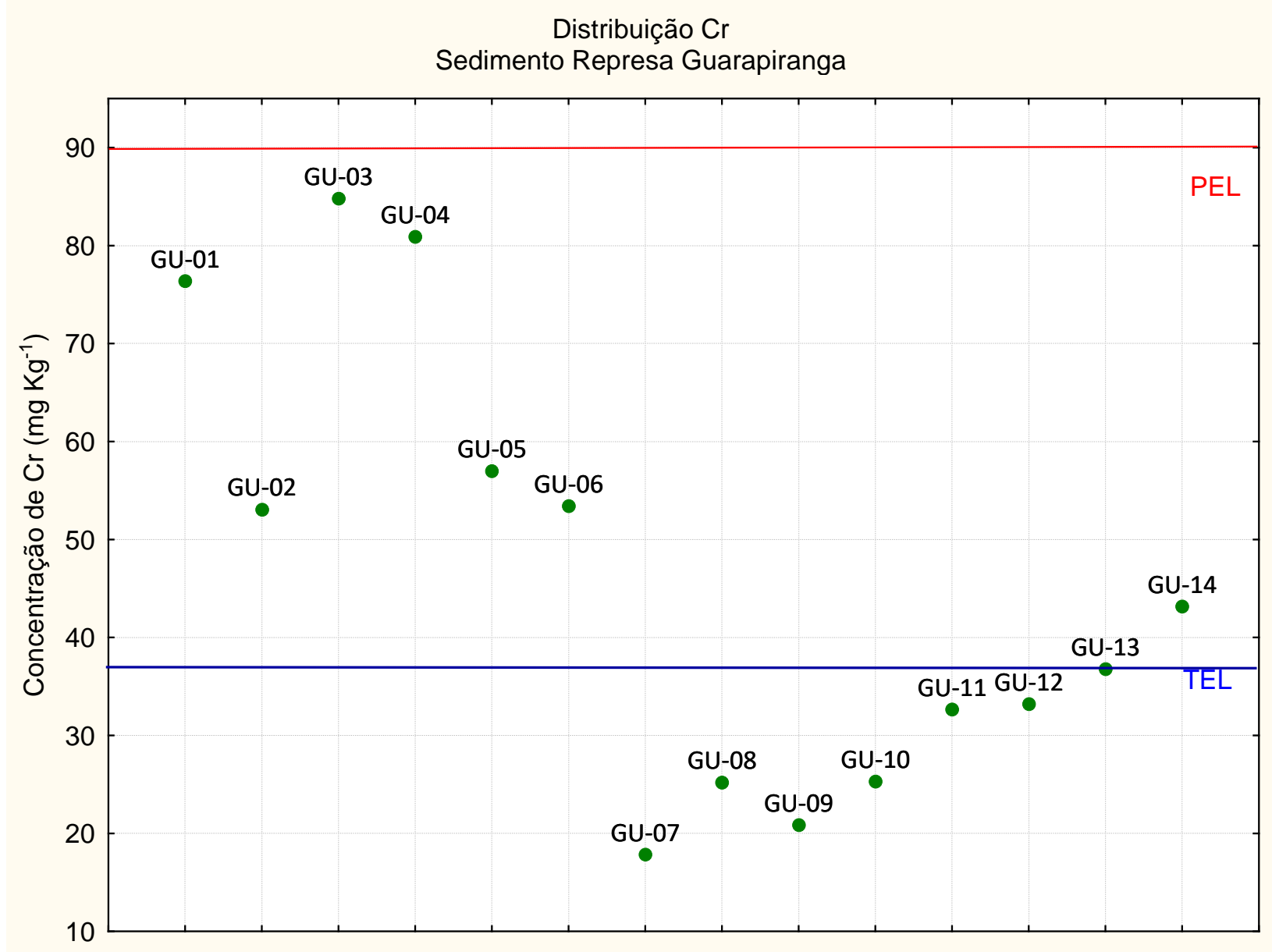

Figura 33: Concentração de $\mathrm{Cr}$ no sedimento dos 14 pontos de amostragem no Reservatório Guarapiranga e Valores - Guia de Qualidade de Sedimento (TEL e PEL). 
Padial (2008) em seus estudos obteve em alguns sítios amostrados cromo na zona transitória entre TEL e PEL, principalmente nos pontos que se localizam na região mais central da represa e segue em direção à barragem. Estes resultados corroboram com os encontrados por Lage (2013) e por este estudo.

As concentrações de zinco foram encontradas em maiores valores no ponto GU-08 e GU-12. Nenhum ponto apresentou concentrações acima de PEL. Não foi observada tendência linear significativa para este elemento (Figura 34).

Os pontos amostrados GU-02, GU-05, GU-06, GU-09, GU-10 e GU-11 apesentaram valores abaixo de TEL, indicando improvável toxicidade destes sítios amostrados para zinco.

De acordo com Lage (2013), não houve tendência de aumento de zinco sentido barragem, o mesmo ocorreu com Padial (2008), o que corroboram para os resultados obtidos neste estudo. 
Distribuição Zn

Sedimento Represa Guarapiranga

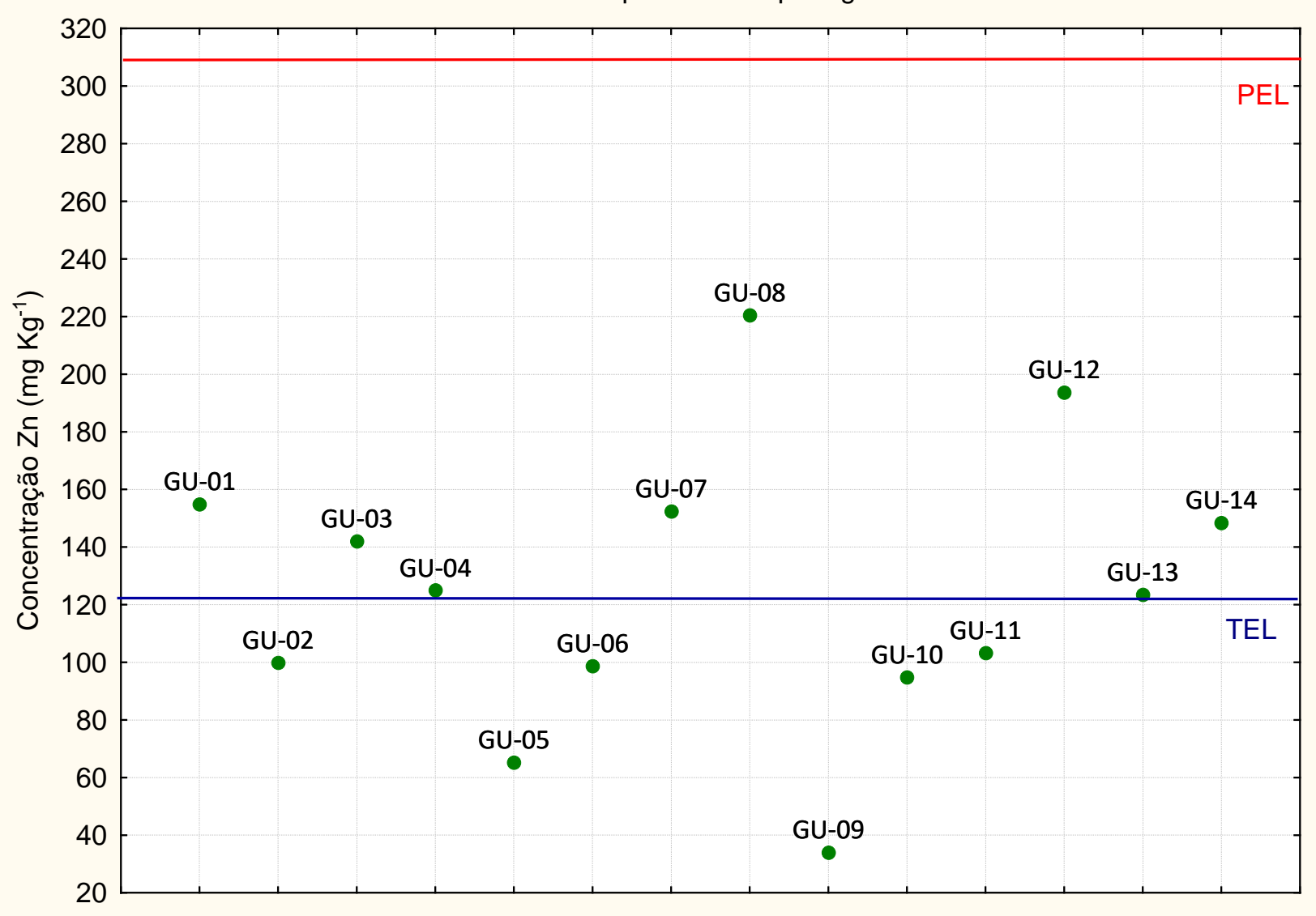

Figura 34: Concentração de $\mathrm{Zn}$ no sedimento dos 14 pontos de amostragem no Reservatório Guarapiranga e Valores - Guia de Qualidade de Sedimento (TEL e PEL).

No ano de 2014, em seu Relatório de Qualidade das Águas Interiores no Estado de São Paulo, a CETESB apresentou os resultados de TEL e PEL para cobre, cromo e zinco. Os resultados apresentados indicam cobre bem acima de PEL, apresentando $916 \mathrm{mg} / \mathrm{kg}$, cromo 61,5 mg/kg ficando na faixa transitória entre TEL e PEL, e zinco $99.4 \mathrm{mg} / \mathrm{kg}$ estando abaixo de TEL.

Os resultados exibidos pela CETESB (2014) corroboram com os encontrados por Padial (2008), Lage (2013) e por este estudo.

Os valores das concentrações dos metais analisados estão na maioria dos pontos entre TEL e PEL, o que representa contaminação da represa e toxicidade incerta para os organismos que estão em contato com altas concentrações de metais. 


\subsection{Mobilidade dos metais e do fósforo}

A mobilidade dos metais no sedimento não depende somente de sua concentração total e, sim, de processos como adsorção e dessorção; precipitação/dissolução (Acosta et al., 2011), que podem facilitar sua mobilidade para o ambiente devido a constantes alterações nos parâmetros físicos químicos como o pH (Fontana, 2013). Deste modo, a mobilidade dos metais decresce a cada fração da extração sequencial devido a força de ligação do metal, indicando assim, que a fração F1 é a que representa a mobilidade dos metais para o ambiente (Pereira et al., 2007; Ashraf et al., 2012; Coringa, 2014).

Estas capacidades de trânsito dos metais entre os compartimentos ambientais são tratadas na literatura como fatores de mobilidade ou fatores de contaminação (Pereira et al., 2007; Coringa, 2014). O cálculo desse fator é importante, pois permite avaliar o impacto que esses metais traços podem causar no ambiente.

Foi aplicado o fator de mobilidade (FM) aos dados obtidos em cada amostra (Fernandes, 1997; Pereira et al., 2007).

Por meio da Equação 1, foi possível verificar o fator de mobilidade individual $\left(M_{f}^{i}\right)$ e o fator de mobilidade global $\left(\mathrm{M}_{f}\right)$ foi obtido a partir da somatória do FMI, expresso na Equação 2 (Pereira et al., 2007). Os fatores de mobilidade calculado para cada elemento avaliado neste estudo estão apresentados na Tabela 9.

$$
M_{f}^{i}=\frac{F 1+F 2+F 3}{F 4}
$$

Equação 1

Onde:

F1 - fração trocável

F2 - fração óxido de Fe e Mn

F3 - fração matéria orgânica

F4 - fração residual 


$$
M_{f}=\sum M_{f}^{i}
$$

Equação 2

Tabela 9. Fator de mobilidade individual $\left(M_{f}^{i}\right)$ e fator de mobilidade global $\left(M_{f}\right)$

\begin{tabular}{|c|c|c|c|c|c|c|c|c|}
\hline \multirow{2}{*}{ Identificação } & \multicolumn{8}{|c|}{ Fator de mobilidade } \\
\hline & & & & Individ & & & & Global \\
\hline Pontos de Coleta & $\mathrm{Fe}$ & Al & $\mathrm{Zn}$ & $\mathrm{Cr}$ & $\mathrm{Cu}$ & $\mathrm{Mn}$ & $P$ & $\begin{array}{c}M_{\mathrm{f}}= \\
\sum \mathrm{M}_{\mathrm{f}}^{\mathrm{i}}\end{array}$ \\
\hline GU-01 & 0,34 & 0,08 & 2,49 & 0,35 & 0,93 & 1,26 & 0,74 & 6,20 \\
\hline GU-02 & 0,37 & 0,07 & 1,88 & 0,29 & 1,44 & 0,68 & 0,57 & 5,30 \\
\hline GU-03 & 0,66 & 0,10 & 1,27 & 0,22 & 1,83 & 4,06 & 0,27 & 8,42 \\
\hline GU-04 & 1,00 & 0,11 & 1,20 & 0,24 & 2,39 & 4,01 & 0,39 & 9,35 \\
\hline GU-05 & 4,48 & 0,18 & 1,98 & 0,34 & 5,85 & 7,24 & 0,43 & 20,50 \\
\hline GU-06 & 5,79 & 0,18 & 4,70 & 0,58 & 7,59 & 11,48 & 1,34 & 31,66 \\
\hline GU-07 & 1,09 & 0,15 & 6,03 & 2,79 & 6,28 & 3,82 & 2,35 & 22,52 \\
\hline GU-08 & 2,74 & 0,17 & 8,42 & 8,26 & 24,48 & 9,55 & 2,05 & 55,67 \\
\hline GU-09 & 1,21 & 0,21 & 1,99 & 1,12 & 27,45 & 6,82 & 1,53 & 40,32 \\
\hline GU-10 & 1,37 & 0,24 & 2,48 & 1,00 & 47,23 & 16,97 & 0,81 & 70,11 \\
\hline GU-11 & 1,87 & 0,24 & 2,05 & 1,39 & 34,68 & 9,21 & 1,05 & 50,48 \\
\hline GU-12 & 0,19 & 0,10 & 4,93 & 1,24 & 25,16 & 3,12 & 0,79 & 35,53 \\
\hline GU-13 & 1,68 & 0,16 & 3,59 & 1,18 & 30,37 & 17,45 & 3,91 & 58,34 \\
\hline GU-14 & 1,08 & 0,15 & 3,93 & 1,20 & 53,69 & 13,96 & 2,20 & 76,21 \\
\hline
\end{tabular}




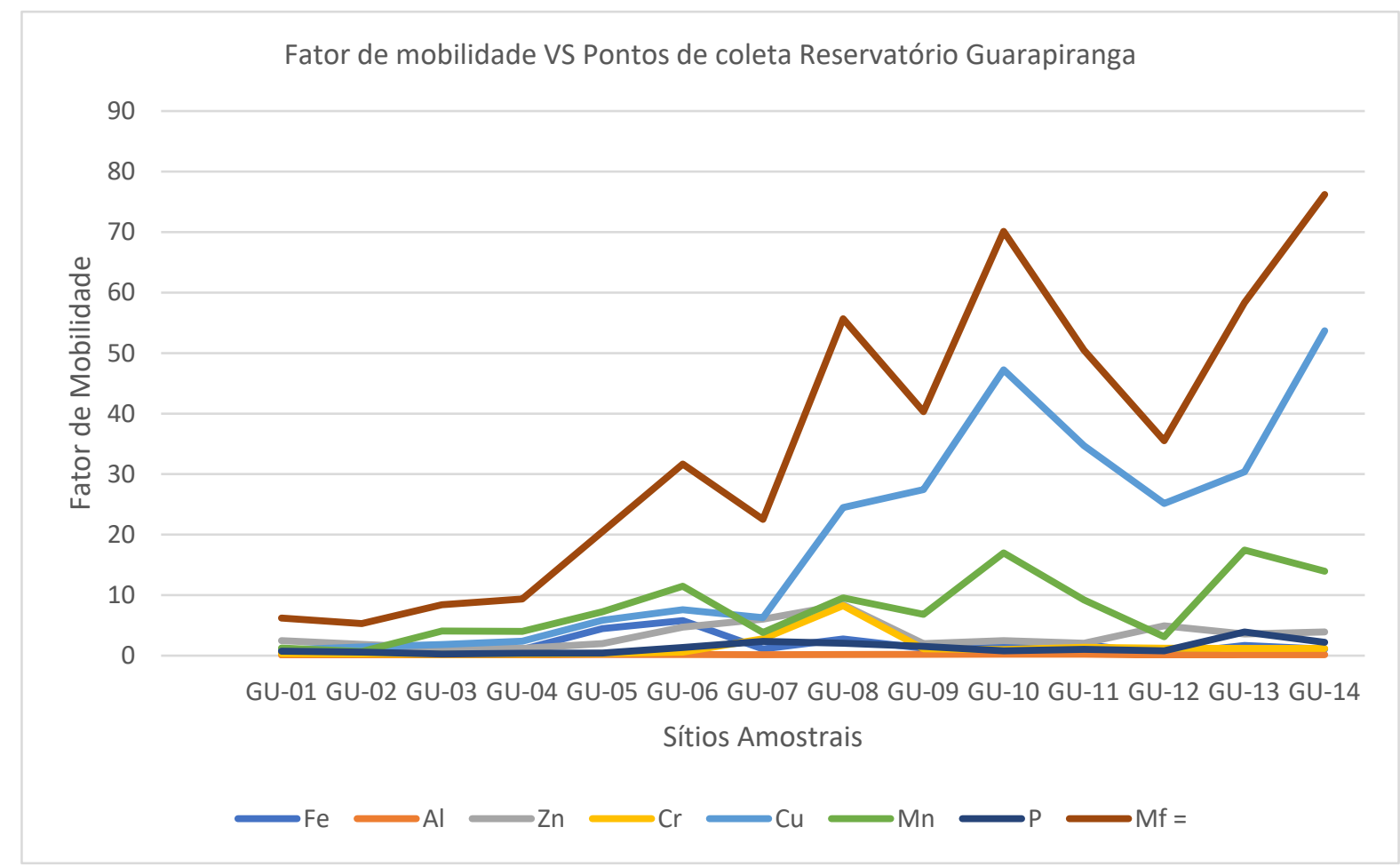

Figura 35. Representação gráfica do fator de mobilidade individual $\left(M_{f}^{i}\right)$ para os elementos $\mathrm{Fe}, \mathrm{Al}, \mathrm{Zn}, \mathrm{Cr}, \mathrm{Cu}, \mathrm{Mn}$ e $\mathrm{P}$ e fator de mobilidade global $\left(M_{f}\right)$ no reservatório.

Os fatores de mobilidade global calculados para o reservatório, considerando todos os sítios do reservatório do Guarapiranga confirmam um enriquecimento de metais nas frações mais disponíveis e ao longo do fluxo da bacia, ou seja, estes índices aumentam no sentido sítio GU-01 < GU-14 (Figura 35).

Os sítios mais impactados para cobre são as estações GU-10 e GU-14, as quais apresentam os maiores índices de mobilidade 70,11 e 76,21, respectivamente. O maior fator de mobilidade individual calculado foi de 53,69 para o $\mathrm{Cu}$, no ponto de amostragem GU-14. Manganês também apresentou fator de mobilidade individual elevado, sendo os sítios mais expressivos para este elemento o GU-10 e o GU-13. 


\section{CONCLUSÃO}

Por meio deste estudo, foi possível identificar que o reservatório Guarapiranga apresenta problemas decorrente principalmente da ocupação do entorno.

A extração sequencial seletiva permitiu avaliar a distribuição dos metais Fe, $\mathrm{Al}, \mathrm{Zn}, \mathrm{Cr}, \mathrm{Cu}, \mathrm{Mn}$ e do Fósforo de acordo com as frações geoquímicas associadas principalmente às fases biodisponível e residual, procurando dar subsídios ao estudo das interações, redistribuições e destino desses metais nos sedimentos aquáticos.

Por meio desta técnica foi possível avaliar a distribuição e a mobilidade dos metais potencialmente tóxicos em função das condições ambientais do meio aquático.

A abordagem espaço-temporal aplicada neste estudo foi adequada para constatar a contaminação do reservatório proveniente da progressiva ocupação do solo.

Os estudos de fracionamento indicaram que os metais foram encontrados nas frações mobilizáveis do sedimento.

Os maiores teores dos metais no sedimento encontram-se nas frações geoquímicas menos estáveis (na forma trocável, ligados a óxidos de ferro e à matéria orgânica).

A partir dos resultados obtidos infere-se que o reservatório do Guarapiranga apresenta dois compartimentos distintos, e um de transição. O trecho mais degradado vai do ponto 07 a 14 que sofre os impactos da ocupação do seu entorno e um mais preservado que vai do ponto 01 a 03, sem tanta influência de ocupação urbana no seu entorno. Entretanto, os pontos de 04 a 06 podem ser inseridos no trecho de transição, onde as concentrações dos elementos estudados são flutuantes.

Os VGQS aplicados classificam alguns sítios como impactados por cobre, cromo e zinco, estas faixas de concentração, principalmente a encontrada para cobre indicam que há grande probabilidade de efeitos tóxicos sobre os organismos. 
O fator de mobilidade aplicado mostra que a distribuição espacial do grau de mobilidade global segue tendência de montante à jusante, sendo que a região à jusante, próxima a barragem é uma área de intensa intervenção antrópica.

O fator de mobilidade individual sugere uma menor mobilidade para Fe e Al e uma maior mobilidade para $\mathrm{Cu}$ e $\mathrm{Mn}$ respectivamente, influenciando diretamente na disponibilidade destes elementos.

A qualidade química atual do sedimento do reservatório apresenta características de contaminação em decorrência da alta concentração de $\mathrm{Cu}, \mathrm{Mn}$, Zn e Cr. 


\section{REFERÊNCIAS BIBLIOGRÁFICAS}

ACOSTA, J. A.; JANSEN, B.; KALBETZ, K.; FAZ, A.; MARTÍNEZ-MARTÍNEZ, S. Salinity increases mobility of heavy metals in soils. Chemosphere, v. 85, p. 13181324, 2011.

ANA - Agência Nacional de Águas. Atlas Brasil - Abastecimento urbano de Água. Disponível em: <http://atlas.ana.gov.br/Atlas/forms/analise/RegiaoMetropolitana.aspx?rme=24> Acessado em 05 de junho de 2016.

ANDRADE, M. R. M. DE, SALIM, A., ROSSINI-PENTEADO, D., COSTA, J. A. DA, SOUZA, A. A. DE, SAAD, A. R.; OLIVEIRA, M. S. Mapeamento de uso da terra para avaliação da qualidade das águas do reservatório Guarapiranga. Geociências. V.34, n. 2, p. 258 - 274, 2015.

ARAUJO, R.P.A. Avaliação da toxicidade de sedimentos ao anfípodo de água doce Hyalella meinerti Stebbing, 1899 (Crustacea, Amphipoda). 1998. 184f. Dissertação (Mestrado) - Universidade de São Paulo, São Paulo, 1998.

ARRUDA, R. O.M.; DALMAS, F.B.; MILITÃO, J.C.; GARCIA, A.P. Análise geoambiental aplicada ao estudo da relação entre qualidade da água e ocupação das margens da represa Guarapiranga (São Paulo/SP), entre 2004 e 2014. Geociências. V. 15, n. 1, p. 77-93, 2016.

ASHRAF, M A, .MAAH M. J. \& YUSOFF, I. Speciation of heavy metals in the sediments of former tin mining catchment. Iranian Journal of Science \& Technology. A2:163-180. 2012.

BACON, J.R.; HEWITT, I.J.; COOPER, P. Reproducibility of the BCR sequential extraction procedure in a long-term study of the association of heavy metals with soil components in an upland catchment in Scotland. Science of the Total Environment, Amsterdam, v. 337, p. 191-205, 2005.

BEVILACQUA J.E. Estudos sobre a Caracterização e Estabilidade de Amostras de Sedimentos do Rio Tietê, SP. 1996. 171f. Tese (Doutorado) - Universidade de São Paulo, São Paulo. 1996.

BRASIL. Conselho Nacional do Meio Ambiente (CONAMA). Resolução n. 357, D.O.U. de 18/03/2005. 2005. Disponível em < http://www.mma.gov.br/port/conama/res/res05/res35705.pdf> Acessado em 10 de janeiro de 2017.

BRASIL. Conselho Nacional do Meio Ambiente (CONAMA). Resolução n. 454, D.O.U. de 08/1/2012. 2012. Disponível em <http://www.mma.gov.br/port/conama/legiabre.cfm?codlegi=693> Acessado em 10 de janeiro de 2017. 
BROOKE, D., RIBEIRO, D., RODRIGUES, L., CAMPOS, M. \& MENDES, R. Algas e seus impactos em sistemas de tratamento de água para abastecimento: Estudo de caso sistema gurapiranga. 2008. Disponível em: < http://www.brookepeig.com/downloads/Algas.pdf> Acessado em 15 de julho de 2017.

CCME, Canadian Council of Ministers of the Environment. 1999. Canadian Sediment Quality Guidelines for the Protection of Aquatic Life. Disponível em <http://ceqg-rcqe.ccme.ca/download/en/226> Acessado em 10 de janeiro de 2017.

CETESB \& ANA. 2011. Guia Nacional de Coleta e Preservação de Amostras Água, Sedimento, Comunidades Aquáticas. Brasília, 2Edição: s.n., 2011. Disponível em $<$ http://arquivos.ana.gov.br/institucional/sge/CEDOC/Catalogo/2012/GuiaNacional DeColeta.pdf> Acessado em 05 de janeiro de 2016.

CETESB. Companhia de Tecnologia de Saneamento Ambiental. Relatório de qualidade de águas interiores do Estado de São Paulo, São Paulo. 2016. Disponível em: < http://cetesb.sp.gov.br/aguas-interiores/wpcontent/uploads/sites/12/2013/11/Cetesb_QualidadeAguasInteriores_2017_0206_VF.pdf> Acesso em 02 Junho 2017.

CETESB. Companhia de Tecnologia de Saneamento Ambiental. Qualidade das águas superficiais no Estado de São Paulo. Parte I Águas Doces, São Paulo. 2015. Disponível em <http://aguasinteriores.cetesb.sp.gov.br/wpcontent/uploads/sites/32/2013/11/Cetesb_QualidadeAguasSuperficiais2015_Parte I_25-07.pdf> Acessado em 10 de janeiro de 2017.

CORINGA, J. E. S., PEZZA, L., CORINGA, E. A. O. \& WEBER, O. L. S. Distribuição geoquímica e biodisponibilidade de metais traço em sedimentos no Rio Bento Gomes, Poconé - MT, Brasil. Acta Amazonica. v46:161-174. 2016.

CORINGA, J.E.S. Fracionamento Geoquímico de Metais em Sedimentos e Avaliação da Qualidade da Água do Rio Bento Gomes, Pantanal de Poconé, Mato Grosso. 2014. Tese (Doutorado) - Universidade Estadual Paulista, Araraquara, 2014.

CÔRTES, P. L., TORRENTE, M., ALVES-FILHO, A. P., RUIZ, M. S., DIAS, A. J. G. \& RODRIGUES, R. Crise de abastecimento de água em São Paulo e falta de planejamento estratégico. Estudos Avançados. 29(84), 2015.

COTRIM, M. E.B. Avaliação da qualidade da água na Bacia Hidrográfica do Ribeira de Iguape com vistas ao abastecimento Público. 2006. 250f. Tese (Doutorado) - Instituto de Pesquisas Energéticas e Nucleares, São Paulo, 2006.

DEVESA-REY, R., DIAZ-FIERROZ F., BARRAL, M. T. Trace metals in river bed sediments: An assessment of their partitioning and bioavailability by using multivariate exploratory analysis. Journal of Environmental Management, v.91: p.2471-2477. 2010. 
ESTEVES, F. A. Fundamentos de limnologia. 3a ed. Rio de Janeiro: Interciência, 2011. 826 p.

FERNANDES, H. M. Heavy metal distribution in sediments and ecological risk assessment: the role of diagenetic processes in reducing metal toxicity in bottom sediments. Environmental Pollution, v. 97, n. 3, p. 317-325, 1997.

FIGUEIRÊDO, M.C.B.; TEIXEIRA, A.S.; ARAÚJO, L.F.P.; ROSA, M.F.; PAULINO, W.D.; MOTA, S.; de ARAÚJO, J.C. (2007) Avaliação da vulnerabilidade ambiental dereservatórios à eutrofização. Revista de Engenharia Sanitária e Ambiental, v. 12, n. 4, p. 399-409.

FONTANA, L., ALBUQYERQUE, A. L. S., BRENNER, M., BONOTTO, D. M., SABARIS, T. P. P., PIRES, M. A. F., COTRIM, M. E. B., BICUDO, D. C. The eutrophication history of a tropical water supply reservoir in Brazil. Journal Paleolimnol v. 51:29-43. 2014.

FONTANA, L., Reconstrução paleolimnológica da eutrofização na represa Guarapiranga com base em multitraçadores biogeoquímicos. 2013. 224f. Tese (Doutorado) - Universidade Estadual Paulista, Rio Claro, 2013.

HISAYASU, A.; RIBEIRO, B.; TOLEDO, L. F.; Em menos de 1 ano, surge 32 invasões Às margens de Guarapiranga e Billings. O Estado de São Paulo, São Paulo, 25 Set. 2016. Disponível em:<sao-paulo.estadao.com.br/noticias/geral,emmenos-de-1-ano-surgem-32-invasoes-as-margens-de-guarapiranga-e-

billings,10000078072>. Acesso em 15 de out. 2016.

IBGE. 2015. Cidades. Instituto Brasileiro de Geografia e Estatística. Disponível em:<http://cidades.ibge.gov.br/xtras/uf.php?lang=\&coduf=35\&searcch=saopaulo>. Acessado em 25 de junho de 2016.

ISA. 2006. Seminário do Guarapiranga. Proposição de Ações Prioritárias para Garantir a Água de Boa Qualidade para Abastecimento Público. Legislação na Bacia Hidrográfica da Guarapiranga, 2006. Disponível em: <http://siteantigo.socioambiental.org/inst/sem/guarapiranga2006/docs/legislacao.pdf> Acesso em: 18 de ago. 2014.

KLEEBERG, A. K, A E HUPFER. M. How effectively does a single or continuous iron supply affect the phosphorus budget of aerated lakes. Journal Soils Sediments. 12:1593-1603, 2012.

LAGE, F. Aplicação da tríade de qualidade do sedimento em análises espacial no reservatório Guarapiranga (SP, Brasil). 2013. 118f. Tese (Doutorado) Universidade de São Paulo, São Paulo, 2013.

LEMES, M.J.L. Avaliação de metais e elementos-traço em águas e sedimentos das bacias hidrográficas dos rios Mogiguaçu e Pardo. 2001. 248 f. Dissertação (Mestrado) - Instituto de Pesquisas Enérgeticas e Nucleares, São Paulo, 2001.

LOPES, R. A. Extração sequencial de metais pesados em sedimentos de fundo ao longo do rio Tietê (SP): Participação entre as fases lábil e residual. 2010. 
181 f. Dissertação (Mestrado) - Centro de Energia Nuclear na Agricultura da Universidade de São Paulo, Piracicaba, 2010.

MARTINELLI, L.A., SILVA, A.M., CAMARGO, P.B., MORETTI, L.R., TOMAZELLI, A.C., SILVA, D.M.L., FISCHER, E.G., SONODA, K.C., SALOMÃO, M.S.M.B. Levantamento das cargas orgânicas lançadas nos rios do Estado de São Paulo. Biota Neotrópica, v. 2, 1-18. 2002. Disponível em: < http://www.biotaneotropica.org.br/v2n2/pt/abstract?article+BN01502022002> Acessado em 15 de outubro de 2016.

MATEUS, R.S. Modelo Hidrológico da Bacia Hidrográfica da represa da Guarapiranga - São Paulo (SP). Dissertação de mestrado. Universidade de São Paulo, Faculdade de Filosofia e Ciências Humanas, Programa de Pós-graduação em Geografia Física. 154p. 2006.

MOZETO, A.A. Sedimentos e Particulados Lacustres: Amostragens e Análises Biogeoquímicas. In: Bicudo C.E.M. \& Bicudo, D. C. (Org.). Amostragem em Limnologia. São Carlos: RiMa. p. 295 - 320. 2004.

OKORO, H. K., FATOKI, O. S., ADEKOLA, F. A., XIMBA, B. J.\& SNYMAN, R. G. A review of sequential extraction produceres for heavy metals speciation in soil and sediments. Open Access Scientific Reports. V.1. 3. 2012. Disponível em $<$ https://www.omicsonline.org/scientific-reports/srep181.php> Acessado em 12 de julho de 2016.

OLIVEIRA, R. C. B \& MARINS, R. V. Dinâmica de metais-traço em solo e ambiente sedimentar estuarino como um fator determinante no aporte desses contaminantes para o ambiente aquático: revisão. Revista Virtual de Química, 3 (2) 88-102, 2011.

OTOMO, J. I. Contribuição antrópica na qualidade das águas da represa do Guarapianga. Um estudo sobre interferentes endócrinos. 2015. 216f. Tese (Doutorado) - Instituto de Pesquisas Enérgeticas e Nucleares, São Paulo, 2015.

OWENS, P. N. \& WALLING D. E. Temporal changes in the metal and phosphorus content of suspended sediment transported by Yorkshire rivers, UK over the last 100 years, as recorded by overbank floodplain deposits. Hydrobiologia, v.494, n.13, Mar, p.185-191. 2003.

PADIAL, P. R. Qualidade, heterogeneidade espacial e biodisponibilidade de metais no sedimento de um reservatório tropical urbano eutrofizado (Reservatório Guarapiranga, SP). 2005. 120f. Dissertação (Mestrado) Universidade de São Paulo, São Paulo, 2008.

PASSOS, E. A. Distribuição de sulfeto volatizado em maio ácido e metais pesados em sedimentos do estuário do Rio Sergipe. 2005. 145f. Dissertação (Mestrado) - Universidade Federal de Sergipe, Sergipe, 2005.

PEREIRA, J. C., GUIMARÃES-SILVA, A. K., NALINI-JUNIOR, H. A., PACHECOSILVA, E. \& LENA, J. C. Distribuição, fracionamento e mobilidade de elementos traço em sedimentos superficiais. Química Nova. V. 30(5), p. 1249-1255, 2007. 
POMPEO, M., PADIAL, P. R., MARIANI, C. F., CARDOSO-SILVA, S., MOSCHINICARLOS, V., SILVA, D. C. V. R., PAIVA, T. C. B. \& BRANDIMARTE, A. L. Biodisponibilidade de metais no sedimento de um reservatório tropical urbano (reservatório Guarapiranga - São Paulo (SP), Brasil): há toxicidade potencial e heterogeneidade espacial?. Goechimica Brasiliensis. V. 27(2), p. 104-119, 2013.

PORTO, L. J. L. S, ALMEIDA, C. N., DEZOTTI, M. W. C., CORRÊA, J. A. M., FAIAL, K. C. F. \& FAIAL, K. R. F. Distribuição de metais pesados nos sedimentos de fundo dos rios Caceribu e Guaxindiba, afluentes da Baía de Guanabara - Rio de Janeiro, Brasil. Geochimica Brasiliensis 28(2): 171:188, 2014.

QUEIROZ, W.; OLIVEIRA, A.M.S.; ROSSI, M.; SAAD, A.R.; ANDRADE, M.R.M. Análise geoambiental da bacia do Guarapiranga, Região Metropolitana de São Paulo: produção de sedimentos e assoreamento do reservatório. Revista Brasileira de Geomorfologia. V. 16, n. 1, p. 89-105, 2015.

RICHTER, E. M., FORNARO, A., LAGO, C. L. \& AGNES, L. Evaluation of the chemical composition of the Guarapiranga water system: Case study (2002 and 2003). Quimica Nova, 30(5): 1147-1152, 2007

RODRIGUES, A. S. L, NALINI-JUNIOR, H. A, COSTA, A. T. \& MALAFAIA, G. Construção de mapas geoquímicos a partir de sedimentos ativos de margens oriundos do Rio Gualaxo do Norte, MG, Brasil. Multi-Science Journal. 1(1): 70-78, 2015.

SABESP. COMPANHIA SANEAMENTO BÁSICO DO ESTADO DE SÃO PAULO. DOSSIÊ - Sistema Guarapiranga. Espaço das Águas. São Paulo: Fundação Patrimônio Histórico da Energia 141 e Saneamento Companhia de Saneamento Básico do Estado de São Paulo - SABESP, 2008. Disponível em: < http://memoriasabesp.sabesp.com.br/acervos/dossies/pdf/9_sistema_guarapirang a.pdf> Acessado em 18 de junho de 2016.

SABESP. COMPANHIA SANEAMENTO BÁSICO DO ESTADO DE SÃO PAULO. $2017 . \quad$ Disponível em < http://site.sabesp.com.br/site/interna/Default.aspx?secaold=505> Acessado em 30 de abril de 2017.

SHARAMEL, O., MICHALKE, B., KETTRUP, A. Study of the copper distribution in contaminated soils of hop fields by single and sequential extraction procedures. Science of the Environment, v. 263, p. 11-22. 2000.

SHIHOMATSU, H. M. Desenvolvimento e validação de metodologia SPE-LCMSIMS para a determinação de fármacos e droga de abuso nas águas da represa Guarapiranga-São Paulo/SP, Brasil. 2015. 246f. Tese (Doutorado) Instituto de Pesquisas Energéticas e Nucleares, São Paulo, 2015.

Shiromoto. J, Leitão, J. C. \& Tsutiya, M. T. Operação do Sistema Taquacetuba para a Transferência de Água do Reservatório Billings para Represa Guarapiranga - Região Metropolitana de São Paulo. $23^{\circ}$ Congresso Brasileiro de Engenharia Sanitária e Ambiental, 2005. Disponível em: 
<http://www.bvsde.paho.org/bvsacd/abes23/I-037.pdf>. Acesso em: 22 de julho 2016.

SILVA, J. P. Expansão urbana e evolução geomorfológica em remansos de reservatórios: análise comparativa de duas bacias hidrográficas em Guarapiranga, São Paulo. 2005. 123 f. Dissertação (Mestrado) - Universidade de São Paulo, São Paulo, 2005.

SILVA, D. B. Qualidade de água e sedimento em reservatório. 2016. $174 f$. Dissertação (Mestrado) - Instituto de Pesquisas Energéticas e Nucleares, São Paulo, 2016.

SILVÉRIO, P. F. Bases técnico-científicas para a derivação de valores-guias de qualidade de sedimentos para metais: experimentos de campo e laboratório. 2003. 145f. Tese (Doutorado) - Universidade de São Paulo, São Carlos, 2003.

SOUZA, V. A. Distribuição de metais (Al, Fe, Mn, Cu, Zn Pb e Hg), em sedimentos superficiais do reservatório de Juturnaiba, Rio de Janeiro, Brasil. 2013. 67f. Dissertação (Mestrado) - Universidade Federal Fluminense, Niterói, 2013.

SOUZA, V. L. B, LIMA, V., HAZIN, C. A., FONSECA, C. K. L., SANTOS, S. O. Biodisponibilidade de metais-traço em sedimentos: uma revisão. Brazilian Journal of Radiation Sciences. V.03-01 p. 01-13, 2015.

TEÓDULO, M. J. R.; LIMA, E. S.; NEUMANN, V. H. M. L.; LEITE, P. R. B.; SANTOS, M. L. F. Comparação de métodos de extração parcial de metais traço em solos e sedimentos de um estuário tropical sob a influência de um complexo industrial portuário, Pernambuco Brasil. Estudos Geológicos. V. 13 p. 23-34, 2003.

TESSIER, A.; CAMPBELL, P.G.C.; BISSON, M. Sequential extraction procedure for the speciation of particulate trace metals. Analytical Chemistry, Washington, v. 51, p. 844-851, 1979.

TUNDISI, J. G., Recursos hídricos no futuro: problemas e soluções, Estudos Avançados 22 (63), 2008.

TUNDISI, J. G.; TUNDISI, T. M. Limnologia. In: TUNDISI, J. G.; TUNDISI, T. M. Represas Artificiais. Oficina de Texto. São Paulo, 2008, p. 319-354.

WHATELY, M.; CUNHA, P. M. Guarapiranga 2005 Como e por que São Paulo está perdendo este mancial: resultados do diagnóstico socioambiental participativo da Bacia Hidrográfica do Guarapiranga. ISA - Instituto Socioambiental, 51p. 2006.

ZAGATTO, P. A. \& ARAGÃO, M. A. Avaliação ecotoxicológica do reservatório Guarapiranga, SP, com ênfase ao problema de algas tóxicas. CETESB, São Paulo, 1995. 